\title{
Historical Review of the Transportation Analysis Fact of the Week, 1996-2017
}

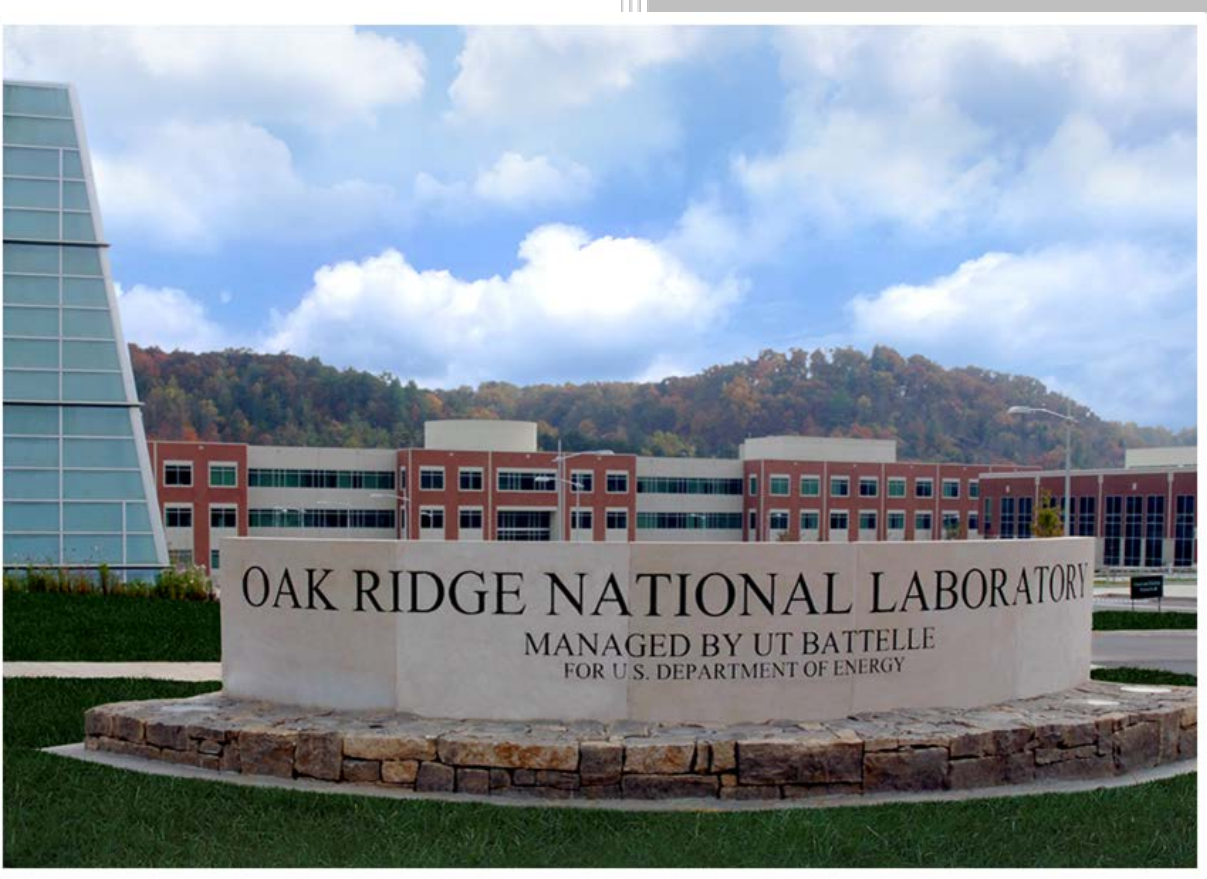

David Gohlke

Stacy Davis

Approved for public release.

Distribution is unlimited. 


\title{
DOCUMENT AVAILABILITY
}

Reports produced after January 1, 1996, are generally available free via US Department of Energy (DOE) SciTech Connect.

\section{Website http://www.osti.gov/scitech/}

Reports produced before January 1, 1996, may be purchased by members of the public from the following source:

\author{
National Technical Information Service \\ 5285 Port Royal Road \\ Springfield, VA 22161 \\ Telephone 703-605-6000 (1-800-553-6847) \\ TDD 703-487-4639 \\ Fax 703-605-6900 \\ E-mail info@ntis.gov \\ Website http://classic.ntis.gov/
}

Reports are available to DOE employees, DOE contractors, Energy Technology Data Exchange representatives, and International Nuclear Information System representatives from the following source:

Office of Scientific and Technical Information

PO Box 62

Oak Ridge, TN 37831

Telephone 865-576-8401

Fax 865-576-5728

E-mail reports@osti.gov

Website http://www.osti.gov/contact.html

This report was prepared as an account of work sponsored by an agency of the United States Government. Neither the United States Government nor any agency thereof, nor any of their employees, makes any warranty, express or implied, or assumes any legal liability or responsibility for the accuracy, completeness, or usefulness of any information, apparatus, product, or process disclosed, or represents that its use would not infringe privately owned rights. Reference herein to any specific commercial product, process, or service by trade name, trademark, manufacturer, or otherwise, does not necessarily constitute or imply its endorsement, recommendation, or favoring by the United States Government or any agency thereof. The views and opinions of authors expressed herein do not necessarily state or reflect those of the United States Government or any agency thereof. 
Energy and Transportation Science Division

\title{
HISTORICAL REVIEW OF THE TRANSPORTATION ANALYSIS FACT OF THE WEEK, 1996-2017
}

\author{
David Gohlke \\ AAAS Science and Technology Policy Fellow, \\ Vehicle Technologies Office \\ U.S. Department of Energy \\ (currently with Argonne National Laboratory) \\ Stacy Davis \\ Energy and Transportation Science Division \\ Oak Ridge National Laboratory
}

October 2017

Prepared by

OAK RIDGE NATIONAL LABORATORY

Oak Ridge, TN 37831-6283

managed by

UT-BATTELLE, LLC

for the

US DEPARTMENT OF ENERGY

under contract DE-AC05-00OR22725 
(This page intentionally left blank) 


\section{Abstract}

The Vehicle Technologies Office in the United States Department of Energy hosts a transportation analysis fact of the week on its webpage. As of October 2017, one thousand facts have been published since 1996. Examining the themes of published facts allows one to trace analytical trends determined to be of interest to the public over this time. The most popular themes addressed in the Fact of the Week were vehicle fuel economy, petroleum use and production, vehicle sales, and traveler behavior. Facts on vehicle electrification and advanced combustion technologies have been more popular in the last few years, showing their relevance to the Department of Energy mission.

\section{Acknowledgments}

This activity was supported by the Vehicle Technologies Office, Office of Energy Efficiency and Renewable Energy, United States Department of Energy and through a AAAS Science \& Technology Policy Fellowship served at the Vehicle Technologies Office.

This report was prepared as an account of work sponsored by an agency of the United States government. Neither the United States government nor any agency thereof, nor any of their employees, makes any warranty, express or implied, or assumes any legal liability or responsibility for the accuracy, completeness, or usefulness of any information, apparatus, product, or process disclosed or represents that its use would not infringe privately owned rights. Reference herein to any specific commercial product, process, or service by trade name, trademark, manufacturer, or otherwise does not necessarily constitute or imply its endorsement, recommendation, or favoring by the United States government or any agency thereof. The views and opinions of authors expressed herein do not necessarily state or reflect those of the United States government or any agency thereof.

\section{List of Acronyms}

$\begin{array}{ll}\text { AEO } & \text { Annual Energy Outlook } \\ \text { DOE } & \text { Department of Energy } \\ \text { EIA } & \text { Energy Information Administration } \\ \text { EERE } & \text { Office of Energy Efficiency and Renewable Energy } \\ \text { EV } & \text { electric vehicle } \\ \text { FotW } & \text { Fact of the Week } \\ \text { ICE } & \text { internal combustion engine } \\ \text { GDP } & \text { gross domestic product } \\ \text { HDV } & \text { heavy-duty vehicle } \\ \text { HEV } & \text { hybrid electric vehicle } \\ \text { VMT } & \text { vehicle miles traveled } \\ \text { VTO } & \text { Vehicle Technologies Office }\end{array}$




\section{Table of Contents}

Abstract

Acknowledgments $\quad v$

List of Acronyms $\quad v$

Table of Contents $\quad$ vi

List of Figures $\quad$ vii

List of Tables $\quad$ vii

1. Introduction and History $\quad 1$

2. Topics of Interest 2

3. Historical Trends for Different Themes

Fact Comparison \#1 - Most Common Themes 5

Fact Comparison \#2 - Fuel Economy and Related Topics $\quad 6$

Fact Comparison \#3 - Traditional Powertrains and Fuels $\quad 7$

Fact Comparison \#4 - Alternative Powertrains and Fuels 8

Fact Comparison \#5 - Economic Factors 8

Fact Comparison \#6 - Ownership and Infrastructure $\quad 9$

4. Geographic and Temporal Scope 10

Trends and Snapshots $\quad 10$

Geographic Scope $\quad 10$

5. Miscellenaeous Trends in the Fact of the Week 12

Appendix A: Description of Specific Fact of the Week Topics 15

Comparison of petroleum production and transportation petroleum consumption - FotW \#1000 15

Historical average gasoline price - FotW \#985

Trends of vehicle fuel economy, vehicle weight, and performance - FotW \#969 17

Energy used by different modes of transportation - FotW \#953 18

Importance to consumers of fuel economy when purchasing a vehicle - FotW \#942 19

Appendix B: Complete List of Facts of the Week 20

References $\quad 32$ 


\section{List of Figures}

Figure 1. Number of iterations for each original fact of the week 2

Figure 2. Frequency of clusters of facts on the same theme $\quad 4$

Figure 3. Historical trend for facts on vehicle lightweighting, tires, and aerodynamic drag 5

Figure 4. Historical trend for the most common Facts of the Week 6

Figure 5. Historical trend for facts on fuel economy, emissions, energy, and policy 27

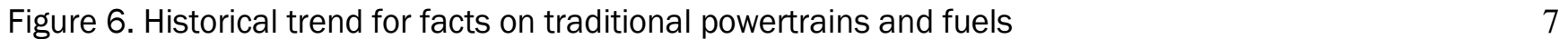

Figure 7. Historical trend for facts on alternative powertrains and fuels 8

Figure 8. Historical trend for facts on economic factors 9

Figure 9. Historical trend for facts on vehicle ownership and infrastructure 9

Figure 10. Temporal scope of Facts of the Week 10

Figure 11. Geographic scope of Facts of the Week 11

Figure 12. Temporal and geographic scopes of first 1000 Facts of the Week 11

Figure 13. Gap between repeated facts on the same topic $r$

Figure 14. Gap (in days) between publication of consecutive Facts of the Week 13

Figure 15. Number of words in the title of each Fact of the Week 13

Figure 16. Word cloud for most commonly used words in Fact of the Week titles 14

Figure 17. U.S. petroleum production and consumption, FotW \#1000 (DOE, 2017c) 15

Figure 18. Annual gasoline pump price, FotW \#985 (DOE, 2017a) 16

Figure 19. Characteristics of new light vehicles, FotW \#969 (DOE, 2017b) 17

Figure 20. Transportation energy use by mode and fuel type, FotW \#953 (DOE, 2016b) 18

Figure 21. Survey responses for most important vehicle attribute, FotW \#942 (DOE, 2016a) 19

\section{List of Tables}

Table 1. Topics of the Most Repeated Facts of the Week 3

Table 2. List of Every Transportation Analysis Fact of the Week 20 
(This page intentionally left blank) 


\section{Introduction and History}

The Vehicle Technologies Office (VTO) in the Office of Energy Efficiency and Renewable Energy (EERE) in the U.S. Department of Energy (DOE) has the mission to reduce petroleum consumption through research and development of new technologies, testing and analysis, government and community stakeholder support, and education. Achieving this goal will strengthen national security, stimulate economic growth, increase affordability of transportation, and improve energy reliability and resiliency. The Transportation Analysis Fact of the Week (FotW) is an outward-facing communication tool on the VTO website used to share interesting analytic results with the public. The typical format for these facts posted online includes a graphic and a textual description, and inclusion of supporting data and references. Topics are broadly related to vehicles, transportation, energy usage, and fuel consumption.

The first Transportation Analysis Fact of the Week was published on July 12, 1996 as a means of highlighting data trends for the DOE Office of Transportation Technologies staff (predecessor office to VTO) and the transportation community at large. The first Fact of the Week was titled "Increase in Annual Light Vehicle Sales 1980-1995”. Since then, one thousand Facts of the Week have been published online; the $1000^{\text {th }}$ Fact of the Week was published on October 23, 2017 - "U.S. Petroleum Production Met Demand from Transportation Petroleum Consumption in 2015”. From 1996 to 2002, these facts were posted online by the Office of Transportation Technologies at http://www.ott.doe.gov/facts/, from 2003 to 2008, these facts were posted online at http://www1.eere.energy.gov/vehiclesandfuels/facts/ by the Vehicle Technologies Office, and since 2009, the facts have been posted at https://energy.gov/eere/vehicles/transportation-fact-week (DOE, 2017d). Facts published before 2009 are no longer available on the Department of Energy webpage, but can be accessed online through archive.org (Internet Archive, 2017). The Fact of the Week has been published regularly; since shifting to being hosted on the EERE webpage in 2003, there have been only five temporary breaks in publication (see Figure 14 in Section 5 for greater detail).

The Facts of the Week have a large and diverse audience. From October 2016 through September 2017, there were over 160,000 page views. More than half (52\%) of new visitors to the VTO web page come through the Fact of the Week. For more regular visitors, a newsletter subscription has been made available via a voluntary distribution list; this newsletter has over 7,800 subscribers.

Section 1 of this report gives an introduction to the Fact of the Week and historical context. Section 2 looks at specific topics of interest that have been frequently revisited. Section 3 examines the historical trends of different economic, technological, and environmental themes. In particular, the number of facts published on different powertrains and fuels is compared, showing which themes have been of the greatest analytical interest at different times. Section 4 addresses the geographic and temporal scope of each Fact of the Week. Section 5 compares other miscellaneous meta-trends in the Facts of the Week. Appendix A explores five specific topics which have been frequently republished in depth. Appendix B gives a comprehensive list of all 1000 Facts of the Week. 


\section{Topics of Interest}

The Facts of the Week address many topics of interest to the Department of Energy, the Vehicle Technologies Office, and the broader transportation community. These topics are directly related to fuel economy, vehicle technology, and cost to the consumer.

New topics are frequently explored in the Fact of the Week, though certain topics have been presented as facts multiple times. Facts are often repeated when updated data are available, with many updated on an annual or biennial basis. In total, updates of previous facts make up $37 \%$ of the 1000 total published facts through 2017. ${ }^{1}$ Figure 1 illustrates how often each Fact of the Week topic has been reused. The $\mathrm{x}$-axis represents the original fact number, and the y-axis shows each repetition. For example, FotW \#355 compares historical prices for gasoline, diesel, and several alternative fuels; this topic has been re-used a total of six times, as shown in the figure. The topics that have been revisited most often were generally first published early in the history of the Fact of the Week and have had continued updates with the newest available data.

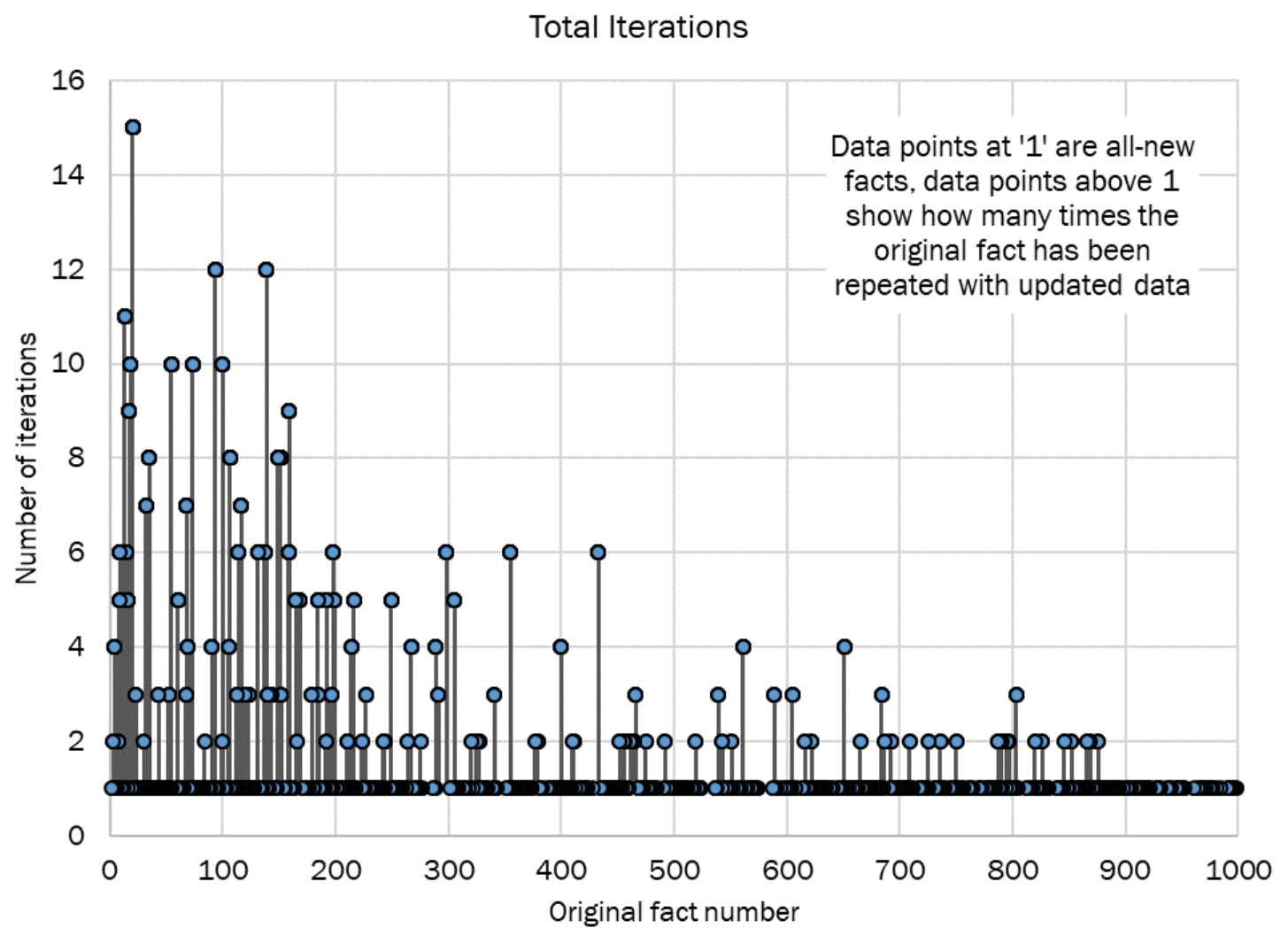

Figure 1. Number of iterations for each original fact of the week

Table 1 details the seventeen different themes from Figure 1 that have been repeated in similar format at least seven times each. Combined, these seventeen themes have been presented as Facts of the Week 161 times. These facts are some of the most popular; the historical price of gasoline is the most visited Fact of the Week from external web searches, with nearly 100,000 visits from October 1, 2016 to September 30, 2017.

\footnotetext{
${ }^{1}$ There have been 633 unique topics published as Facts of the Week, and 124 of these topics have been updated with the latest data and published again.
} 
Table 1. Topics of the Most Repeated Facts of the Week

\begin{tabular}{|c|}
\hline Theme \\
\hline $\begin{array}{l}\text { Importance of fuel economy when } \\
\text { purchasing a vehicle }\end{array}$ \\
\hline $\begin{array}{l}\text { Sales of light-duty diesel vehicles in } \\
\text { Western Europe }\end{array}$ \\
\hline $\begin{array}{l}\text { Historic vehicle ownership rates in United } \\
\text { States and internationally }\end{array}$ \\
\hline $\begin{array}{c}\text { World oil reserves, production, and } \\
\text { consumption }\end{array}$ \\
\hline Historical average gasoline pump price \\
\hline Light-duty vehicle sales in United States \\
\hline $\begin{array}{l}\text { Comparison of petroleum production and } \\
\text { transportation petroleum consumption }\end{array}$ \\
\hline Market share of cars and light trucks \\
\hline Petroleum portion of total trade deficit \\
\hline $\begin{array}{c}\text { Comparison of vehicle miles traveled and } \\
\text { the price of gasoline }\end{array}$ \\
\hline $\begin{array}{l}\text { Worldwide production and sales of light- } \\
\text { duty vehicles }\end{array}$ \\
\hline Number of gasoline refueling stations \\
\hline $\begin{array}{l}\text { Trends of vehicle fuel economy, vehicle } \\
\text { weight, and performance }\end{array}$ \\
\hline $\begin{array}{l}\text { Historical improvements in fuel economy } \\
\text { across U.S. vehicle fleet }\end{array}$ \\
\hline Average price of new light-duty vehicles \\
\hline $\begin{array}{l}\text { Public opinion surveys about fuels which } \\
\text { could replace gasoline }\end{array}$ \\
\hline
\end{tabular}

\begin{tabular}{|c|}
\hline First publication \\
\hline $\begin{array}{c}\text { \#20 } \\
\text { (February 24, 1997) }\end{array}$ \\
\hline $\begin{array}{c}\text { \#93 } \\
\text { (June 15, 1999) }\end{array}$ \\
\hline $\begin{array}{c}\text { \#139 } \\
\text { (August 7, 2000) }\end{array}$ \\
\hline $\begin{array}{c}\text { \#13 } \\
\text { (December 2, 1996) }\end{array}$ \\
\hline $\begin{array}{c}\# 18 \\
\text { (February 10, 1997) }\end{array}$ \\
\hline $\begin{array}{c}\text { \#54 } \\
\text { (February 2, 1998) }\end{array}$ \\
\hline $\begin{array}{c}\# 73 \\
\text { (January 11, 1999) }\end{array}$ \\
\hline $\begin{array}{c}\# 100 \\
\text { (September 29, 1999) }\end{array}$ \\
\hline $\begin{array}{c}\text { \#17 } \\
\text { (February 3, 1997) }\end{array}$ \\
\hline $\begin{array}{c}\# 159 \\
(\text { March 19, 2001) }\end{array}$ \\
\hline $\begin{array}{c}\text { \#35 } \\
\text { (June 30, 1997) }\end{array}$ \\
\hline $\begin{array}{c}\# 106 \\
\text { (November 22, 1999) }\end{array}$ \\
\hline $\begin{array}{c}\# 149 \\
\text { (November 27, 2000) }\end{array}$ \\
\hline $\begin{array}{c}\# 151 \\
\text { (January 1, 2001) }\end{array}$ \\
\hline $\begin{array}{c}\text { \#32 } \\
\text { (June 11, 1997) }\end{array}$ \\
\hline $\begin{array}{c}\text { \#68 } \\
\text { (September 23, 1998) }\end{array}$ \\
\hline $\begin{array}{c}\text { \#116 } \\
\text { (February 14, 2001) }\end{array}$ \\
\hline
\end{tabular}

\begin{tabular}{|c|c|}
\hline Most recent publication & Frequency \\
\hline $\begin{array}{c}\text { \#942 } \\
\text { (September 12, 2016) }\end{array}$ & 15 \\
\hline $\begin{array}{c}\text { \#716 } \\
\text { (February 27, 2012) }\end{array}$ & 12 \\
\hline $\begin{array}{c}\text { \#962 } \\
\text { (January 30, 2017) }\end{array}$ & 12 \\
\hline $\begin{array}{c}\# 578 \\
\text { (July 6, 2009) }\end{array}$ & 11 \\
\hline $\begin{array}{c}\# 985 \\
\text { (July 10, 2017) }\end{array}$ & 10 \\
\hline $\begin{array}{c}\# 959 \\
\text { (January 9, 2017) }\end{array}$ & 10 \\
\hline $\begin{array}{c}\# 1000 \\
\text { (October 23, 2017) }\end{array}$ & 10 \\
\hline $\begin{array}{c}\text { \#956 } \\
\text { (December 19, 2016) }\end{array}$ & 10 \\
\hline $\begin{array}{c}\text { \#593 } \\
\text { (October 19, 2009) }\end{array}$ & 9 \\
\hline $\begin{array}{c}\# 906 \\
\text { (January 4, 2016) }\end{array}$ & 9 \\
\hline $\begin{array}{c}\# 972 \\
\text { (April 10, 2017) }\end{array}$ & 8 \\
\hline $\begin{array}{c}\# 782 \\
\text { (June 3, 2013) }\end{array}$ & 8 \\
\hline $\begin{array}{c}\text { \#969 } \\
\text { (March 20, 2017) }\end{array}$ & 8 \\
\hline $\begin{array}{c}\text { \#955 } \\
\text { (December 12, 2016) }\end{array}$ & 8 \\
\hline $\begin{array}{c}\# 988 \\
\text { (July 31, 2017) }\end{array}$ & 7 \\
\hline $\begin{array}{c}\# 944 \\
\text { (September 26, 2016) }\end{array}$ & 7 \\
\hline $\begin{array}{c}\text { \#810 } \\
\text { (December 30, 2013) }\end{array}$ & 7 \\
\hline
\end{tabular}

To allow a deeper dive into various aspects of a single topic, facts are often published in so-called "clusters" of related facts over consecutive weeks. Frequently, two to four facts of the same theme, or from the same source, are published together. Since 2011, the average number of facts in each cluster has grown, showing the shift toward deeper analysis in the Fact of the Week. In Figure 2, each dot represents a single cluster; many of the dots have a value of one, representing an isolated fact, though these are less common than they used to be. The size of clusters of facts over time is growing, especially since 2011. The most consecutive facts on a single theme (8) detailed results from an opinion survey done in 2004 which described people's views on energy-efficient vehicle technologies. Some of the other largest clusters are highlighted in Figure 2. 


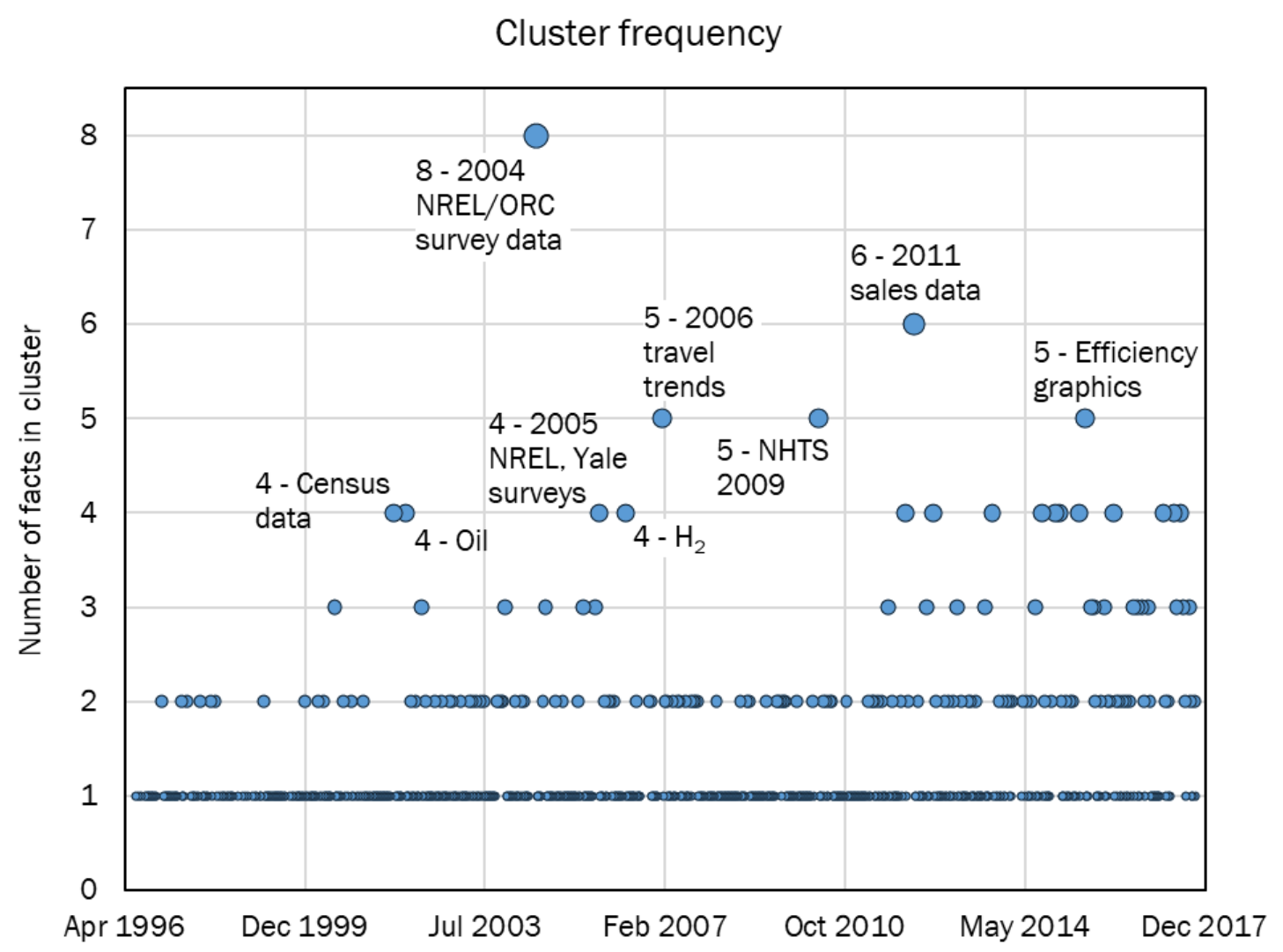

Figure 2. Frequency of clusters of facts on the same theme

The trends of which facts have been published show different topics that have been of interest. For instance, the second-most repeated fact has been about the sale of diesel automobiles in Europe. These vehicles are now very prominent in the European market, having nearly doubled since FotW \#93 started tracking diesel sales of passenger cars in 1999. This growth corresponds with frequent publication on the topic, and one can follow the growth trend throughout different countries in Europe using the Fact of the Week. However, after the share of diesel sales reached its maximum in 2011 (ACEA, 2017), this fact has not been updated. 


\section{Historical Trends for Different Themes}

In addition to Facts of the Week on specific topics, broader themes are explored. The historical trends of each of these themes can be studied by noting what themes are present in each fact. The themes are not exclusive; e.g., a fact assessing alternative fuels will be marked for each of the fuels compared, and a fact about fuel economy may also be on combustion and the cost to the consumer. Trends in these facts correlate with research focuses of DOE and interesting trends outside of DOE.

As an illustrative example, Figure 3 represents the Facts of the Week examining energy losses from driving resistance, specifically pertaining to vehicle lightweighting, aerodynamic drag, and tires/rolling friction. Each vertical black line segment represents a single fact that was published on this theme, while the horizontal orange lines represent the cumulative number of facts on the theme. FotW \#980-983 comprised a cluster on fuel economy for typical driving, which is shown in this figure as a steep increase in the upper right.

FotW on lightweighting, tires, and air resistance

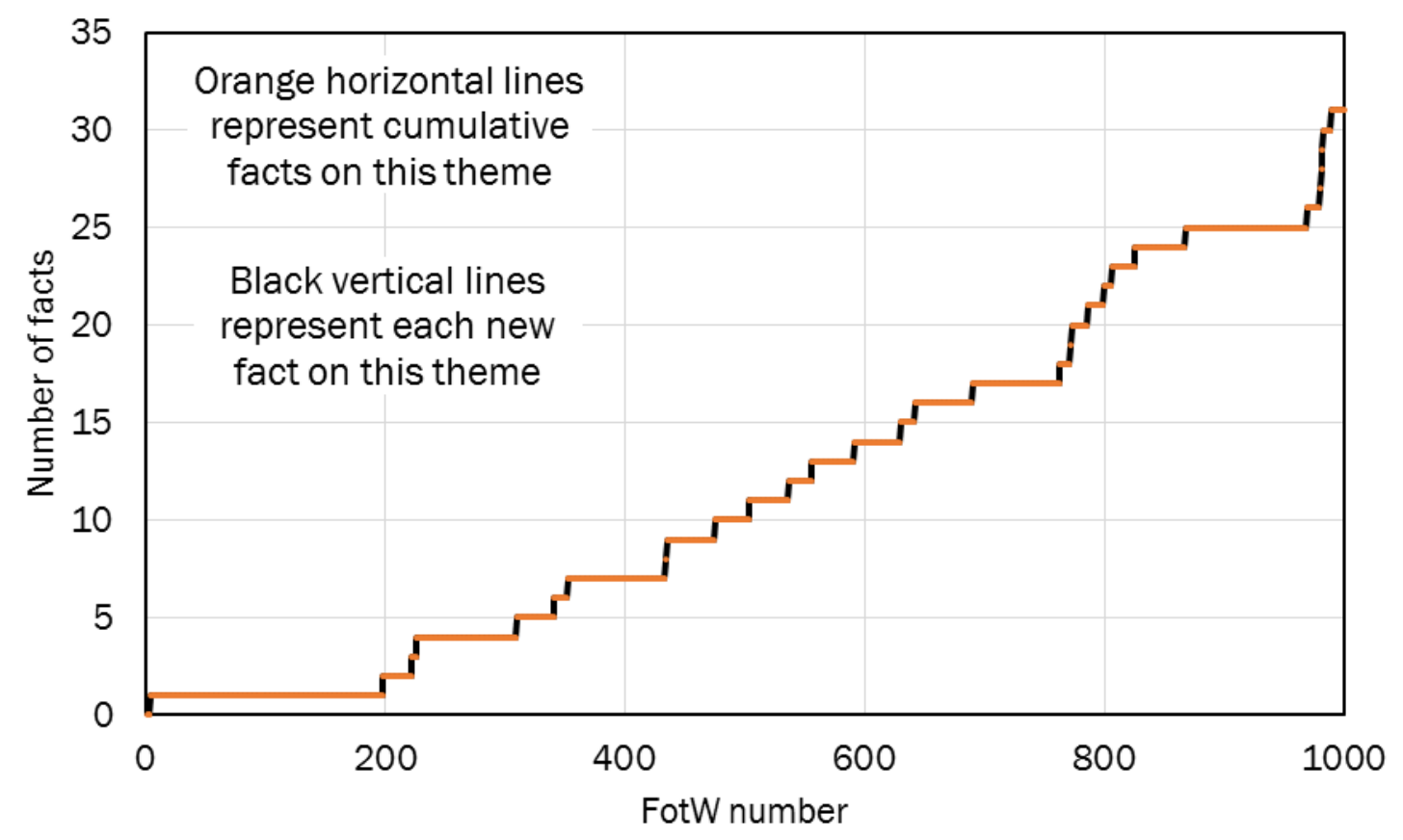

Figure 3. Historical trend for facts on vehicle lightweighting, tires, and aerodynamic drag

The following subsections address several of these themes in greater detail. Figures 4-9 display overall trends in the Facts of the Week, showing cumulative number of facts published over time, graphed in the same manner as Figure 3.

\section{Fact Comparison \#1 - Most Common Themes}

Figure 4 shows the most popular themes addressed in the Fact of the Week, namely vehicle fuel economy, petroleum use and production, vehicle sales, and traveler behavior. Vehicle sales (e.g., number of sales per year) and petroleum (e.g., price of crude oil) are the most common, and have been highlighted in 15\% and $13 \%$ of all facts, respectively. Fuel economy and travel behavior have also been examined in over $10 \%$ of the facts. 


\section{FOTW trends}

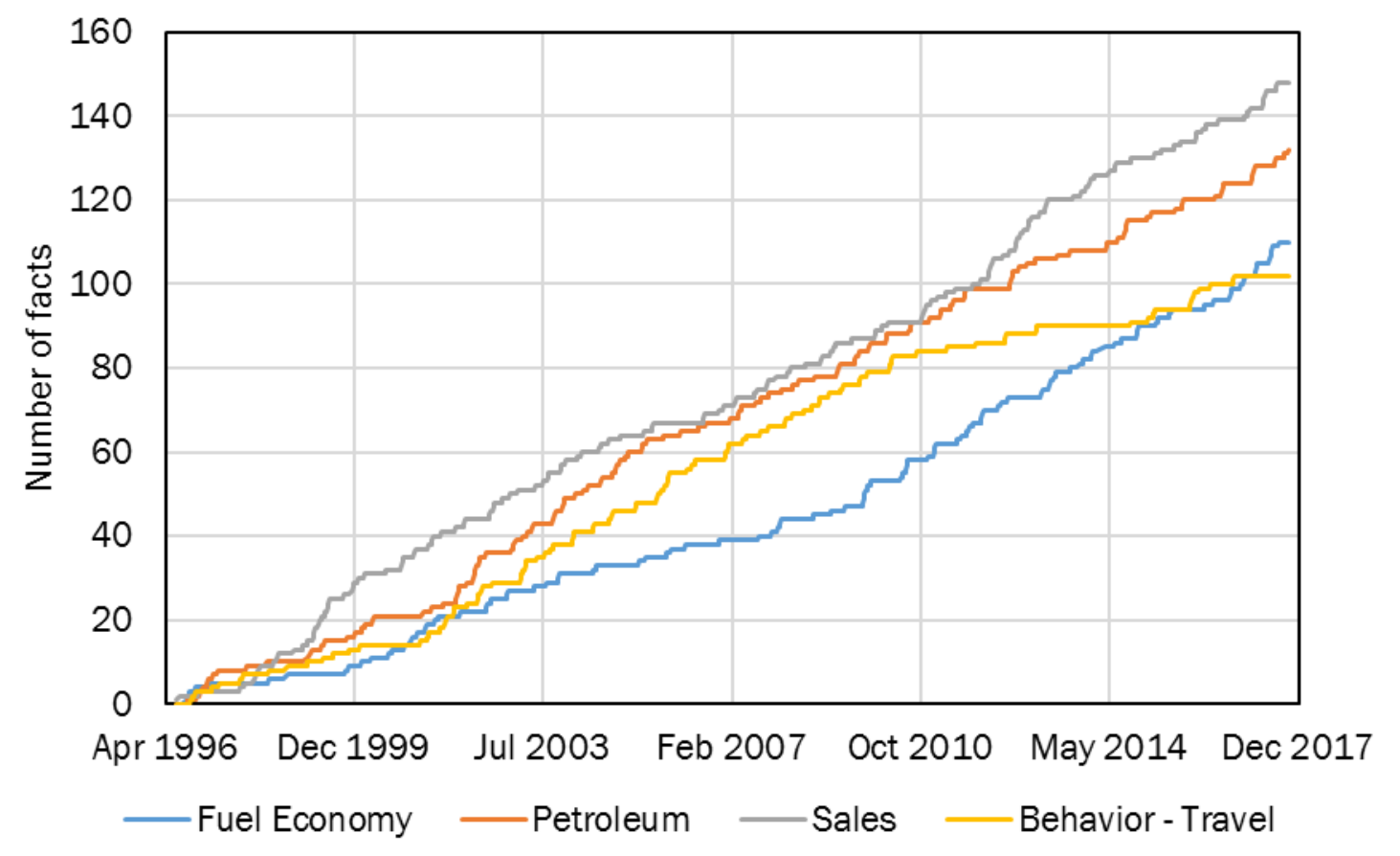

Figure 4. Historical trend for the most common Facts of the Week

Through the decade of the 2000s, facts related to traveler behavior were more frequent (e.g., vehicle miles of travel (VMT) and commute patterns), while in the 2010s, facts related to fuel economy were more frequent (e.g., fuel economy of new vehicles and fuel consumption at different speeds). These Facts of the Week corresponded with changes in behavior and policy external to DOE. From 2000 to 2007 total VMT increased 8\%, though VMT did not reach this level again until 2015 (FHWA, 2017). In 2009, new federal fuel economy and greenhouse gas regulations were introduced, and fuel economy reached an all-time high (EPA, 2016).

\section{Fact Comparison \#2 - Fuel Economy and Related Topics}

Figure 5 shows the cumulative number of facts on fuel economy, emissions, energy, and policy. Many facts in these themes are related' for example, "NHTSA and EPA Finalized Medium and Heavy Truck Fuel Efficiency and Greenhouse Gas Standards through Model Year 2027” is related to fuel economy, emissions, and policy. As noted above, facts related to fuel economy increased as regulations were made more stringent, and facts related to emissions and regulations increased as well. Facts across the broader energy sector have also increased recently, along with the growth in vehicles powered by electricity and natural gas, two fuels with strong historical links outside the transportation sector. 


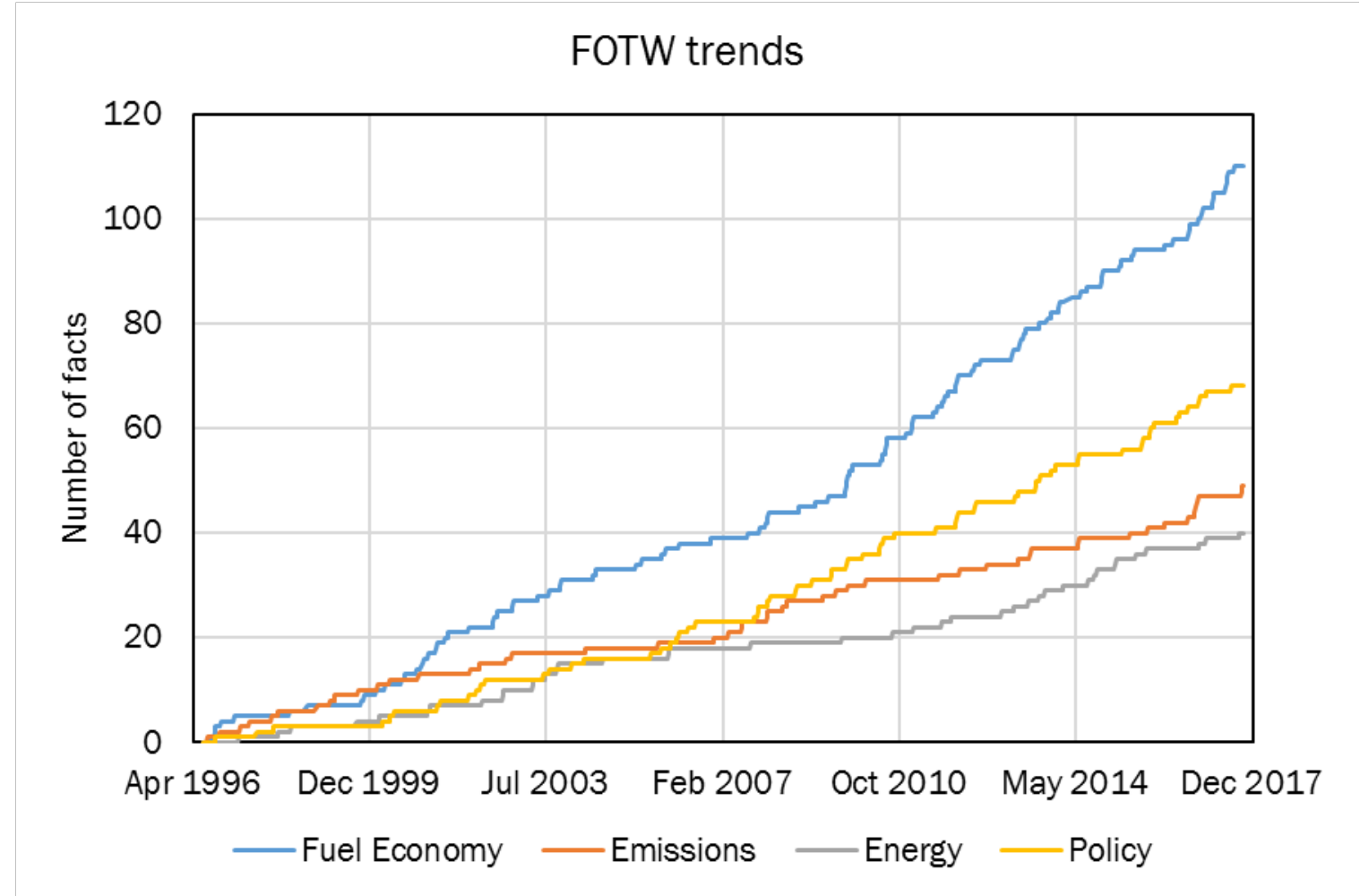

Figure 5. Historical trend for facts on fuel economy, emissions, energy, and policy

\section{Fact Comparison \#3 - Traditional Powertrains and Fuels}

Diesel and gasoline are traditional fuels for internal combustion engines (ICE). Figure 6 explores the publication of facts related to these petroleum-based fuels. The growth in facts related to combustion in the 2010s is due to the increased focus on advanced technologies to improve fuel economy. Facts on heavy-duty vehicles (HDV) are included here due to their common use of diesel fuel in ICEs.

\section{FOTW trends}

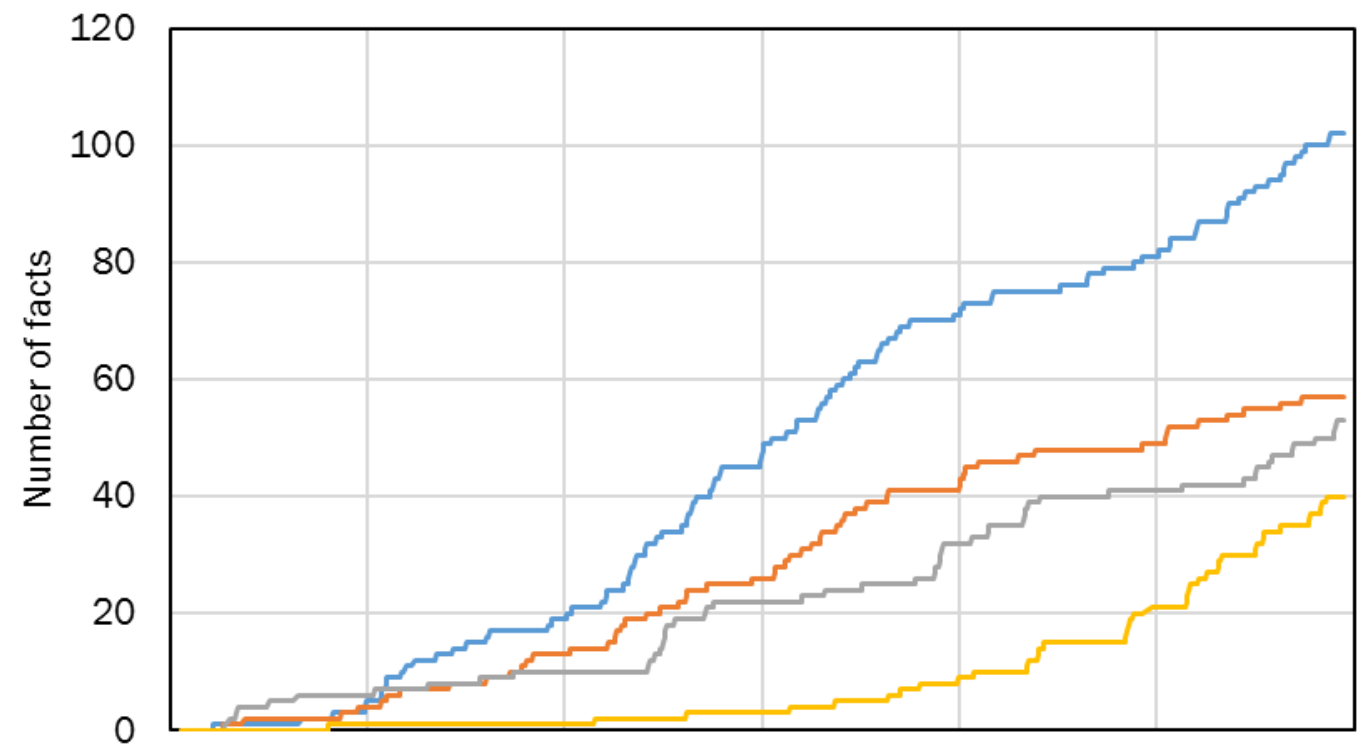

Apr 1996 Dec 1999 Jul 2003 Feb 2007 Oct 2010 May 2014 Dec 2017 - Gasoline - Diesel — HDV Combustion

Figure 6. Historical trend for facts on traditional powertrains and fuels 
Facts of the Week on gasoline are particularly sensitive to the price of gasoline at the pump. As shown in FotW \#985 (DOE, 2017a), gasoline prices were at a historic low in the late 1990s, corresponding to fewer facts on this theme. As gas prices rose in 2000, more facts were published on this theme. Steady gasoline prices in 2001 and 2002 led to fewer facts on fuel prices, but the rapid increase in fuel prices from 2003 to 2008 corresponded with an increase in the number of facts on this theme. Likewise, facts related to diesel fuel rose due both to its increase in price and its potential for greater fuel economy.

\section{Fact Comparison \#4 - Alternative Powertrains and Fuels}

Figure 7 shows the historical trend for facts from advanced technology powertrains and fuels: electric vehicles (EV), hybrid electric vehicles (HEV), biofuels, and hydrogen. Advanced research at the U.S. Department of Energy on biofuels and hydrogen is being supported by the Bioenergy Technologies Office and the Fuel Cells Technologies Office, respectively, while work on hybrid and electric powertrains has been supported by the Vehicle Technologies Office. HEV facts grew rapidly in the early 2000s. During that same timeframe, total sales of HEVs grew from under 10,000 in 2000 to over 350,000 in 2007. Since then more facts have been published on EVs, corresponding to the growth in sales of mainstream electric vehicles.

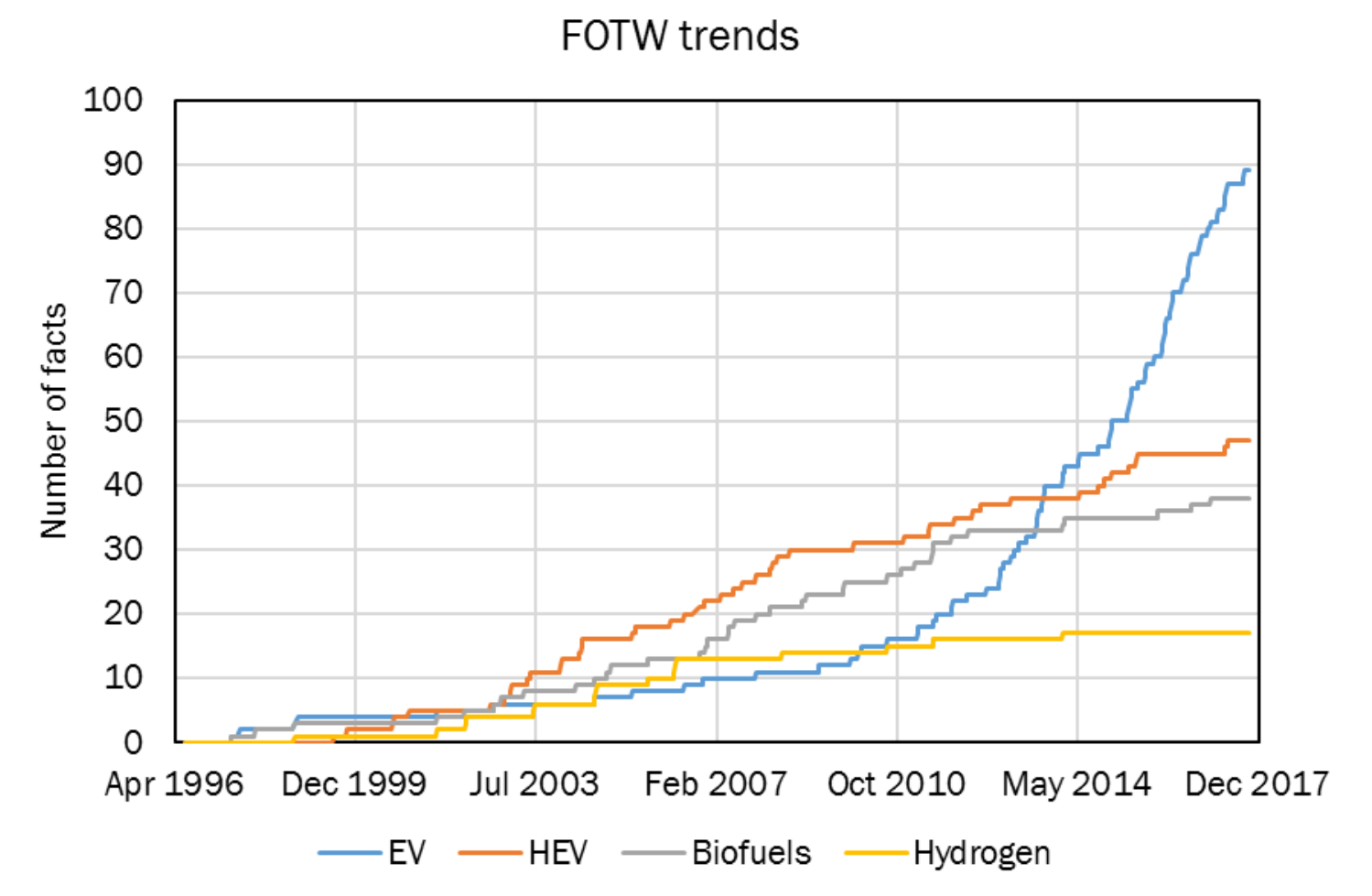

Figure 7. Historical trend for facts on alternative powertrains and fuels

\section{Fact Comparison \#5 - Economic Factors}

Economic facts are highlighted in Figure 8. The cost to the end-user has always been important, with over $8 \%$ of the facts on this theme. The Fact of the Week has recently made a concerted effort to include facts which can be relevant to a broad public audience, with fourteen facts on consumer cost since late-2016, spanning fuel economy suggestions, vehicle sales data, and electric vehicle charging facts.

Since the recession in 2008, facts about manufacturing have been more popular, addressing vehicle production and the related employment impacts. Macroeconomics includes such topics as gross domestic product (GDP) and sector-wide employment. Many of the facts on imports and exports are related to international petroleum markets, though vehicle sales and manufacturing are also included in this theme. 


\section{FOTW trends}

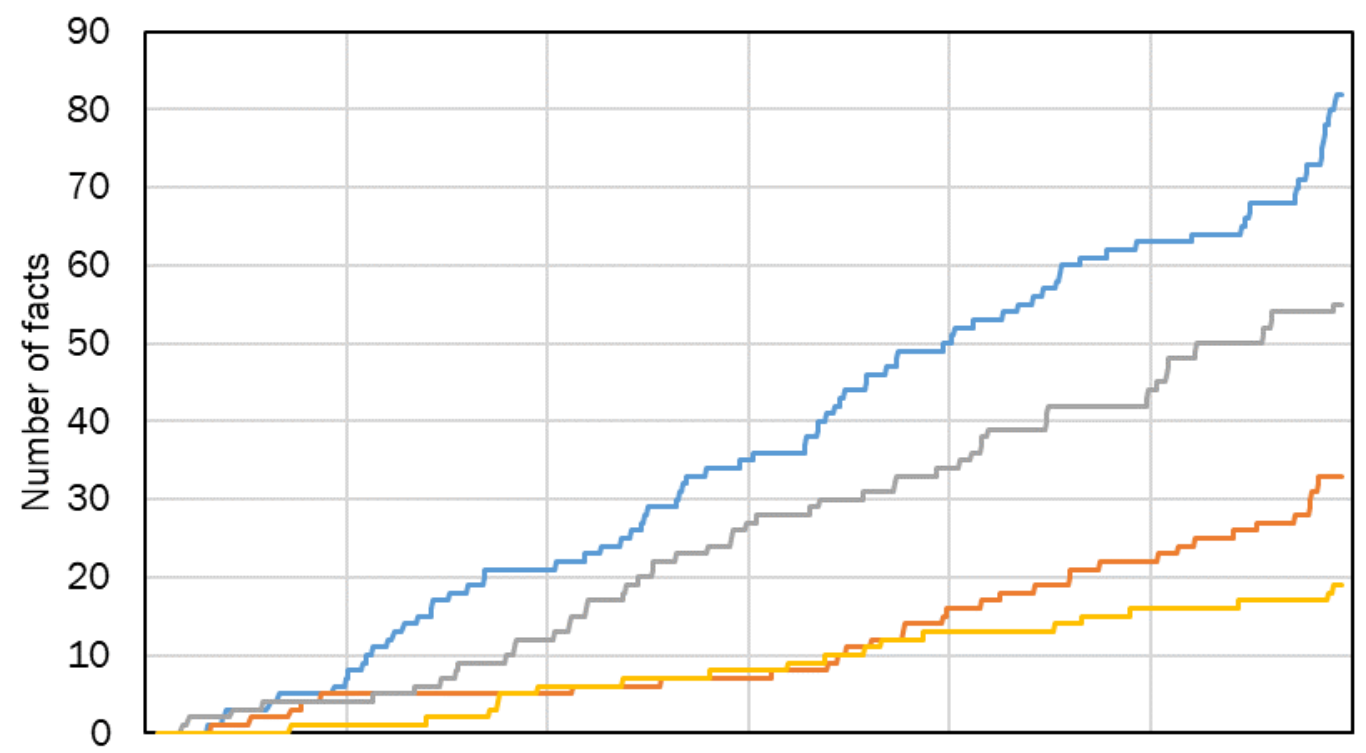

Apr 1996 Dec 1999 Jul 2003 Feb 2007 Oct 2010 May 2014 Dec 2017

—Consumer Cost —-Manufacturing —-Import/Export —-Macroeconomics

Figure 8. Historical trend for facts on economic factors

\section{Fact Comparison \#6 - Ownership and Infrastructure}

Figure 9 shows the trends of facts related to vehicle ownership and infrastructure availability. Facts describing vehicle ownership have been reduced in prominence, while facts related to infrastructure (including gas stations, electric vehicle charging, and the roadway network) have become more prominent.

\section{FOTW trends}

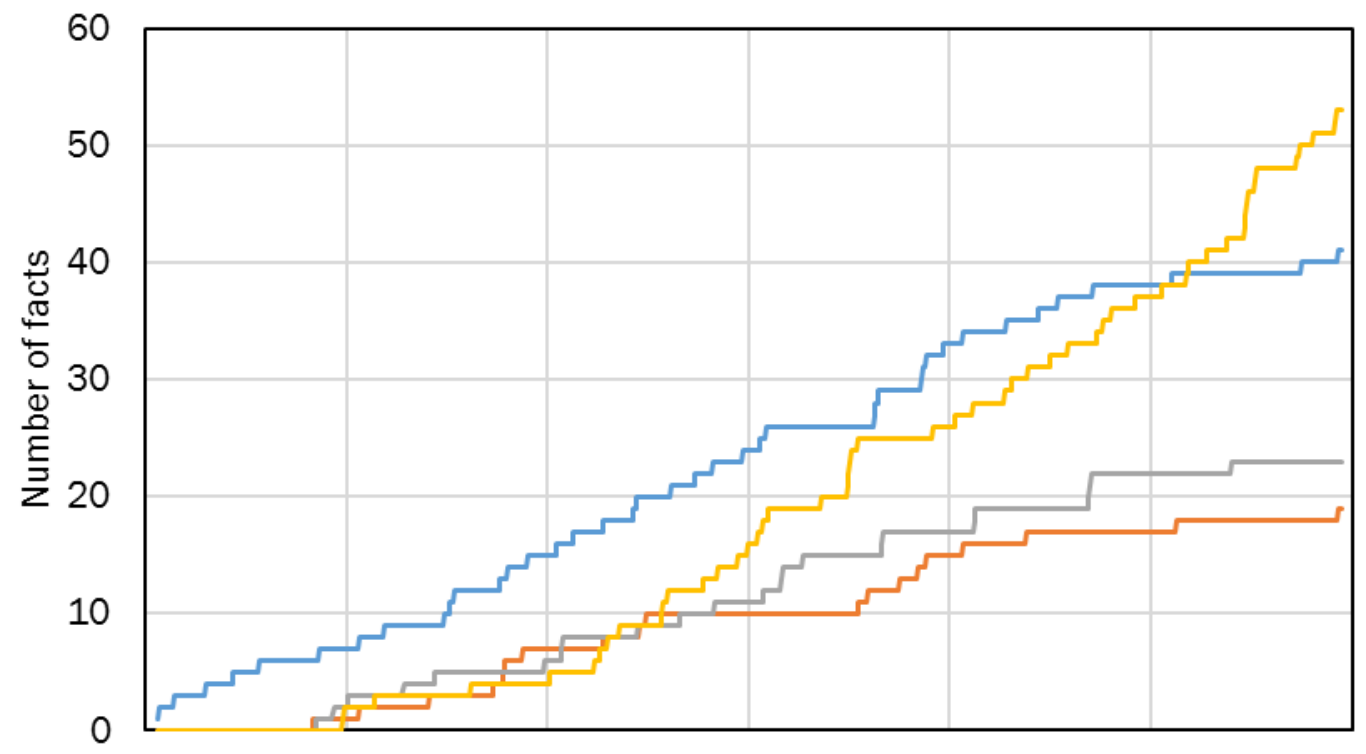

Apr 1996 Dec 1999 Jul 2003 Feb 2007 Oct 2010 May 2014 Dec 2017 — Behavior - Ownership — Fleet Age —Congestion —-Infrastructure

Figure 9. Historical trend for facts on vehicle ownership and infrastructure 


\section{Geographic and Temporal Scope}

This section compares variations in the spatial and temporal scope of Facts of the Week, beyond the broader themes explored in Section 3. The majority of the Facts of the Week present specific data about transportation and energy, but length- and time-scales are important to contextualize the results. In a geographic sense, these facts could address data at a national level or a state level. Similarly, a fact could be presented as a deep dive for a single moment in time, or as a trend, comparing changes as time progresses.

\section{Trends and Snapshots}

Figure 10 shows both facts that show a snapshot of a statistic in time as well as those which compare a trend. Through FotW \#1000, 53\% of facts have compared and contrasted data between years, and 34\% of facts have examined a single point in time. Atemporal facts, which are explanatory but are not based on real-world measurement, comprise most of the remainder of the facts. This includes facts explaining a technical concept or describing future policy standards.

\section{FOTW temporal scope}

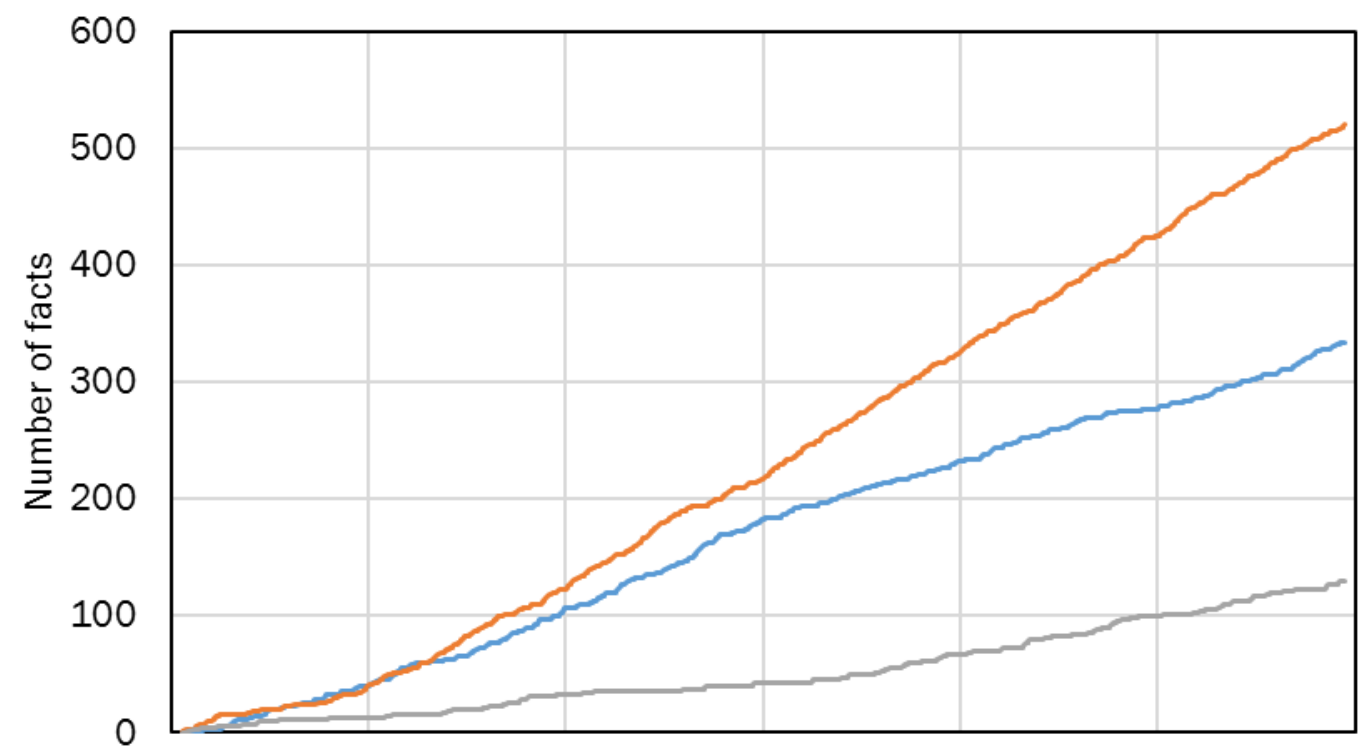

Apr 1996 Dec 1999 Jul 2003 Feb 2007 Oct 2010 May 2014 Dec 2017

- Snapshot - Trend -Atemporal

Figure 10. Temporal scope of Facts of the Week

Through 2000 (FotW \#150), the numbers of facts with a trend and with a single snapshot were even, but since then, facts showing trends have been more common. After 2006, facts analyzing a single fixed time became somewhat less common, shown as a slight bend in the curve in Figure 10. Often within a cluster, one fact will be published with a snapshot, while a second fact will examine the variation in the trend over time.

\section{Geographic Scope}

Figure 11 shows facts that explore topics at different geographic scopes: global, national, state/regional. 'Global' refers to data from other countries and broader than just the United States. 'National' includes data that is aggregated or averaged across the entire United States (including automobile fleet averages), while 'state/regional' refers to facts that delineate differences at that resolution (e.g., crude oil production by state, urban areas with the greatest fuel waste from congestion). 
FOTW geographic scope

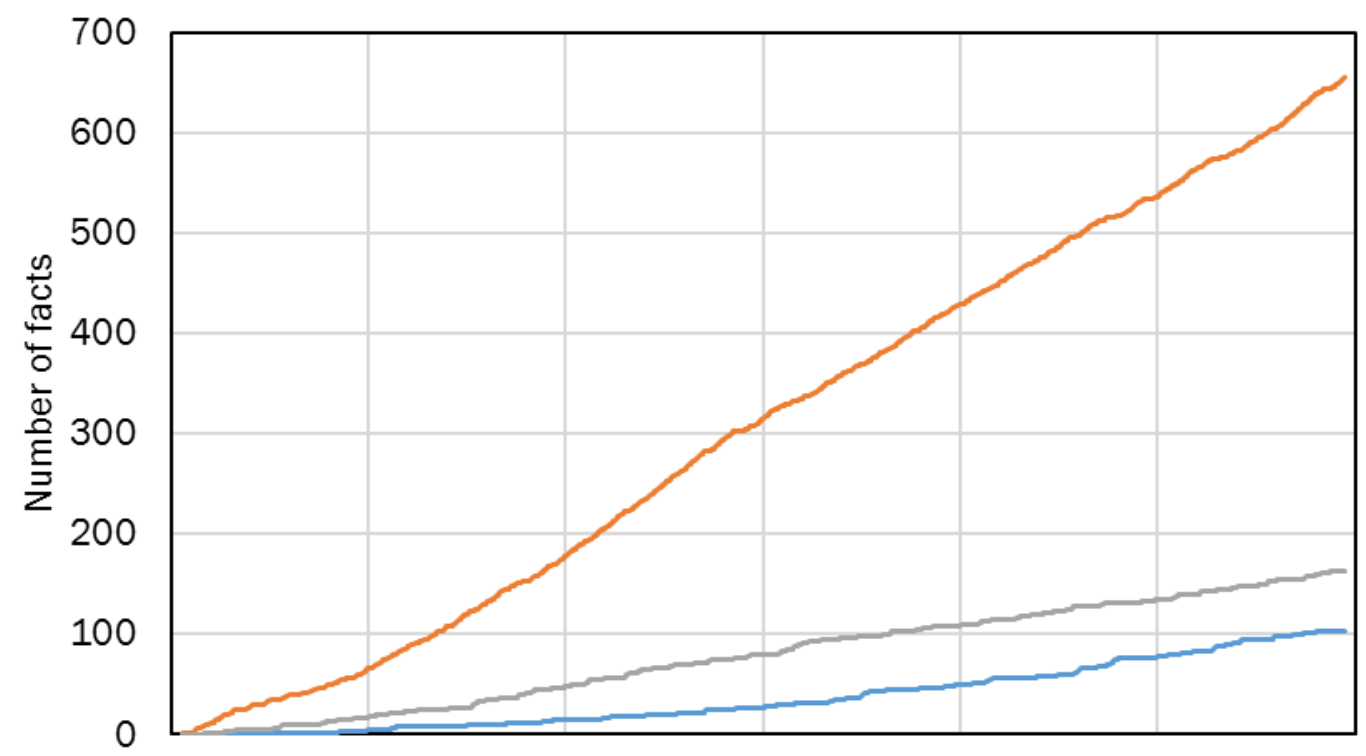

Apr 1996 Dec 1999 Jul 2003 Feb 2007 Oct 2010 May 2014 Dec 2017

- State/Regional - National - Global

Figure 11. Geographic scope of Facts of the Week

Of the facts that fall into these geographic categories, the vast majority of the data (71\%) are aggregated at the national level. About $18 \%$ of the data are at the global/international level, while $11 \%$ are at the local/regional level. These fractions have not seen much variation since the Fact of the Week was first published.

Figure 12 shows the cumulative fraction of facts published through FotW \#1000 with different temporal and geographic scopes, reiterating the prominence of facts showing historical trends and national-scale data.

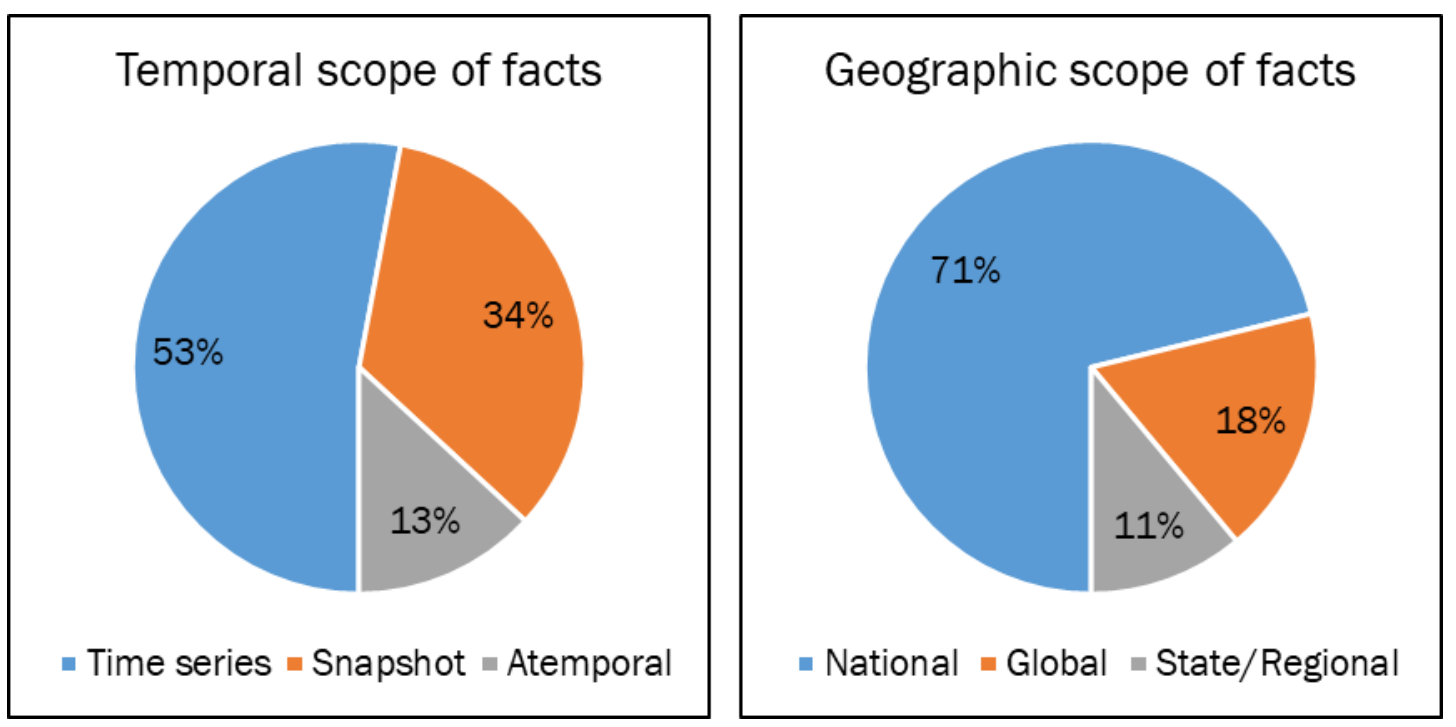

Figure 12. Temporal and geographic scopes of first 1000 Facts of the Week 


\section{Miscellenaeous Trends in the Fact of the Week}

In addition to the detailed examination of the topics of the Fact of the Week, some additional contextual information can be derived from looking at the gaps between facts and by looking at their titles.

Figure 13 shows the gap between consecutive facts on the same topic. The x-axis represents a Fact of the Week number, while the $y$-axis shows how long until the fact was next repeated. The grouping of points below 100 shows the tendency to repeat facts as data is updated, typically on a 1-2-year timeframe, while the outlier points in the upper left show facts that have been repeated less regularly.

Gap between repeated topics

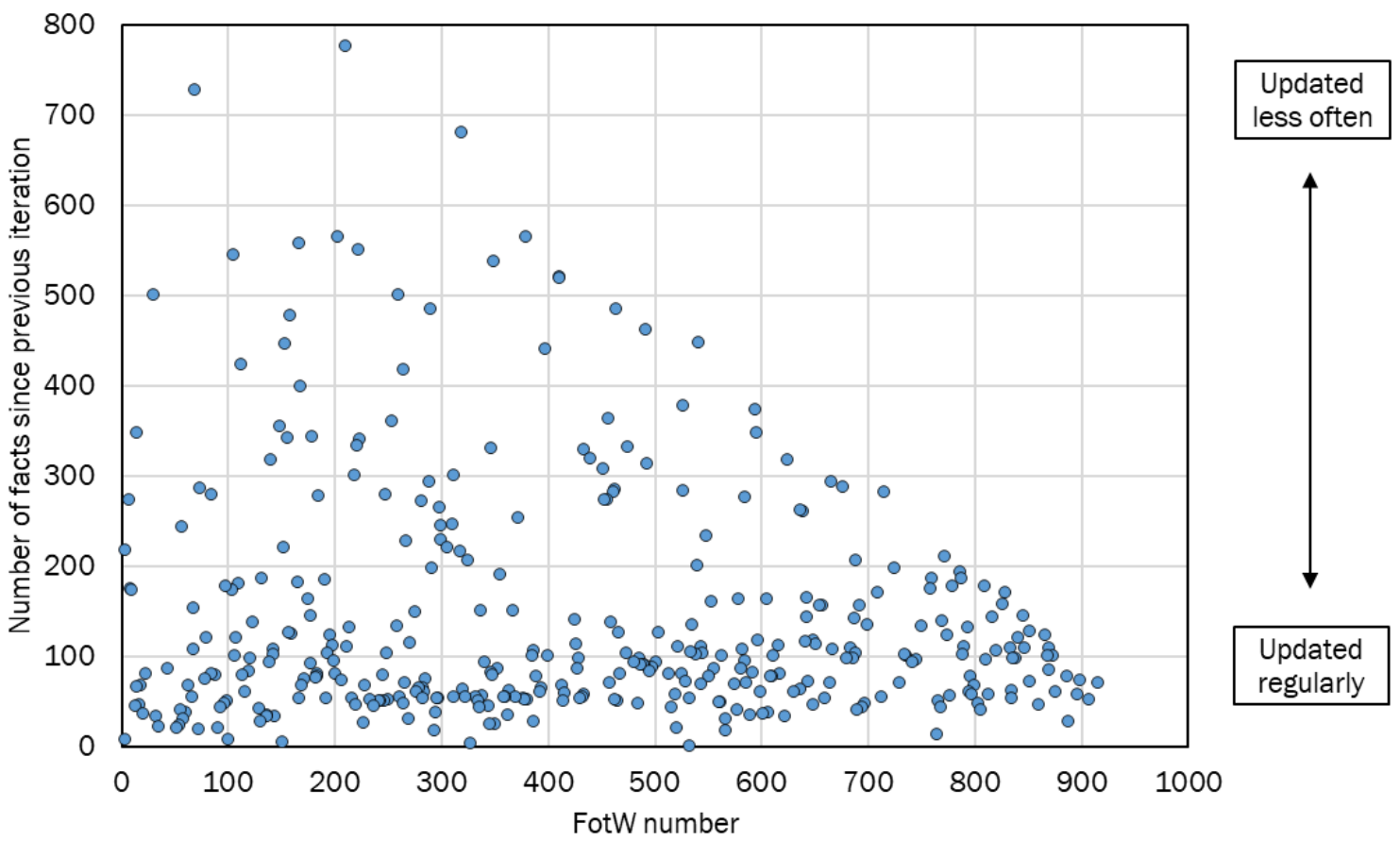

Figure 13. Gap between repeated facts on the same topic

Figure 14 shows the gap (in days) between consecutive Facts of the Week. As noted in Section 1, the Fact of the Week has been published regularly since being hosted on the EERE website $2003 .^{2}$ Before this, the Fact of the Week was generally published weekly, but with less consistency.

\footnotetext{
${ }^{2}$ From 2003 to 2017 there were five breaks of more than one week between publications. In 2006, the Fact of the Week was not posted online due to system upgrades; in 2007, the Fact of the Week was not published over winter holidays; in 2013, the Fact of the Week was not published due to the federal government shutdown; and in 2014, the Fact of the Week was twice delayed due to technical website issues.
} 
Time gap between publication

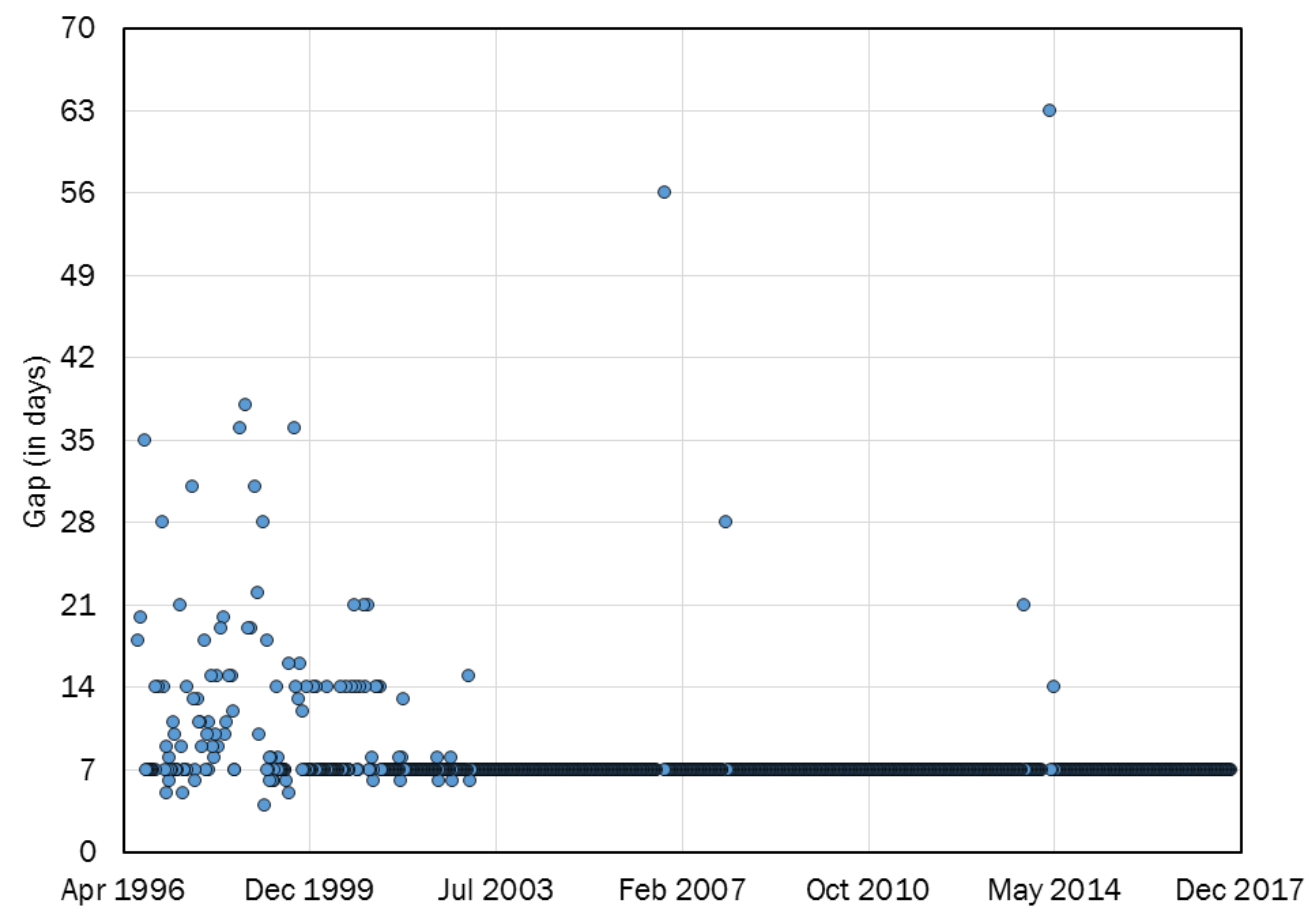

Figure 14. Gap (in days) between publication of consecutive Facts of the Week

The number of words in the title has grown since around 2012. Figure 15 shows the number of words in each title. The moving average trendline shows an upward trend since around FotW \#700, growing from an average of around 7-8 words to over 10 words. The general growth of the title length shows a tendency to be more descriptive in titles, and is indicative of a greater nuance in the facts. ${ }^{3}$

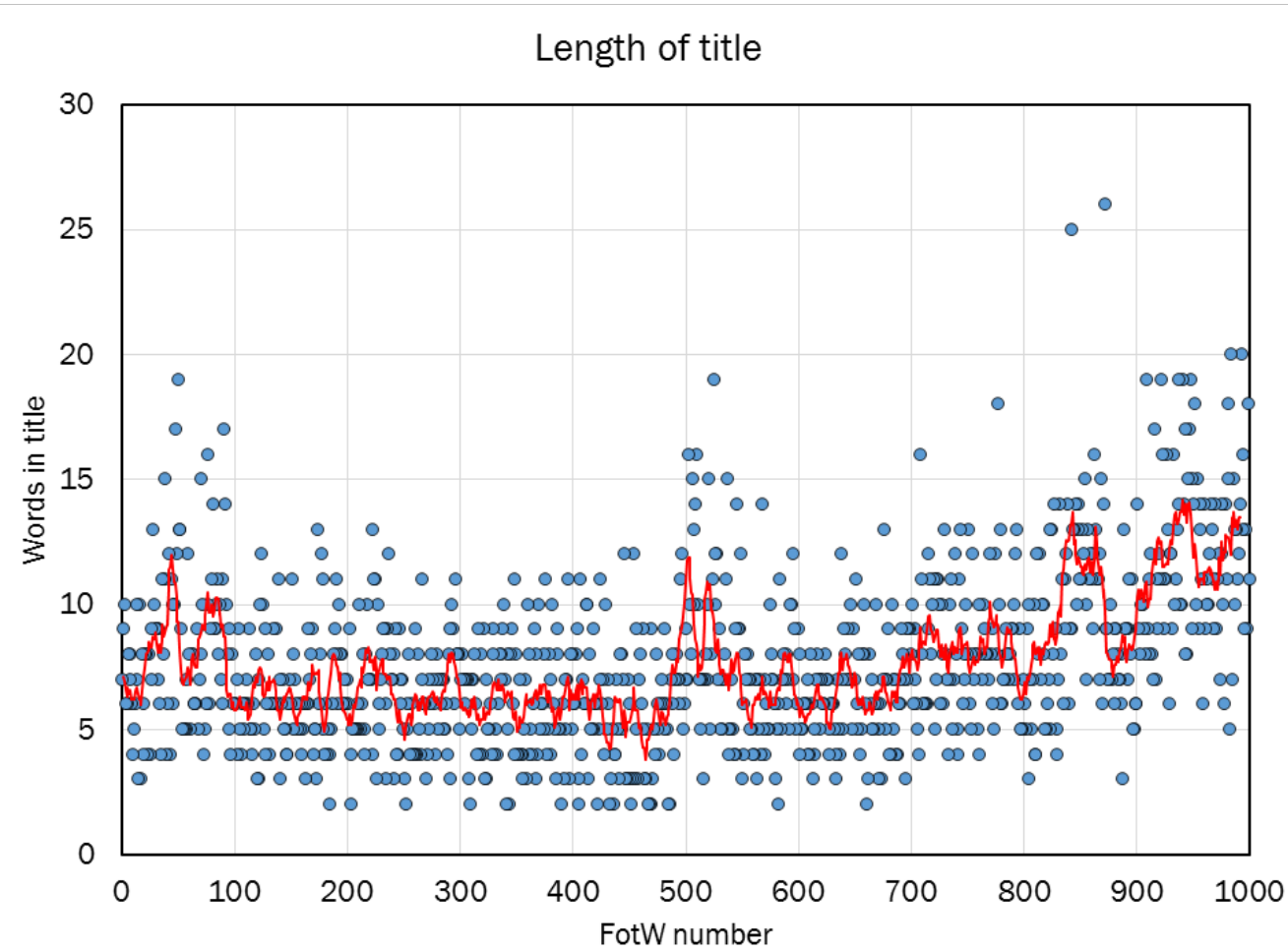

Figure 15. Number of words in the title of each Fact of the Week

${ }^{3}$ Prior to November 1999 (FotW \#105), the Fact of the Week did not always include descriptive text with the figures. 
While less quantitative, a word cloud can also be used to see the most repeated topics in the Fact of the Week. Figure 16 is a word cloud generated using the 250 most common words in the titles of the Fact of the Week, using the online tool available at https://www.jasondavies.com/wordcloud/ (Davies, 2017). Certain words are particularly clear in this representation: "vehicle(s)", "fuel”, "gasoline”, "light”, "production”, “transportation”, “petroleum”, “consumption”, “sales”, “oil”, and “economy” are all among the most frequently used words.

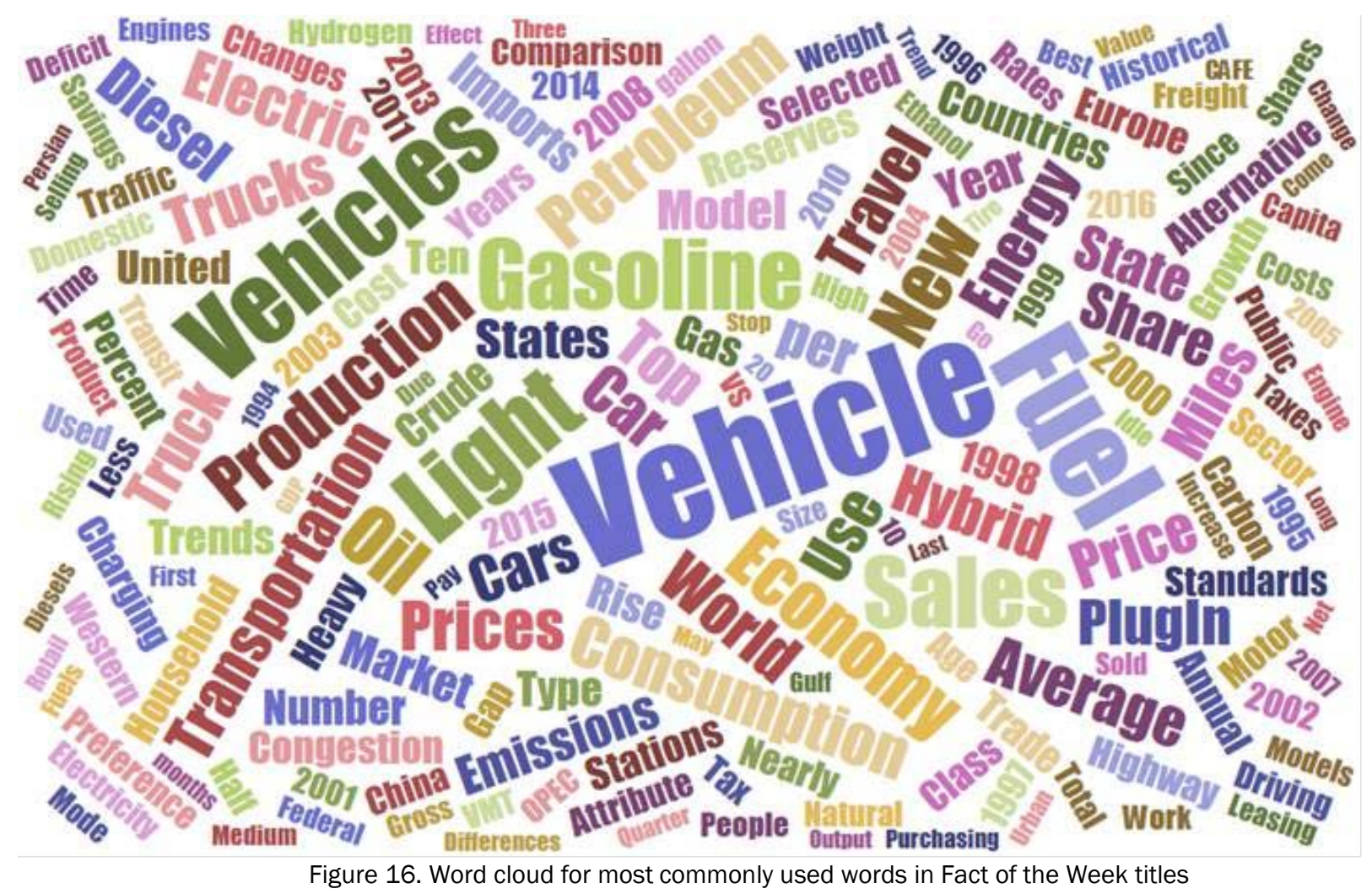




\section{Appendix A: Description of Specific Fact of the Week Topics}

This section explores five specific topics presented as Facts of the Week, giving summaries of the data therein and underlying context. These are five of the most-repeated and most-referenced Facts of the Week, showing their relationship to work done by the Department of Energy.

\section{Comparison of petroleum production and transportation petroleum consumption - FotW \#1000}

Figure 17 displays what is colloquially known as the transportation petroleum gap (DOE, 2017c). Prior to 1988, domestic production of petroleum was sufficient to cover all use for transportation in the United States. However, after this the demand for petroleum in the transportation sector outstripped the production in the United States, and by 1998 the petroleum demand from the on-road sector alone was larger than production. More recently, the growth in transportation demand for petroleum has stopped or slowed, and domestic production is at an all-time high level (EIA, 2017b). With improved efficiency and the recession of the late 2000s demand has reduced, and the shale boom of the last decade has increased production. By 2015, domestic petroleum production exceeded usage in the transportation sector once again. This graphic includes both historical data and projections from the U.S. Energy Information Administration's (EIA) Annual Energy Outlook (AEO) 2017 (EIA, 2017a). This graphic was first published in 1999 as FotW \#73, has been published a total of 10 times, and was revisited on October 23, 2017 to be the milestone FotW \#1000.

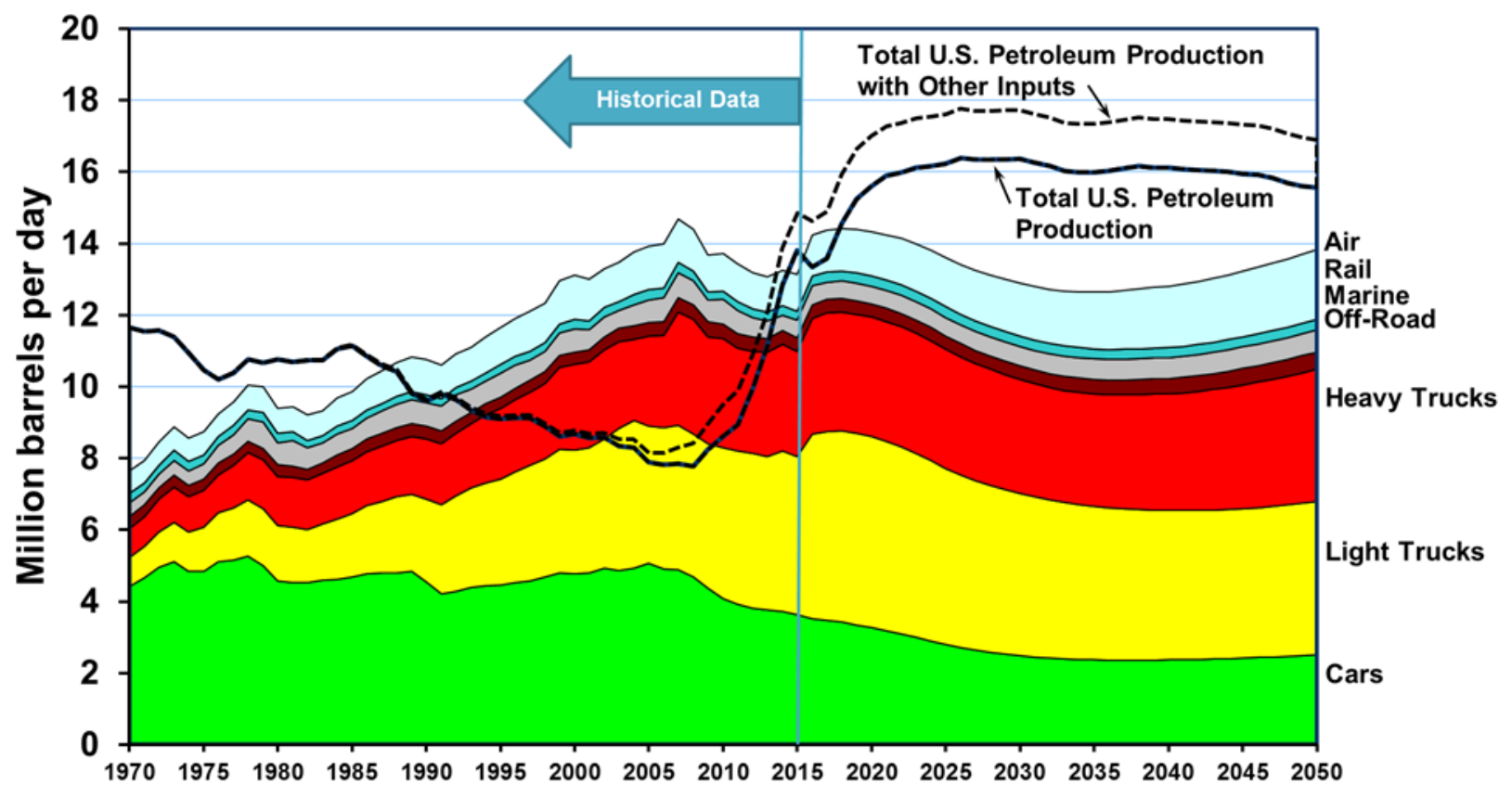

Figure 17. U.S. petroleum production and consumption, FotW \#1000 (DOE, 2017c) 


\section{Historical average gasoline price - FotW \#985}

Figure 18 shows U.S. average gasoline prices in both nominal dollars (which was the purchase price at the time) shown in blue, and inflation-adjusted dollars shown in green (DOE, 2017a). Through most of the $20^{\text {th }}$ century, the inflation-adjusted price of gasoline decreased, with the major exception of the oil price shocks of the 1970s and the 1980s. Since 2000, the gasoline price has been less steady, doubling in one six-year span, and twice dropping by over $25 \%$ in a single year. This particular topic is the most visited Fact of the Week, and is revisited annually with the latest data and a new updated inflation adjustment factor. This graphic has been repeated 10 times from 1997 to July 10, 2017 (FotW \#985).

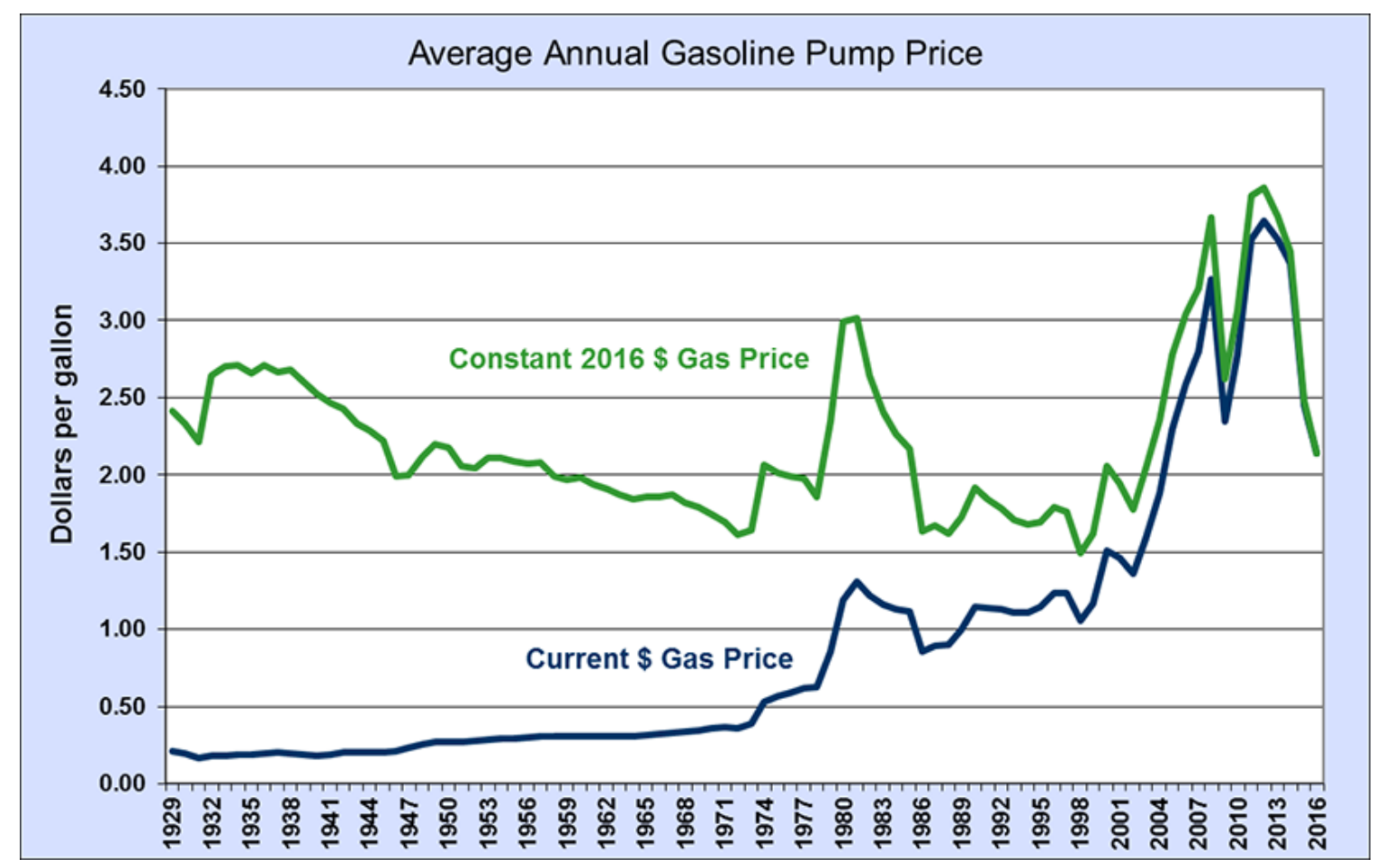

Figure 18. Annual gasoline pump price, FotW \#985 (DOE, 2017a) 
Trends of vehicle fuel economy, vehicle weight, and performance - FotW \#969

Figure 19 shows a comparison of vehicle fuel economy, weight, and performance over time (DOE, 2017b), referencing data published in the EPA Trends Report (EPA, 2016). From the late 1980s through the early 2000s, fuel economy dropped as vehicle weight and horsepower increased. Since 2004, new vehicle fuel economy has increased over 30\%. In spite of the increase in fuel economy, vehicle performance has improved, as the average acceleration rate (0-60 mph time) has nearly doubled since 1980 . This fact has been explored seven times since 2000, and most recently published as FotW \#969 on March 20, 2017.

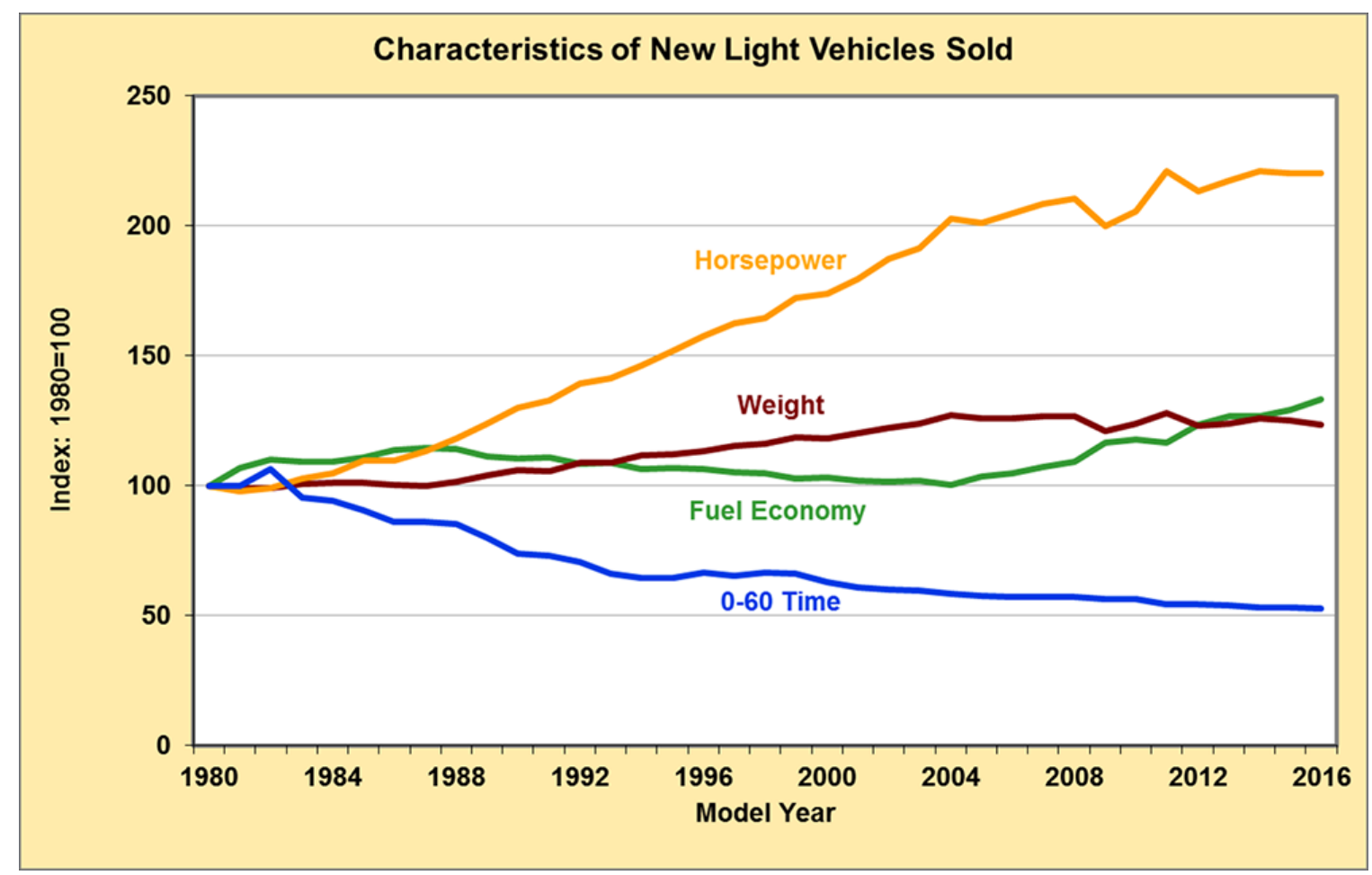

Figure 19. Characteristics of new light vehicles, FotW \#969 (DOE, 2017b) 


\section{Energy used by different modes of transportation - FotW \#953}

On-road transportation uses the majority of energy in the transportation sector in the United States. Figure 20 shows this for six different modes of transportation, and further delineates by the fuel (DOE, 2016b). Onroad vehicles are powered almost exclusively by petroleum-based liquid fuels; gasoline (including ethanol) is prominent for light-duty vehicles, while medium- and heavy-duty vehicles are mostly fueled by diesel. For airborne travel, jet fuel (green) is the most prominent fuel. Waterborne travel uses a mix of gasoline, diesel, and residual fuel. Rail in the United States is largely powered by diesel, though electricity is used for a small portion. Pipelines are used to ship energy commodities such as natural gas and petroleum products; for this mode, natural gas consumption includes operation of compressors and line loss (EIA, 2017b). This graphic was first published in 2001 as FotW \#158 and has been published a total of six times. The most recent publication was November 28, 2016 as FotW \#953.

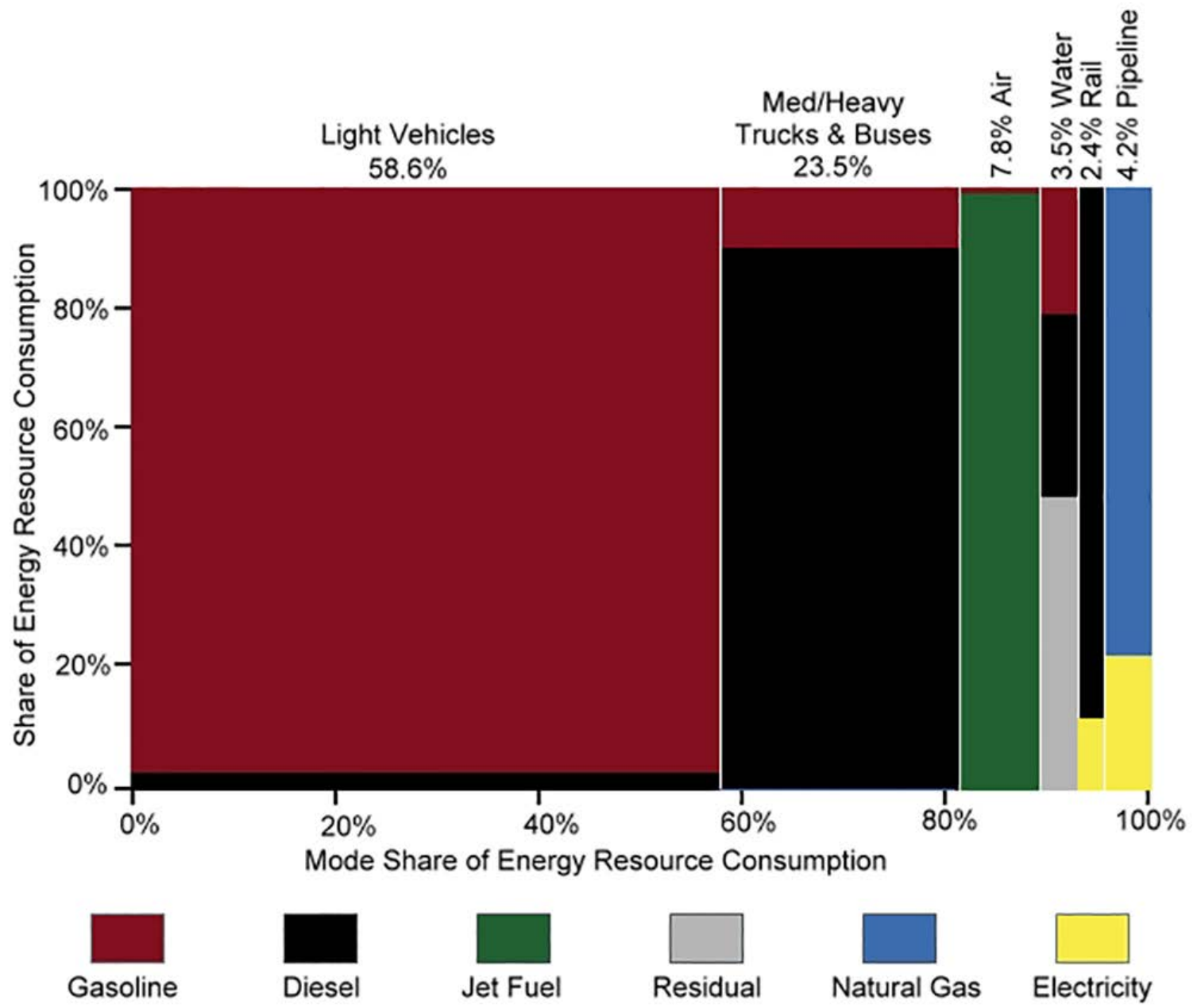

Figure 20. Transportation energy use by mode and fuel type, FotW \#953 (DOE, 2016b) 
Importance to consumers of fuel economy when purchasing a vehicle - FotW \#942

A series of long-standing surveys by J.D. Power and Opinion Research Corportation has asked consumers for their views on different vehicle attributes, including dependability, price, and fuel economy (Singer, 2015). People's opinion on the most important attribute is strongly correlated with the price of fuel, as shown in Figure 21 (DOE, 2016a). When gasoline prices are high, fuel economy is more important, and when gasoline prices are low, dependability and safety hold more prominence. This topic has been the most-often repeated Fact of the Week, at 15 total occurances, starting in February 1997 when the survey was restarted (Kubik, 2006), and was last published with survey data from 2016 on September 12, 2016.

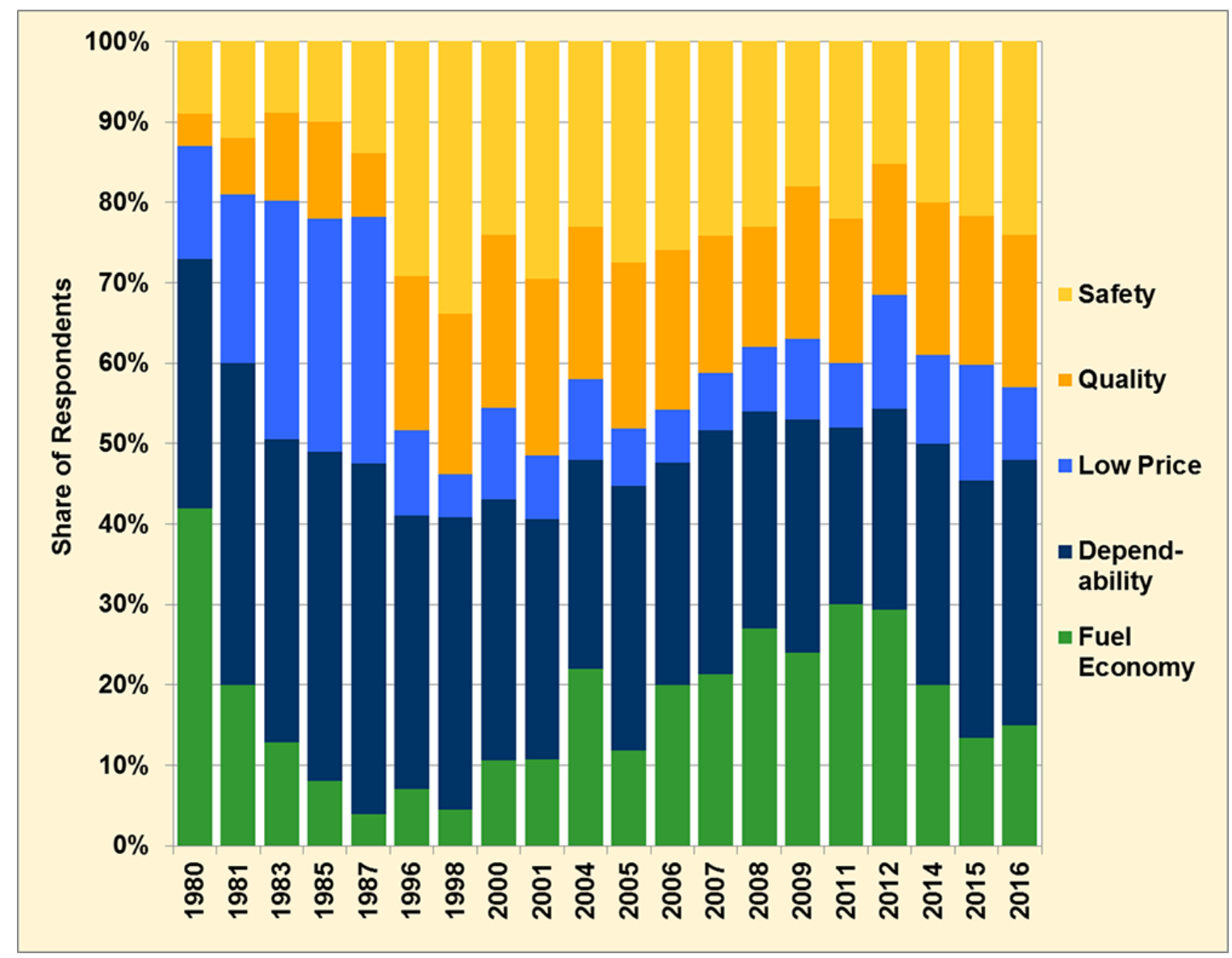

Figure 21. Survey responses for most important vehicle attribute, FotW \#942 (DOE, 2016a) 


\section{Appendix B: Complete List of Facts of the Week}

Table 2 shows a list of every Transportation Analysis Fact of the Week published on the DOE website since 1996.

Table 2. List of Every Transportation Analysis Fact of the Week

\begin{tabular}{|c|c|c|c|}
\hline Number & Fact Title & Number & Fact Title \\
\hline 1 & Increase in Annual Light Vehicle Sales 1980-1995 & 2 & Change in Market Share for 1996 Compared to 1995 \\
\hline 3 & $\begin{array}{c}\text { Changes in Fuel-Cycle Energy Use and Emissions by } \\
\text { Alternative Fuel }\end{array}$ & 4 & Fuel Economy Declines at Higher Speeds \\
\hline 5 & Consumption of Petroleum by End-Use Sector & 6 & $\begin{array}{c}\text { Energy Intensity of Passenger Modes, } 1974 \text { and } \\
1994\end{array}$ \\
\hline 7 & Fines and Taxes Returned to U.S. Treasury & 8 & Means of Transportation to Work, 1980 and 1990 \\
\hline 9 & Percent of Vehicles in Multi-Vehicle Households & 10 & Characteristics of Light Trucks \\
\hline 11 & Total Fuel Cycle Analysis II & 12 & The Value of $2 X$ Fuel Economy \\
\hline 13 & $\begin{array}{l}\text { World Oil Reserves, Production, and Consumption, } \\
1995\end{array}$ & 14 & $\begin{array}{l}\text { Light Truck Share of Light Vehicle Sales } 1970 \text { to } \\
1995\end{array}$ \\
\hline 15 & Imported Oil Use & 16 & $\begin{array}{l}\text { Transportation Oil Use as a Percent of U.S. Oil } \\
\text { Production }\end{array}$ \\
\hline 17 & U.S. Trade Deficit & 18 & Gasoline and Oil Prices in Constant 1995 Dollars \\
\hline 19 & Oil Use in the United States & 20 & Trends in Attribute Preference \\
\hline 21 & The Fuel Savings Benefits of Increasing Fuel Economy & 22 & $\begin{array}{c}\text { Most Valuable Vehicle Safety Attribute for Next } \\
\text { Purchase }\end{array}$ \\
\hline 23 & VMT Annual Growth Rates & 24 & $\begin{array}{l}\text { Total Output of Refined Petroleum Products, } 1994 \\
\qquad(\mathrm{mbpd})\end{array}$ \\
\hline 25 & 1995 U.S. Propane Supplied & 26 & Carbon Dioxide Emissions by Sector in 1995 \\
\hline 27 & $\begin{array}{l}\text { Gasoline and Diesel Fuel Prices for Selected } \\
\text { Countries, } 1996\end{array}$ & 28 & $\begin{array}{l}\text { Oil Use by Heavy Trucks Exceeds Combined Oil Use by } \\
\text { Buildings and Utilities }\end{array}$ \\
\hline 29 & $\begin{array}{l}\text { Average Annual Vehicle Miles per Household by Trip } \\
\text { Purpose (1990) }\end{array}$ & 30 & $\begin{array}{c}\text { Towing Capacity for Selected } 1996 \text { Model Cars and } \\
\text { Trucks }\end{array}$ \\
\hline 31 & $\begin{array}{l}\text { Top Purchase Factors for Medium and Heavy Vehicle } \\
\text { Owners }\end{array}$ & 32 & Average Price of a New Car, 1970 to 1996 \\
\hline 33 & $\begin{array}{l}\text { Estimated Number of Alternative-Fueled Vehicles in } \\
\qquad 1995\end{array}$ & 34 & Total National Emissions by Sector, 1994 \\
\hline 35 & 1996 Worldwide Vehicle Production & 36 & $\begin{array}{c}\text { Heavy Truck Buyers Willingness to Pay Premium for } \\
\text { Alternative Fuel Vehicles }\end{array}$ \\
\hline 37 & $\begin{array}{l}\text { Payback Period Expected for Alternative Fuel Heavy } \\
\text { Vehicles }\end{array}$ & 38 & $\begin{array}{l}\text { Estimated Number of Electric Vehicles that } \\
\text { Automakers Must Sell in New York to Avoid Fines }\end{array}$ \\
\hline 39 & $\begin{array}{c}\text { Top Reasons Why Consumers Would Not Buy a Diesel } \\
\text { Powered Vehicle }\end{array}$ & 40 & Motor Vehicle Death Rates \\
\hline 41 & $\begin{array}{c}\text { Personal Consumption Expenditures for User- } \\
\text { Operated Transportation }\end{array}$ & 42 & $\begin{array}{c}\text { People } 65 \text { and Over Account for Nearly One-Quarter } \\
\text { of Domestic Automaker's Sales }\end{array}$ \\
\hline 43 & Passenger Car Operating Cost & 44 & $\begin{array}{c}\text { Change in Number of Residential Vehicles by Type, } \\
1988 \text { to } 1994\end{array}$ \\
\hline 45 & $\begin{array}{l}\text { Light Trucks Share of Residential Vehicle Fleet by } \\
\text { Region, } 1994 .\end{array}$ & 46 & Public Perception of U.S. Oil Imports \\
\hline 47 & $\begin{array}{c}\text { Type of Vehicle Previously Owned Before Buying a } \\
\text { Ford Explorer }\end{array}$ & 48 & $\begin{array}{c}\text { Greenhouse Gas Emissions for Ethanol Based Fuels } \\
\text { Relative to Reformulated Gasoline (RFG) on a Fuel } \\
\text { Cycle Basis. }\end{array}$ \\
\hline 49 & $\begin{array}{l}\text { Percent of Americans that Worry a Great Deal About } \\
\text { Selected Environmental Problems }\end{array}$ & 50 & $\begin{array}{c}\text { Light Trucks Enjoy a Substantial Regulatory } \\
\text { Advantage Over Cars - A Comparison of Regulations } \\
\text { for Cars and Light Trucks }\end{array}$ \\
\hline 51 & $\begin{array}{l}\text { Sales of Selected Vehicle Models in the U.S. } 1997 \\
\text { Calendar Year (11 months) }\end{array}$ & 52 & $\begin{array}{c}\text { Car v. Light Truck Sales in the U.S. } 1997 \text { Calendar } \\
\text { Year (11 months) }\end{array}$ \\
\hline 53 & $\begin{array}{l}\text { Estimate of Transportation Energy Use and Carbon } \\
\text { Emissions, } 1997\end{array}$ & 54 & U.S. Light Vehicle Sales, 1997 \\
\hline 55 & U.S. Medium/Heavy Truck Sales, 1997 & 56 & Trends in Vehicle Attribute Preference \\
\hline 57 & 1997 World Wide Vehicle Production & 58 & $\begin{array}{l}\text { World Oil Reserves, Production, and Consumption, } \\
1997\end{array}$ \\
\hline 59 & $\begin{array}{c}\text { Vehicle Efficiency and Fuel Substitution Show Greater } \\
\text { Promise than VMT Reduction Efforts }\end{array}$ & 60 & $\begin{array}{c}\text { World Natural Gas Reserves, Production, and } \\
\text { Consumption, } 1996\end{array}$ \\
\hline 61 & Growth in Motor Vehicles 1940-1996 & 62 & Car and Light-truck Models on the U.S. Market \\
\hline 63 & U.S. Trade Deficit (1997 and 1st Quarter, 1998) & 64 & Global Vehicle Sales by Region 1997 \\
\hline 65 & U.S. Truck Sales by Class 1993-1997 & 66 & Average Expenditure per New Car 1988-1997 \\
\hline 67 & BTU per Passenger Mile for U.S. Transit in 1995 & 68 & What Fuel Will Replace Gasoline? \\
\hline 69 & U.S. Electric Vehicle Sales/Leases Since Late 1996 & 70 & $\begin{array}{c}\text { Estimate of Particulate Matter from Selected } \\
\text { Sources, } 1990\end{array}$ \\
\hline
\end{tabular}




\begin{tabular}{|c|c|c|c|}
\hline Number & Fact Title & Number & Fact Title \\
\hline 71 & $\begin{array}{l}\text { Employees of Motor Vehicles and Related Industries } \\
\text { as a Percent of Total U.S. Employment, } 1994\end{array}$ & 72 & $\begin{array}{c}\text { Car-Truck Sales Split in the U.S. Market Through } \\
\text { October } 1998\end{array}$ \\
\hline 73 & Transportation Oil Gap 1970-1997 & 74 & Women's Share of Retail Sales \\
\hline 75 & World Oil Consumption, 1950 \& 1996 & 76 & $\begin{array}{c}\text { The Transportation Sector is Projected to Increase its } \\
\text { Share of U.S. Oil Use and Carbon Emissions }\end{array}$ \\
\hline 77 & $\begin{array}{l}\text { Vehicle Production in Japan and North America, } 1997 \\
\qquad \& 1998\end{array}$ & 78 & 1998 U.S. Sales of Light Vehicles \\
\hline 79 & $\begin{array}{c}1998 \text { Worldwide Light Vehicle Sales for Top Five } \\
\text { Manufacturers }\end{array}$ & 80 & $\begin{array}{l}\text { Light Truck Market Share of Light Vehicle Market } \\
1908 \text { to } 1998\end{array}$ \\
\hline 81 & $\begin{array}{l}\text { Acceleration Time for the Top Selling } 1998 \text { Models } \\
\text { (seconds to accelerate from } 0-60 \mathrm{mph} \text { ) }\end{array}$ & 82 & $\begin{array}{c}\text { Carbon Emission Coefficients at Full Combustion } \\
\text { (MMTC per Quad) }\end{array}$ \\
\hline 83 & $\begin{array}{c}\text { Single Most Important Reason Why Consumers } \\
\text { Bought Type of Vehicle }\end{array}$ & 84 & U. S. Sport Utility Vehicle Sales 1997 \& 1998 \\
\hline 85 & $\begin{array}{l}\text { Gasoline and Oil Prices in Constant } 1995 \text { Dollars } \\
1918 \text { to } 1999\end{array}$ & 86 & U.S. Sport Utility Vehicle Sales 1976 to 1998 \\
\hline 87 & $\begin{array}{l}\text { Average Annual Miles per Vehicle by Vehicle Type and } \\
\text { Age }\end{array}$ & 88 & $\begin{array}{l}\text { World Oil Reserves, Production, and Consumption, } \\
1998\end{array}$ \\
\hline 89 & $\begin{array}{l}\text { Light Vehicle Market Shares by Type for 1978, 1988, } \\
\text { and } 1998\end{array}$ & 90 & Congested Travel in Major Metropolitan Areas \\
\hline 91 & $\begin{array}{l}\text { Percent of Car Sales v. Truck Sales in U.S. for Leading } \\
\text { Automakers (First Four Months of 1999) }\end{array}$ & 92 & $\begin{array}{c}\text { Percent of Vehicle Buyers Who Are Considering an } \\
\text { SUV for Their Next Vehicle Purchase }\end{array}$ \\
\hline 93 & $\begin{array}{c}\text { Diesel Share of Passenger Car Sales in Western } \\
\text { Europe, 1988-1999 }\end{array}$ & 94 & $\begin{array}{l}\text { Being Productive Does Not Translate to Being } \\
\text { Profitable }\end{array}$ \\
\hline 95 & Survey Finds Interest in Gasoline-HEVs & 96 & VMT by Light Truck Type for Selected Purposes, 1995 \\
\hline 97 & Trends in Attribute Preference & 98 & $\begin{array}{c}\text { World Natural Gas Reserves, Production, and } \\
\text { Consumption, } 1997\end{array}$ \\
\hline 99 & Most Important Transportation Problem in 2020 & 100 & U.S. Light Vehicle Sales Shares, 1976-1999 \\
\hline 101 & Consumer Preferences for Fuel Efficient Vehicles & 102 & World Fossil Fuel Potential \\
\hline 103 & Energy Intensity of Modes of Travel 1970-1997 & 104 & $\begin{array}{l}\text { Growth Rate of Light-Duty Vehicle Miles of Travel, } \\
\text { 1969-1997 }\end{array}$ \\
\hline 105 & Number of New Vehicle Dealerships & 106 & Number of Refueling Stations \\
\hline 107 & Gasoline Prices and Light Vehicle Sales & 108 & U.S. Light Vehicle Sales Shares, 1976-1999 \\
\hline 109 & OPEC and OPEC+ Market Shares & 110 & Annual Costs of Traffic Congestion, 1997 \\
\hline 111 & Dealer Profits by Market Segment, October 1999 & 112 & Light Vehicle Miles of Travel, 1969-1997 \\
\hline 113 & $\begin{array}{l}\text { Fuel Conservation Equipment on Medium and Heavy } \\
\text { Trucks, 1992-1997 }\end{array}$ & 114 & OPEC and OPEC+ Resource Shares \\
\hline 115 & NOx Emissions from Highway Vehicles & 116 & Light Vehicle Leases, 1984-1995 \\
\hline 117 & Top Ten Fossil Energy Producing Nations & 118 & Light Vehicle Scrappage Rates, 1970-1999 \\
\hline 119 & Retail Gasoline and Diesel Prices Rise in 1999 & 120 & Gasoline Taxes, 1975-1998 \\
\hline 121 & Automobile Affordability, 1979-1999 & 122 & Potential Fuel Savings of Doubling Fuel Economy \\
\hline 123 & $\begin{array}{l}\text { U.S. Gasoline and Oil Prices, January } 1998 \text { - March } \\
\qquad 2000\end{array}$ & 124 & $\begin{array}{c}\text { Average Gasoline and Diesel Fuel Retail Prices, Jan. } \\
1999 \text { - April } 2000\end{array}$ \\
\hline 125 & $\begin{array}{c}\text { Reserve to Production Ratios for Top Ten Oil } \\
\text { Producing Nations }\end{array}$ & 126 & Transportation Carbon Emissions by Mode \\
\hline 127 & State Automobile Registration Fees & 128 & $\begin{array}{l}\text { PNGV Concept Vehicles Presented to the Public in } \\
\qquad 2000\end{array}$ \\
\hline 129 & Cost of Automobile Ownership and Operation & 130 & U.S. Trade Deficit, First Quarter 1999 and 2000 \\
\hline 131 & State Fuel Taxes, 1998 & 132 & Per Capita Lane Miles by State \\
\hline 133 & Accident Fatalities by Vehicle Type, 1998 & 134 & Accident Fatalities by Crash Type, 1998 \\
\hline 135 & $\begin{array}{c}\text { Accidents with Driver Alcohol Involvement by Vehicle } \\
\text { Type, } 1998\end{array}$ & 136 & Diesel Car Sales, Western Europe, 1999 \\
\hline 137 & $\begin{array}{l}\text { Components of Gasoline Price, June } 2000 \text { vs. June } \\
1999\end{array}$ & 138 & Potential Fuel Saved by Increased Efficiency \\
\hline 139 & $\begin{array}{c}\text { International Vehicle Ownership in } 1998 \text { Compared } \\
\text { to the U.S. from 1900-1998 }\end{array}$ & 140 & Gasoline Price Expectations \\
\hline 141 & New Vehicle Fuel Cost per Mile, 1978-1999 & 142 & Public Knowledge of Hybrid Electric Vehicles \\
\hline 143 & Public Knowledge of Hybrid Electric Vehicle Models & 144 & Trends in Vehicle Attribute Preference \\
\hline 145 & Actions to Reduce Gasoline Expenditures & 146 & World Vehicle Population, 1960-2020 \\
\hline 147 & World Vehicle Sales, 1960-2020 & 148 & SUV Sales Pass Pickups in 2000 \\
\hline 149 & Historic U.S. New Light Vehicle Fuel Economy & 150 & Most Important Transportation Problem in 2020 \\
\hline 151 & $\begin{array}{l}\text { New Car and Light Truck Fuel Economy, 1975, 1988, } \\
\text { and } 2000\end{array}$ & 152 & $\begin{array}{l}\text { Truck Fuel Economy by Vehicle Weight Class, 1977- } \\
\qquad 1997\end{array}$ \\
\hline 153 & U.S. Light Vehicle Sales, 2000 & 154 & U.S. Light Vehicle Sales by Manufacturer, 1999-2000 \\
\hline 155 & U.S. Light Vehicle Energy Use Projections & 156 & U.S. Automobile Fuel Economy, 1970-2000 \\
\hline 157 & U.S. Trade Deficit, 1999 \& 2000 & 158 & U.S. Highway Energy Use, 1978-1998 \\
\hline 159 & U.S. Vehicle Travel and Gasoline Price & 160 & U.S. Petroleum Consumption, 1970-2020 \\
\hline 161 & Potential Fuel Savings in 2010 & 162 & Public Support for Fuel Conservation Policies \\
\hline
\end{tabular}




\begin{tabular}{|c|c|c|c|}
\hline Number & Fact Title & Number & Fact Title \\
\hline 163 & Highway Indicators, 1979-1999 & 164 & SUVs Continue to Gain Market Share \\
\hline 165 & $\begin{array}{l}\text { Gross Domestic Product and Vehicle Miles of Travel, } \\
1960-1999\end{array}$ & 166 & Consumers Pay More for Gas Guzzling Automobiles \\
\hline 167 & $\begin{array}{l}\text { World Oil Reserves, Production, and Consumption, } \\
2000\end{array}$ & 168 & Light Truck Sales Influence Average Age of Trucks \\
\hline 169 & Diesel Car Sales in Western Europe, 1999 and 2000 & 170 & Fuel Economy Saves $\$ \$ \$$ \\
\hline 171 & Passenger Car Operating Costs, 1990-2000 & 172 & The Cost Components of Gasoline \\
\hline 173 & Urban Travel Congestion & 174 & $\begin{array}{l}\text { Potential Benefits of Alternative Future On-Road MPG } \\
\text { Gains in Light Vehicles in } 2010\end{array}$ \\
\hline 175 & Electricity Chosen over Ethanol and Hydrogen & 176 & Public Transportation Takes Twice as Long as Driving \\
\hline 177 & $\begin{array}{l}\text { The Large Growth in Vehicle Leasing May Have Come } \\
\text { to an End }\end{array}$ & 178 & $\begin{array}{c}\text { Trends in New Vehicle Attribute Preference over the } \\
\text { Past } 20 \text { Years }\end{array}$ \\
\hline 179 & The Costs of Oil Dependence & 180 & Comparison of Commute Times \\
\hline 181 & Carpooling Is Down Again in 2000 & 182 & Households by Vehicle Ownership \\
\hline 183 & Means of Transportation to Work & 184 & State Average Gasoline Prices \\
\hline 185 & Household Expenditures & 186 & Per Capita Vehicles Rising Steadily \\
\hline 187 & Highway Crashes and Fatalities in 2000 & 188 & Transit Share of Travel for Selected Worldwide Cities \\
\hline 189 & $\begin{array}{c}\text { Time Spent on Travel Is Fairly Constant across } \\
\text { Countries }\end{array}$ & 190 & Growth in Passenger Car Ownership around the World \\
\hline 191 & $\begin{array}{l}\text { U.S. Oil Consumption Nearly } 20 \text { Million Barrels per } \\
\text { Day in } 2000\end{array}$ & 192 & Where Does Our Oil Come From? \\
\hline 193 & $\begin{array}{c}\text { Oil Production: OPEC, the Persian Gulf, and the } \\
\text { United States }\end{array}$ & 194 & $\begin{array}{l}\text { Production and Imports/Exports for Top } 10 \text { Oil- } \\
\text { Producing Countries }\end{array}$ \\
\hline 195 & $\begin{array}{l}\text { Public Strongly Supports Requirements for More Fuel- } \\
\text { Efficient Cars }\end{array}$ & 196 & $\begin{array}{l}\text { Highway Vehicle Emissions-1970 to } 1999 \\
\text { Comparison }\end{array}$ \\
\hline 197 & What are the big trucks hauling? & 198 & $\begin{array}{l}\text { Average Material Consumption for a Domestic } \\
\text { Automobile }\end{array}$ \\
\hline 199 & Best-Selling Cars and Light Trucks, 2001 & 200 & U.S. Light Truck Sales Exceed Car Sales \\
\hline 201 & Top 10 Countries with Oil Reserves & 202 & $\begin{array}{c}\text { Urban Motor Vehicle Travel Growing Faster than Rural } \\
\text { Travel }\end{array}$ \\
\hline 203 & Federal Motor Fuel Taxes & 204 & Hydrogen Facts \\
\hline 205 & Hydrogen Cost and Worldwide Production & 206 & Gasoline Stations on the Decline \\
\hline 207 & U.S. Greenhouse Gas Emissions Indicators & 208 & CAFE Standards Reduce Petroleum Use \\
\hline 209 & Fossil Fuel Production to Consumption, $1950-2000$ & 210 & Crude Oil Prices Since 1870 \\
\hline 211 & $\begin{array}{c}\text { Days of Reserves Stored in the Strategic Petroleum } \\
\text { Reserve (SPR) }\end{array}$ & 212 & Speed Limits: Are They Rising? \\
\hline 213 & Estimates of Vehicle Miles of Travel & 214 & What Is Made from a Barrel of Oil? \\
\hline 215 & Transporting the Oil We Use & 216 & Telecommuting on the Rise \\
\hline 217 & Road Mileage and Travel by Functional Class, 2000 & 218 & $\begin{array}{c}\text { Operating Costs by Type of Vehicle - What's the } \\
\text { Difference? }\end{array}$ \\
\hline 219 & Average Price of a New Car, 1970-2001 & 220 & $\begin{array}{l}\text { World Oil Reserves, Production, and Consumption, } \\
2001\end{array}$ \\
\hline 221 & Transit Rail Energy Intensity Varies By System & 222 & $\begin{array}{l}\text { Speed versus Fuel Economy: Slow down to get more } \\
\text { miles to the gallon }\end{array}$ \\
\hline 223 & Transportation and the GDP & 224 & $\begin{array}{c}\text { Statistics on Class } 1 \text {, Class 2a, and Class 2b Light } \\
\text { Trucks }\end{array}$ \\
\hline 225 & $\begin{array}{c}\text { Diesel Share of Light Trucks-Class 1, Class 2a, \& } \\
\text { Class 2b }\end{array}$ & 226 & Tire Inflation Facts \\
\hline 227 & Vehicle Miles of Travel (VMT) and Age by Vehicle Type & 228 & New Light Vehicle Sales Shares, 1976-2001 \\
\hline 229 & Medium and Heavy Truck Sales & 230 & Hybrid Electric Vehicles in the United States \\
\hline 231 & Transportation's Energy Use per GDP on the Decline & 232 & $\begin{array}{c}\text { World Transportation Energy Consumption per GDP } \\
\text { Dollar by Region }\end{array}$ \\
\hline 233 & $\begin{array}{c}\text { Vehicles per Thousand People: U.S. Compared to } \\
\text { Other Countries }\end{array}$ & 234 & 2003 Model Year Alternative Fuel Vehicles \\
\hline 235 & Full Fuel-Cycle Emissions & 236 & $\begin{array}{c}\text { Business Fleet Vehicles: How Long Are They in } \\
\text { Service? }\end{array}$ \\
\hline 237 & $\begin{array}{c}\text { Diesel Car Sales in Western European Countries- } \\
\text { First Six Months, } 2001 \text { and } 2002\end{array}$ & 238 & $\begin{array}{l}\text { Automobile and Truck Population by Vehicle Age, } \\
\qquad 2001\end{array}$ \\
\hline 239 & Motor Vehicle Trade for Selected Countries, 2001 & 240 & $\begin{array}{l}\text { Vehicle Ownership Rates Increasing in Developing } \\
\text { Nations }\end{array}$ \\
\hline 241 & Biodiesel Lowers Emissions & 242 & Fuel Economy Leaders for 2003 Model Year Cars \\
\hline 243 & $\begin{array}{c}\text { Fuel Economy Leaders for } 2003 \text { Model Year Light } \\
\text { Trucks }\end{array}$ & 244 & Sport Utility Vehicle Spotlight \\
\hline 245 & Hybrids Gain in Recognition & 246 & U.S. Oil Imports - Top 10 Countries of Origin \\
\hline 247 & Components of Diesel Fuel Price, 2002 & 248 & Top Ten Net Petroleum Importing Countries, 2000 \\
\hline 249 & Crude Oil Production in the United States & 250 & Public Knowledge of Hybrid Technology \\
\hline 251 & Hybrid Vehicle Sales & 252 & Driving Irritations \\
\hline
\end{tabular}




\begin{tabular}{|c|c|c|c|}
\hline Number & Fact Title & Number & Fact Title \\
\hline 253 & Vehicle Age by Type of Vehicle & 254 & MSA Transit Commuter Trends, 1990-2000 \\
\hline 255 & Men versus Women: Average Annual Miles per Driver & 256 & Petroleum Product Prices Rise \\
\hline 257 & Vehicle Occupancy by Type of Vehicle & 258 & Vehicle Ownership Trends 1969-2001 \\
\hline 259 & Household Travel by Gender & 260 & Commuting to Work, $1960-2000$ \\
\hline 261 & $\begin{array}{c}\text { U.S. Gasoline and Crude Oil Prices, January 1998- } \\
\text { February } 2003\end{array}$ & 262 & Europeans Favor Renewables Research \\
\hline 263 & $\begin{array}{l}\text { Europeans Consider Energy Use when Purchasing a } \\
\qquad \text { Car }\end{array}$ & 264 & Production of Ethanol and MTBE \\
\hline 265 & State Average Fuel Prices & 266 & $\begin{array}{l}\text { World Oil Reserves, Production, and Consumption, } \\
2002\end{array}$ \\
\hline 267 & $\begin{array}{l}\text { Oil Price Relationship to Economic Growth in the } \\
\text { United States, } 1970-2002\end{array}$ & 268 & New Hybrids Getting Better Fuel Economy \\
\hline 269 & Leasing Rate is Up in 2002 & 270 & U.S. Telecommuting, 1990-2001 \\
\hline 271 & Attitudes about Hybrid SUVs & 272 & Why Buyers Are Not Considering SUV Purchases \\
\hline 273 & Europeans Charging for Traffic Congestion & 274 & Americans Willing to Try Hydrogen-Fueled Vehicles \\
\hline 275 & Safety Ranks as Top Concern for New Fuels & 276 & $\begin{array}{l}\text { Natural Gas Reserves, Production, and Consumption, } \\
2000\end{array}$ \\
\hline 277 & Light Truck Sales by Type, 1976-2002 & 278 & Annual VMT Growth Rates \\
\hline 279 & $\begin{array}{l}\text { Number of Retail Outlets Selling Gasoline, 1993- } \\
\qquad 2002\end{array}$ & 280 & $\begin{array}{l}\text { Fines and Taxes Related to Fuel Economy, 1980- } \\
\qquad 2001\end{array}$ \\
\hline 281 & Historical Light Vehicle Market Share & 282 & Diesel Sales Continue to Climb in Europe \\
\hline 283 & U.S. Trade Deficit, 2001 \& 2002 & 284 & U.S. Vehicle Travel and Gasoline Prices, 2001-2003 \\
\hline 285 & $\begin{array}{c}\text { Vehicles per Thousand People: An International } \\
\text { Comparison }\end{array}$ & 286 & Public Opinion on Oil Dependence \\
\hline 287 & Modes of Transport, May 2003 & 288 & Primary Energy Sources by Sector, 2002 \\
\hline 289 & U.S. Energy Consumption, 2002 & 290 & Top Twenty Congested Cities in the U.S., 2001 \\
\hline 291 & Traffic Congestion, 2001 & 292 & Most Fuel Efficient MY 2004 Cars by Size Class \\
\hline 293 & $\begin{array}{c}\text { Most Fuel Efficient MY } 2004 \text { Light Trucks by Size } \\
\text { Class }\end{array}$ & 294 & Best Selling Cars and Light Trucks, Model Year 2003 \\
\hline 295 & New Light Vehicle Market Shares, 1976-2002 & 296 & $\begin{array}{c}\text { Crude Oil Production: OPEC, the Persian Gulf, and the } \\
\text { United States }\end{array}$ \\
\hline 297 & Imported Crude Oil: Where Does It Come From? & 298 & OPEC and Persian Gulf Share of U.S. Imports \\
\hline 299 & Light Vehicle Leasing is On the Rise Again & 300 & World Vehicle Production by Country/Region \\
\hline 301 & $\begin{array}{l}\text { Number of Household Vehicles Has Grown } \\
\text { Significantly }\end{array}$ & 302 & More People Can Name Hybrid Cars in 2003 \\
\hline 303 & Top Ten Countries with Natural Gas Vehicles & 304 & $\begin{array}{c}\text { Hybrid Vehicle Purchases Earn Federal Tax } \\
\text { Deductions }\end{array}$ \\
\hline 305 & More V-8 Engines in the U.S. & 306 & Vehicle Type Differences on Vehicle Miles Traveled \\
\hline 307 & Business Travel: By Land or by Air? & 308 & Holiday Travel 2001 \\
\hline 309 & Transporting Petroleum & 310 & $\begin{array}{l}\text { Average Material Consumption for a Domestic } \\
\text { Automobile }\end{array}$ \\
\hline 311 & Calendar Year 2003 Best Sellers & 312 & State Average Fuel Prices, 2003 vs. 2004 \\
\hline 313 & $\begin{array}{l}\text { U.S. International Trade by Mode of Transportation, } \\
\qquad 2002\end{array}$ & 314 & $\begin{array}{l}\text { U.S. Trade in Transportation-Related Commodities, } \\
\qquad 2002\end{array}$ \\
\hline 315 & China Passenger Car Sales & 316 & $\begin{array}{l}\text { U.S. Gasoline and Crude Oil Prices, January 1998- } \\
\text { February } 2004\end{array}$ \\
\hline 317 & State Gasoline Tax Rates & 318 & Biodiesel Gaining in Popularity \\
\hline 319 & $\begin{array}{l}\text { Highway Vehicle Emissions - } 1970 \text { to } 2001 \\
\text { Comparison }\end{array}$ & 320 & The National Highway System \\
\hline 321 & $\begin{array}{c}\text { Days of Reserves Stored in the Strategic Petroleum } \\
\text { Reserve }\end{array}$ & 322 & Hybrid Vehicle Registrations \\
\hline 323 & New Vehicle Attributes & 324 & $\begin{array}{l}\text { Knowledge of Hybrid-Electric Vehicles Continues to } \\
\text { Grow }\end{array}$ \\
\hline 325 & Diesel and Hybrid Vehicle Preferences & 326 & Perception of Diesel Fuel Availability \\
\hline 327 & Paying Extra for Fuel Efficient Vehicles & 328 & Expected Average Annual Miles \\
\hline 329 & How Long Do People Plan to Keep Their Vehicles? & 330 & $\begin{array}{l}\text { Fuel Savings Required to Purchase Fuel Efficient } \\
\text { Vehicle }\end{array}$ \\
\hline 331 & Off-Highway Diesel Fuel Use & 332 & New Light-Vehicle Market Shares, 1976-2003 \\
\hline 333 & Convenience Stores Selling Gasoline & 334 & China is \#2 in Oil Consumption \\
\hline 335 & Diesels Continue to Gain Market Share in Europe & 336 & $\begin{array}{l}\text { World Oil Reserves, Production and Consumption, } \\
2003\end{array}$ \\
\hline 337 & $\begin{array}{c}\text { World Natural Gas Reserves, Production and } \\
\text { Consumption, } 2002\end{array}$ & 338 & What Will Be Used When Gasoline Is Not Available? \\
\hline 339 & $\begin{array}{l}\text { Who Thinks Hydrogen Is the Best Replacement Fuel } \\
\text { for Gasoline? }\end{array}$ & 340 & Hydrogen Fuel as a Replacement for Gasoline \\
\hline 341 & Tire Recycling & 342 & Passenger Car Sales in China \\
\hline 343 & Reasons for Rejecting a Particular New Car Model & 344 & Refueling Stations \\
\hline
\end{tabular}




\begin{tabular}{|c|c|c|c|}
\hline Number & Fact Title & Number & Fact Title \\
\hline 345 & Vehicle Miles Traveled and the Price of Gasoline & 346 & What Is Made from a Barrel of Crude Oil? \\
\hline 347 & The Relationship of VMT and GDP & 348 & U.S. Trade Deficit, $2001-2003$ \\
\hline 349 & $\begin{array}{c}\text { Crude Oil Production: OPEC, the Persian Gulf, and the } \\
\text { United States }\end{array}$ & 350 & U.S. Oil Imports: Top Ten Countries of Origin \\
\hline 351 & Gasohol Use Is Up & 352 & Automotive Industry Material Usage \\
\hline 353 & U.S. Production of Crude Oil by State & 354 & Gasoline Sales by Grade \\
\hline 355 & Comparison of Fuel Prices & 356 & Trucks and Truck-Miles \\
\hline 357 & Growth in Light Truck Registrations & 358 & Trucks by Weight Class, 1997 and 2002 \\
\hline 359 & The Petroleum Gap & 360 & $\begin{array}{c}\text { Vehicles per Thousand People: United States } \\
\text { Compared with Other Countries }\end{array}$ \\
\hline 361 & Fuel Wasted by Congestion & 362 & $\begin{array}{c}\text { Import Share of Petroleum Consumption at All-Time } \\
\text { High }\end{array}$ \\
\hline 363 & Heavy Truck Miles by Age & 364 & Historical Gas Prices, 1919-2004 \\
\hline 365 & The Cost of Driving a Car & 366 & All-Wheel Drive - A Popular Feature on New Cars \\
\hline 367 & State Average Fuel Prices, 2003, 2004, and 2005 & 368 & Truck Fuel Types \\
\hline 369 & Medium-Truck Miles by Age & 370 & $\begin{array}{c}\text { How the Price of Gasoline Relates to Vehicle Miles } \\
\text { Traveled }\end{array}$ \\
\hline 371 & Electronic Features on Heavy Trucks & 372 & Truck Fuel Economy by Size Class \\
\hline 373 & Refueling Practices by Truck Fleet Size & 374 & Refueling Practices by Truck Size \\
\hline 375 & Imported Crude Oil: Where Does It Come From? & 376 & $\begin{array}{l}\text { U.S. Oil Consumption Over } 20 \text { Million Barrels per Day } \\
\text { in } 2004\end{array}$ \\
\hline 377 & New Vehicle Purchase Preference & 378 & Trends in Vehicle Attribute Preference \\
\hline 379 & $\begin{array}{l}\text { Importance of Fuel Economy When Purchasing a } \\
\text { Vehicle }\end{array}$ & 380 & $\begin{array}{l}\text { World Oil Reserves, Production, and Consumption, } \\
2004\end{array}$ \\
\hline 381 & Hybrid Vehicle Registrations, 2000-2004 & 382 & $\begin{array}{c}\text { New Medium and Heavy Truck Registrations by Fuel } \\
\text { Type, } 2004\end{array}$ \\
\hline 383 & U.S. Light Vehicle Manufacturing Locations, 2004 & 384 & The National Highway System, 2003 \\
\hline 385 & Growth in Telecommuting & 386 & $\begin{array}{c}\text { Diesel Car Sales Continue to Thrive in Western } \\
\text { Europe }\end{array}$ \\
\hline 387 & $\begin{array}{l}\text { Light Vehicle Market Share by Size Class, 1975- } \\
\qquad 2005\end{array}$ & 388 & Proposed Light Truck CAFE Standards \\
\hline 389 & More Gasoline Stations in 2005 & 390 & Stretch Commuting \\
\hline 391 & Miles Traveled by Age of Driver & 392 & Household Vehicle Ownership \\
\hline 393 & More Interest in Diesel Engines & 394 & Fuel to Replace Gasoline and Diesel Fuel \\
\hline 395 & Effect of High Gasoline Prices on Consumers & 396 & $\begin{array}{l}\text { Public Perceptions about the Seriousness of Selected } \\
\text { Environmental and Economic Problems }\end{array}$ \\
\hline 397 & Petroleum Import Share & 398 & Effect of High Gasoline Prices on Older Adults \\
\hline 399 & The "Fair" Price of Gasoline & 400 & Model Year 2006 Fuel Economy and Fuel Cost \\
\hline 401 & Actions Taken Due to Traffic Congestion & 402 & $\begin{array}{c}\text { Reasons for Alternative Transportation for } \\
\text { Commuting }\end{array}$ \\
\hline 403 & Travel Changes Due to Rising Cost of Gasoline & 404 & $\begin{array}{l}\text { Better Fuel Economy is Important to Pickup Truck } \\
\text { Owners }\end{array}$ \\
\hline 405 & Pickups Off-Road & 406 & Pickups and Towing \\
\hline 407 & $\begin{array}{l}\text { Vehicle Fuel Cost vs. Home Heating Cost: Which } \\
\text { Causes More Concern? }\end{array}$ & 408 & Perceptions on Energy Reduction \\
\hline 409 & Personal vs. Business Use of Pickup Trucks & 410 & Maximum Speed Limits by State, 2005 \\
\hline 411 & States that Allow Longer Combination Vehicles & 412 & $\begin{array}{l}\text { Freight Activity by Mode Share: U.S. Compared to } \\
\text { Other Countries }\end{array}$ \\
\hline 413 & $\begin{array}{c}\text { Diesels Claim Nearly Half of the Market in Western } \\
\text { Europe }\end{array}$ & 414 & The Petroleum Gap \\
\hline 415 & Changes in Vehicles per Capita around the World & 416 & Consumer Views on Gasoline Taxes \\
\hline 417 & Why Purchase a Hybrid Vehicle? & 418 & $\begin{array}{l}\text { Consumer Preference on Gasoline Tax vs. Fuel } \\
\text { Economy Regulation }\end{array}$ \\
\hline 419 & Freight Ton-Mile Trends by Mode & 420 & Driving Less Due to Gasoline Prices \\
\hline 421 & Knowledge about Hydrogen and Fuel Cells & 422 & Hydrogen Education \\
\hline 423 & Opinions on Hydrogen Fueling Stations & 424 & Important Factors When Selecting a Fuel Supply \\
\hline 425 & $\begin{array}{l}\text { The Price of Gasoline and Vehicle Travel: How Do } \\
\text { They Relate? }\end{array}$ & 426 & The Big Picture on Gasoline Prices \\
\hline 427 & Transportation and the U.S. Trade Deficit, 2001-2005 & 428 & Light Vehicle Tax Credits \\
\hline 429 & $\begin{array}{c}\text { Gross Domestic Product and Vehicle Travel: How Do } \\
\text { They Relate? }\end{array}$ & 430 & Trends in Vehicle Attribute Preference \\
\hline 431 & Would You Buy a Hybrid Vehicle? & 432 & $\begin{array}{l}\text { World Oil Reserves, Production, and Consumption, } \\
2005\end{array}$ \\
\hline 433 & Road Congestion & 434 & Scrap Tire Recycling \\
\hline 435 & Where Do Scrapped Tires Go? & 436 & Interstate Travel \\
\hline 437 & Motorcycle Sales Are Up & 438 & China's New Car Registrations \\
\hline 439 & U.S. Production of Crude Oil by State & 440 & Public Attitude on Hybrids 2005 \\
\hline
\end{tabular}




\begin{tabular}{|c|c|c|c|}
\hline Number & Fact Title & Number & Fact Title \\
\hline 441 & Knowledge about E85 & 442 & Automotive Parts Trade between the U.S. and China \\
\hline 443 & Motor Vehicle Trade between the U.S. and China & 444 & Opinions on Plug-In Hybrid Vehicles \\
\hline 445 & U.S. Population Growth and Light Vehicle Sales & 446 & $\begin{array}{c}\text { More Likely to Buy a Hybrid or Other More Fuel } \\
\text { Efficient Vehicle? }\end{array}$ \\
\hline 447 & World Ethanol Production & 448 & Fuel Purchasing Habits \\
\hline 449 & $\begin{array}{c}\text { Biodiesel to Conventional Diesel: An Emissions } \\
\text { Comparison }\end{array}$ & 450 & Information Sources for First-Time Car Buyers \\
\hline 451 & Household Vehicle Trips & 452 & Driving Differences \\
\hline 453 & Household Vehicle Ownership & 454 & $\begin{array}{l}\text { Relationship between Vehicle Miles and the Number } \\
\text { of Vehicles in a Household }\end{array}$ \\
\hline 455 & Household Vehicle Miles & 456 & Oil Imports, Today and Tomorrow \\
\hline 457 & Long Lines to Buy Gasoline are a Top Concern & 458 & Gasoline Price Expectations \\
\hline 459 & Best and Worst Fuel to Replace Gasoline & 460 & $\begin{array}{l}\text { Regional Differences on Best Fuel to Replace } \\
\text { Gasoline }\end{array}$ \\
\hline 461 & New and Used Light Vehicle Sales & 462 & Historical U.S. Hybrid Vehicle Sales \\
\hline 463 & $\begin{array}{c}\text { Transportation is a Large Share of Average } \\
\text { Household Expenditures }\end{array}$ & 464 & Carbon Dioxide Emissions \\
\hline 465 & The Petroleum Gap & 466 & The Trade Value of Petroleum \\
\hline 467 & Refueling Stations & 468 & World Petroleum Use \\
\hline 469 & $\begin{array}{c}\text { Growth in Per Capita Rates for Vehicles and Vehicle- } \\
\text { Miles }\end{array}$ & 470 & Biodiesel Sales \\
\hline 471 & Biodiesel Production Facilities & 472 & The Causes of Traffic Congestion \\
\hline 473 & Vehicle-Miles per Licensed Driver & 474 & Changes in Vehicles per Capita around the World \\
\hline 475 & Light Vehicle Weight on the Rise & 476 & One Million Toyota Hybrids Worldwide \\
\hline 477 & E-85 Stations by State & 478 & U.S. Carbon Dioxide Emissions by Sector \\
\hline 479 & U.S. Carbon Dioxide Emissions by Sector, 1990-2006 & 480 & Japan is the Top Vehicle Producer \\
\hline 481 & Diesel Car Sales Top Gasoline Car Sales in Europe & 482 & Refinery Output by World Region \\
\hline 483 & Dealer Survey on Small Car Sales & 484 & Trends in Vehicle Attribute Preference \\
\hline 485 & Engine Preferences & 486 & Teleworking Trends \\
\hline 487 & $\begin{array}{l}\text { World Oil Reserves, Production, and Consumption, } \\
2006\end{array}$ & 488 & $\begin{array}{c}\text { World Natural Gas Reserves, Production, and } \\
\text { Consumption, } 2005\end{array}$ \\
\hline 489 & Share of Travel in Congested Conditions & 490 & Traffic Congestion Wastes Fuel \\
\hline 491 & $\begin{array}{c}\text { Gasoline Prices: U.S. and Selected European } \\
\text { Countries }\end{array}$ & 492 & Gasoline Taxes in the U.S. and Selected Countries \\
\hline 493 & Market Share - Cars vs. Light Trucks & 494 & European Priorities When Buying a New Car \\
\hline 495 & Oil Price and Economic Growth, 1971-2006 & 496 & $\begin{array}{l}\text { Diesel Prices in the U.S. and Selected Countries: Cost } \\
\text { and Taxes }\end{array}$ \\
\hline 497 & $\begin{array}{c}\text { Fuel Drops to Third Place in the Trucking Industry Top } \\
\text { Ten Concerns }\end{array}$ & 498 & New Light Vehicle Fuel Economy \\
\hline 499 & Alternative Fuel Models: Gains and Losses & 500 & China is Second Largest in Vehicle Sales \\
\hline 501 & $\begin{array}{l}\text { Fuel Economy and Annual Fuel Ranges for Vehicle } \\
\text { Classes }\end{array}$ & 502 & $\begin{array}{c}\text { Off-Road Diesel Equipment Facing Tougher Emissions } \\
\text { Regulation }\end{array}$ \\
\hline 503 & $\begin{array}{l}\text { EPA Revamps Test Procedures and Raises the Bar for } \\
\text { Fuel Efficiency Ratings on Light Duty Vehicles }\end{array}$ & 504 & $\begin{array}{l}\text { Advancements in Automotive Technology Have } \\
\text { Favored Performance over Fuel Economy }\end{array}$ \\
\hline 505 & $\begin{array}{c}\text { Developing Economies are Rapidly Increasing Their } \\
\text { Petroleum Consumption }\end{array}$ & 506 & $\begin{array}{l}\text { Declining Rate of Highway Fatalities and Injuries is } \\
\text { Good News for Safety and Congestion Mitigation }\end{array}$ \\
\hline 507 & $\begin{array}{l}\text { The Short-Run Price Elasticity of Gasoline Demand } \\
\text { Declined Over the Past Several Decades }\end{array}$ & 508 & $\begin{array}{l}\text { What Consumers Will Do to Save Three Cents per } \\
\text { Gallon }\end{array}$ \\
\hline 509 & $\begin{array}{l}\text { With Rising Gas Prices, Consumers Indicate only a } \\
\text { Limited Willingness to Change Travel Behavior }\end{array}$ & 510 & $\begin{array}{l}\text { Eastern Europe Experiences Strong Growth in Light } \\
\text { Vehicle Sales While Sales in Western Europe Remain } \\
\text { Flat }\end{array}$ \\
\hline 511 & $\begin{array}{l}\text { Hybrid and Flex-fuel Vehicles Increase while Diesels } \\
\text { Experience a Decline }\end{array}$ & 512 & Sales Price for Diesel and Gasoline, 1995-2007 \\
\hline 513 & Transportation and the U.S. Trade Deficit, 2001-2007 & 514 & Historical U.S. Hybrid Vehicle Sales \\
\hline 515 & $\begin{array}{c}\text { The Transportation Services Index, January 1990- } \\
\text { January } 2008\end{array}$ & 516 & The Petroleum Gap \\
\hline 517 & State Average Gasoline Prices, April 28, 2008 & 518 & Top 10 States for New Hybrid Registrations, 2007 \\
\hline 519 & $\begin{array}{l}\text { One Gallon of Gasoline Produces } 20 \text { Pounds of } \\
\text { Carbon Dioxide }\end{array}$ & 520 & Average Price of a New Car, 1970-2006 \\
\hline 521 & $\begin{array}{l}\text { The Price of Gasoline in the United States is } \\
\text { Inexpensive Compared to Most Other Nations }\end{array}$ & 522 & Costs of Oil Dependence 2008 \\
\hline 523 & $\begin{array}{c}\text { Operational Hydrogen Refueling Stations as of } \\
\text { January } 2008\end{array}$ & 524 & $\begin{array}{c}\text { Carbon Footprint of New Light Vehicles Drops } \\
\text { Between } 1975 \text { and } 2007\end{array}$ \\
\hline 525 & $\begin{array}{c}\text { Six and Eight Cylinder Engines are the Most Prevalent } \\
\text { among Light Vehicle Model Offerings for the } 2008 \\
\text { Model Year }\end{array}$ & 526 & $\begin{array}{c}\text { Price Breakdown for a Gallon of Gasoline and a } \\
\text { Gallon of Diesel }\end{array}$ \\
\hline
\end{tabular}




\begin{tabular}{|c|c|c|c|}
\hline Number & Fact Title & Number & Fact Title \\
\hline 527 & $\begin{array}{c}\text { Gross Domestic Product and Vehicle Travel: How Do } \\
\text { They Relate? }\end{array}$ & 528 & $\begin{array}{c}\text { Survey Shows Most Americans Expect Gas Prices to } \\
\text { Reach } \$ 5 \text { This Year }\end{array}$ \\
\hline 529 & Vehicle Production and Sales by World Region & 530 & $\begin{array}{c}\text { Towing Capacity for Selected } 2008 \text { Model Cars and } \\
\text { Trucks }\end{array}$ \\
\hline 531 & Preferences for Hybrids and Diesels & 532 & Trends in Vehicle Attribute Preference \\
\hline 533 & Gasoline Excise Tax Rates by State, 2008 & 534 & Diesel Excise Tax Rates by State, 2008 \\
\hline 535 & Vehicle Miles of Travel (VMT) Declines in 2008 & 536 & $\begin{array}{c}\text { Average Used Car Prices Up and Used Light Truck } \\
\text { Prices Down }\end{array}$ \\
\hline 537 & $\begin{array}{c}\text { Replacing Dual Tires with Single Wide Tires on Class } \\
8 \text { Tractor Trailers Improves Fuel Economy }\end{array}$ & 538 & Crude Oil Price Differences \\
\hline 539 & Light Vehicle Production by State & 540 & Gasoline Prices Adjusted for Inflation \\
\hline 541 & New Car Prices: The Past 100 Years & 542 & Transit Trips Increase in 2008 \\
\hline 543 & Vehicle Trips to Work & 544 & New Vehicle Leasing, 1997-2007 \\
\hline 545 & $\begin{array}{l}\text { Historical Alternative Fuel Prices Compared to } \\
\text { Gasoline and Diesel }\end{array}$ & 546 & $\begin{array}{c}\text { Automotive Sales Down in all Major World Markets for } \\
\text { the Third Quarter of } 2008\end{array}$ \\
\hline 547 & $\begin{array}{l}\text { Research and Development (R\&D) Spending in the } \\
\text { Automotive Industry }\end{array}$ & 548 & $\begin{array}{l}\text { Number of Gasoline Stations Continues to Decline in } \\
\qquad 2007\end{array}$ \\
\hline 549 & $\begin{array}{l}\text { Biofuels Corridor extends from the Great Lakes to the } \\
\text { Gulf of Mexico }\end{array}$ & 550 & Clean Cities Coalitions \\
\hline 551 & Truck Stop Electrification Sites & 552 & Vehicle Miles of Travel by Region \\
\hline 553 & Market Share of New Cars vs. Light Trucks & 554 & Energy Intensity of Light Rail Transit Systems \\
\hline 555 & Transit Buses are Relying Less on Diesel Fuel & 556 & Change in Material Content of Light Vehicles \\
\hline 557 & Change in New Car Dealerships by State & 558 & Transit Vehicle Age and Cost \\
\hline 559 & Light Vehicle Sales per Dealership & 560 & The Transportation Petroleum Gap \\
\hline 561 & All Sectors' Petroleum Gap & 562 & Carbon Reduction of Plug-in Hybrid Electric Vehicles \\
\hline 563 & OPEC Petroleum Imports & 564 & $\begin{array}{l}\text { Transportation and the Gross Domestic Product, } \\
\qquad 2007\end{array}$ \\
\hline 565 & Household Gasoline Expenditures by Income & 566 & Vehicle Travel and the Price of Gasoline \\
\hline 567 & Cars are Growing Older & 568 & $\begin{array}{c}\text { For Modern Cars, Replacing an Air Filter Will Improve } \\
\text { Performance but Not Fuel Economy }\end{array}$ \\
\hline 569 & Gasoline Prices Around the World & 570 & Automotive Manufacturing Employment Declining \\
\hline 571 & Light Truck CAFE Standards - 2006 Reformation & 572 & CAFE Standards for Model Year 2011 \\
\hline 573 & Vehicles per Capita by State & 574 & Vehicles per Licensed Driver Rising \\
\hline 575 & Diesel Car Sales in Europe Still Over 50\% in 2008 & 576 & Carbon Dioxide from Gasoline and Diesel Fuel \\
\hline 577 & Changes in Vehicles per Capita around the World & 578 & $\begin{array}{l}\text { World Oil Reserves, Production, and Consumption, } \\
\qquad 2007\end{array}$ \\
\hline 579 & Oil Price and Economic Growth, 1970-2008 & 580 & Traffic Congestion Grows \\
\hline 581 & Fuel Wasted in Traffic Congestion & 582 & Energy Shares by Sector and Source \\
\hline 583 & Teleworking Trends & 584 & $\begin{array}{c}\text { The Price of Gasoline and Vehicle Travel: How Do } \\
\text { They Relate? }\end{array}$ \\
\hline 585 & Trends in Vehicle Attribute Preference & 586 & New Vehicle Fuel Economies by Vehicle Type \\
\hline 587 & $\begin{array}{l}\text { Cash for Clunkers Program - Fuel Economy } \\
\text { Improvement }\end{array}$ & 588 & Fuel Economy Changes Due to Ethanol Content \\
\hline 589 & $\begin{array}{c}\text { Proposed Fuel Economy and Greenhouse Gas } \\
\text { Emissions Standards }\end{array}$ & 590 & Transit Ridership Still Strong in 2009 \\
\hline 591 & $\begin{array}{c}\text { Consumer Reports Tests Vehicle Fuel Economy by } \\
\text { Speed }\end{array}$ & 592 & The Trade Value of Petroleum \\
\hline 593 & $\begin{array}{c}\text { Petroleum Accounts for Nearly Half of the Total Trade } \\
\text { Deficit }\end{array}$ & 594 & $\begin{array}{l}\text { Fuel Economy and Annual Fuel Cost Ranges for } \\
\text { Vehicle Classes }\end{array}$ \\
\hline 595 & $\begin{array}{l}\text { Plug-in Hybrid Vehicle Purchases May Depend on Fuel } \\
\text { Savings and Incremental Cost }\end{array}$ & 596 & Best and Worst Fuel to Replace Gasoline \\
\hline 597 & Median Age of Cars and Trucks Rising in 2008 & 598 & Hybrid Vehicle Sales by Model \\
\hline 599 & Historical Trend for Light Vehicle Sales & 600 & China Produced More Vehicles than the U.S. in 2008 \\
\hline 601 & World Motor Vehicle Production & 602 & $\begin{array}{c}\text { Freight Statistics by Mode, } 2007 \text { Commodity Flow } \\
\text { Survey }\end{array}$ \\
\hline 603 & Where Does Lithium Come From? & 604 & HOT Lanes in the U.S. \\
\hline 605 & Light Vehicle Sales by Month, 2008-2009 & 606 & New Vehicles Trend Toward Smaller Engines \\
\hline 607 & Energy and Power by Battery Type & 608 & Changes in Greenhouse Gas Emissions since 1990 \\
\hline 609 & The Transportation Petroleum Gap & 610 & All Sectors' Petroleum Gap \\
\hline 611 & Top Ten Best Selling Cars and Light Trucks & 612 & The Distance of Trips to Work \\
\hline 613 & Vehicle Occupancy Rates & 614 & Average Age of Household Vehicles \\
\hline 615 & Average Vehicle Trip Length & 616 & Household Vehicle-Miles of Travel by Trip Purpose \\
\hline 617 & Changes in Vehicles per Capita around the World & 618 & $\begin{array}{c}\text { Vehicles per Household and Other Demographic } \\
\text { Statistics }\end{array}$ \\
\hline 619 & Transportation Sector Revenue by Industry & 620 & Class 8 Truck Tractor Weight by Component \\
\hline 621 & Gross Vehicle Weight vs. Empty Vehicle Weight & 622 & Average Length of Light Vehicle Ownership \\
\hline
\end{tabular}




\begin{tabular}{|c|c|c|c|}
\hline Number & Fact Title & Number & Fact Title \\
\hline 623 & Classification Changes in the CAFE Standards & 624 & $\begin{array}{l}\text { Corporate Average Fuel Economy Standards, Model } \\
\text { Years 2012-2016 }\end{array}$ \\
\hline 625 & Distribution of Trucks by On-Road Vehicle Weight & 626 & Fuel Economy for Light and Heavy Vehicles \\
\hline 627 & Idle Reduction for Heavy Trucks & 628 & Truck Stop Electrification Sites \\
\hline 629 & Top Ten Misconceptions about Fuel Economy & 630 & Fuel Economy vs. Weight and Performance \\
\hline 631 & Top 10 All-Time EPA Rated Vehicles & 632 & The Costs of Oil Dependence \\
\hline 633 & Alternative Fuel Vehicles & 634 & Off-highway Transportation-related Fuel Consumption \\
\hline 635 & Fuel Consumption from Lawn and Garden Equipment & 636 & Transportation Energy Use by Mode \\
\hline 637 & World Motor Vehicle Production & 638 & $\begin{array}{l}\text { Average Expenditure for a New Car Declines in } \\
\text { Relation to Family Earnings }\end{array}$ \\
\hline 639 & Gasoline Tax Rates by State & 640 & Monthly Trends in Vehicle Miles of Travel \\
\hline 641 & Top States for the Production of Cars and Trucks & 642 & Material Content per Light Vehicle, 1995 and 2008 \\
\hline 643 & Four Cylinder Engine Installations Continue to Rise & 644 & $\begin{array}{c}\text { Share of Diesel Vehicle Sales Decline in Western } \\
\text { Europe }\end{array}$ \\
\hline 645 & Price of Diesel versus Gasoline in Europe & 646 & $\begin{array}{l}\text { Prices for Used Vehicles Rise Sharply from } 2008 \text { to } \\
\qquad 2010\end{array}$ \\
\hline 647 & Sales Shifting from Light Trucks to Cars & 648 & Conventional and Alternative Fuel Prices \\
\hline 649 & $\begin{array}{c}\text { Number of New Light Vehicle Dealerships Continues } \\
\text { to Shrink }\end{array}$ & 650 & Diesel Fuel Prices hit a Two-Year High \\
\hline 651 & $\begin{array}{l}\text { Hybrid Vehicles Dominate EPA's Top Ten Fuel Sippers } \\
\text { List for } 2011\end{array}$ & 652 & U.S. Crude Oil Production Rises \\
\hline 653 & Import Cars and Trucks Gaining Ground & 654 & New Light Vehicle Leasing is Big in 2010 \\
\hline 655 & New Freight Analysis Tool & 656 & Consumers Hold onto Vehicles Longer \\
\hline 657 & Record Increase for New Light Vehicle Fuel Economy & 658 & $\begin{array}{l}\text { Increasing Use of Vehicle Technologies to Meet Fuel } \\
\text { Economy Requirements }\end{array}$ \\
\hline 659 & $\begin{array}{l}\text { Fuel Economy Ratings for Vehicles Operating on } \\
\text { Electricity }\end{array}$ & 660 & Light Vehicle Sales Rise in 2010 \\
\hline 661 & Population Density & 662 & World Biodiesel Production \\
\hline 663 & $\begin{array}{c}\text { Clean Cities Program Petroleum Displacement } \\
\text { Estimates for } 2009\end{array}$ & 664 & 2010 U.S. Petroleum Imports by Country \\
\hline 665 & Garage Availability for Plug-in Vehicles & 666 & Survey says Electric Vehicle Prices are Key \\
\hline 667 & Fuel Wasted in Traffic Congestion & 668 & Time Wasted Due to Traffic Congestion \\
\hline 669 & GM Sells More Vehicles in China than in the U.S. & 670 & Vehicle-Miles of Travel Rises in 2010 \\
\hline 671 & Average Truck Speeds & 672 & Freight Gateways in the U.S. \\
\hline 673 & U.S. Trade Balance for Transportation Vehicles & 674 & Petroleum Trade Balance \\
\hline 675 & Gasoline Prices by Region, May 2, 2011 & 676 & $\begin{array}{l}\text { U.S. Refiners Produce about } 19 \text { Gallons of Gasoline } \\
\text { from a Barrel of Oil }\end{array}$ \\
\hline 677 & Number of Hybrid Models, 2001-2011 & 678 & Manufacturer Market Share of Hybrid Vehicles, 2010 \\
\hline 679 & U.S. Imports of Fuel Ethanol Drop Sharply & 680 & $\begin{array}{c}\text { Fuel Economy is "Most Important" When Buying a } \\
\text { Vehicle }\end{array}$ \\
\hline 681 & U.S. Ethanol Production, 2001-2010 & 682 & Federal Alternative Fuel Use \\
\hline 683 & $\begin{array}{c}\text { Federal Tax Credits for the Purchase of Advanced } \\
\text { Technology Vehicles }\end{array}$ & 684 & Fuel Economy versus Fuel Savings \\
\hline 685 & Reasons for Buying a Plug-in Hybrid Vehicle & 686 & Emissions and Energy Use Model - GREET \\
\hline 687 & The Transportation Petroleum Gap & 688 & All Sectors' Petroleum Gap \\
\hline 689 & Energy Use by Sector and Source & 690 & Characteristics of New Light Vehicles over Time \\
\hline 691 & Mexico Surpassed Canada in Vehicle Production & 692 & $\begin{array}{l}\text { Fuel Economy Distribution for New Cars and Light } \\
\text { Trucks }\end{array}$ \\
\hline 693 & Average Vehicle Footprint for Cars and Light Trucks & 694 & Costs of Owning a Vehicle by State \\
\hline 695 & New Car Dealerships & 696 & Top Ten "Real World" Fuel Economy Leaders \\
\hline 697 & $\begin{array}{c}\text { Comparison of Vehicles per Thousand People in } \\
\text { Selected Countries/Regions }\end{array}$ & 698 & $\begin{array}{c}\text { Changes in the Federal Highway Administration } \\
\text { Vehicle Travel Data }\end{array}$ \\
\hline 699 & $\begin{array}{l}\text { Transportation Energy Use by Mode and Fuel Type, } \\
\qquad 2009\end{array}$ & 700 & Biodiesel Consumption is on the Rise for 2011 \\
\hline 701 & $\begin{array}{c}\text { How Much More Would You Pay for an Electric } \\
\text { Vehicle? }\end{array}$ & 702 & Consumer Preferences on Electric Vehicle Charging \\
\hline 703 & Hybrid Vehicles Lose Market Share in 2010 & 704 & $\begin{array}{l}\text { Fuel Consumption Standards for New Heavy Pickups } \\
\text { and Vans }\end{array}$ \\
\hline 705 & $\begin{array}{c}\text { Fuel Consumption Standards for Combination } \\
\text { Tractors }\end{array}$ & 706 & Vocational Vehicle Fuel Consumption Standards \\
\hline 707 & Illustration of Truck Classes & 708 & $\begin{array}{c}\text { Amenities, Safety and Emissions Equipment Make Up } \\
\text { an Increasing Share of the Cost of a Car }\end{array}$ \\
\hline 709 & Engine Energy Use: Where Does the Energy Go? & 710 & $\begin{array}{l}\text { Engine Energy Use for Heavy Trucks: Where Does the } \\
\text { Energy Go? }\end{array}$ \\
\hline 711 & Top Vehicles around the Globe, 2011 & 712 & Top Vehicles in the U.S., 2011 \\
\hline 713 & Light Vehicle Sales Continue to Recover & 714 & Light Truck Sales on the Rise \\
\hline
\end{tabular}




\begin{tabular}{|c|c|c|c|}
\hline Number & Fact Title & Number & Fact Title \\
\hline 715 & The Average Age of Light Vehicles Continues to Rise & 716 & $\begin{array}{c}\text { Diesels are more than Half of New Cars Sold in } \\
\text { Western Europe }\end{array}$ \\
\hline 717 & $\begin{array}{l}\text { Availability of Electric Charging Stations Has } \\
\text { Increased Dramatically in Recent Years }\end{array}$ & 718 & $\begin{array}{l}\text { Number of Flex-Fuel Models Offered Increased in } \\
2011\end{array}$ \\
\hline 719 & $\begin{array}{c}\text { Nearly } 14 \% \text { of New Car Sales have Continuously } \\
\text { Variable Transmissions }\end{array}$ & 720 & $\begin{array}{c}\text { Eleven Percent of New Light Trucks Sold have } \\
\text { Gasoline Direct Injection }\end{array}$ \\
\hline 721 & Heavy Trucks Move Freight Efficiently & 722 & Hybrid Vehicles Can Save Money over Time \\
\hline 723 & $\begin{array}{l}\text { Japan's Earthquake and Tsunami Resulted in Major } \\
\text { Losses for Japanese Automakers }\end{array}$ & 724 & $\begin{array}{c}\text { Gas Guzzler Tax Levied on New Cars with Low Fuel } \\
\text { Economy }\end{array}$ \\
\hline 725 & $\begin{array}{c}\text { Cylinder Deactivation is More Prevalent in Light } \\
\text { Trucks than Cars }\end{array}$ & 726 & SUVs: Are They Cars or Trucks? \\
\hline 727 & $\begin{array}{c}\text { Nearly Twenty Percent of Households Own Three or } \\
\text { More Vehicles }\end{array}$ & 728 & Average Trip Length is Less Than Ten Miles \\
\hline 729 & Secondary Household Vehicles Travel Fewer Miles & 730 & $\begin{array}{l}\text { Fuel Economy of New Light Vehicles is Up 19\% from } \\
\qquad 1980 \text { to } 2011\end{array}$ \\
\hline 731 & $\begin{array}{c}\text { Cost-Effectiveness of a Hybrid Vehicle is Highly } \\
\text { Conditional }\end{array}$ & 732 & Days to Turn Trend by Vehicle Class \\
\hline 733 & World's Top Petroleum-Producing Countries & 734 & $\begin{array}{l}\text { OPEC Countries Represent Less Than Half of U.S. } \\
\text { Petroleum Imports }\end{array}$ \\
\hline 735 & U.S. Petroleum Exports Are on the Rise & 736 & $\begin{array}{c}\text { Total Petroleum Imports and Net Petroleum Imports: } \\
\text { The Difference is Growing }\end{array}$ \\
\hline 737 & Upstream Emissions for Nissan Leaf & 738 & Number of New Light Vehicle Dealerships Decreasing \\
\hline 739 & $\begin{array}{l}\text { Light Vehicle Dealership Sales Trends - New } \\
\text { Vehicles, Used Vehicles, and Service/Parts }\end{array}$ & 740 & Interest in Smaller Vehicles is on the Rise \\
\hline 741 & Historical Gasoline Prices, 1929-2011 & 742 & Oil Price and Economic Growth \\
\hline 743 & $\begin{array}{c}\text { Used Vehicle Sales are Three Times Higher than New } \\
\text { Vehicle Sales }\end{array}$ & 744 & $\begin{array}{c}\text { Average New Light Vehicle Price Grows Faster than } \\
\text { Average Used Light Vehicle Price }\end{array}$ \\
\hline 745 & $\begin{array}{c}\text { Vehicles per Thousand People: U.S. Compared to } \\
\text { Other Countries }\end{array}$ & 746 & U.S. Share of World Vehicles Declines \\
\hline 747 & $\begin{array}{c}\text { Behind Housing, Transportation is the Top Household } \\
\text { Expenditure }\end{array}$ & 748 & $\begin{array}{c}\text { Components of Household Expenditures on } \\
\text { Transportation, 1984-2010 }\end{array}$ \\
\hline 749 & $\begin{array}{c}\text { Petroleum and Natural Gas Consumption for } \\
\text { Transportation by State, } 2010\end{array}$ & 750 & $\begin{array}{l}\text { Electric Vehicle Energy Requirements for Combined } \\
\text { City/Highway Driving }\end{array}$ \\
\hline 751 & $\begin{array}{l}\text { Plug-in Car Sales Higher in the U.S. Compared to } \\
\text { Western Europe and China }\end{array}$ & 752 & Western Europe Plug-in Car Sales, 2012 \\
\hline 753 & Sources of Electricity by State & 754 & Vehicle Sales in the U.S. and China, 2002-2011 \\
\hline 755 & $\begin{array}{l}\text { Chargepoint, Blink and Nissan Take the Lead in } \\
\text { Public Electric Vehicle Chargers }\end{array}$ & 756 & Midwest Produces Two-Thirds of All Light Vehicles \\
\hline 757 & The U.S. Manufactures More Light Trucks than Cars & 758 & U.S. Production of Crude Oil by State, 2011 \\
\hline 759 & Rural vs. Urban Driving Differences & 760 & Commuting to Work, $1960-2010$ \\
\hline 761 & $\begin{array}{l}\text { Smaller Share of Teenagers Have a Driver's License } \\
\text { in } 2010\end{array}$ & 762 & $\begin{array}{c}\text { Sales from Introduction: Hybrid Vehicles vs. Plug-in } \\
\text { Vehicles }\end{array}$ \\
\hline 763 & Eighty-four Percent of Scrapped Tires Are Recycled & 764 & $\begin{array}{l}\text { Model Year } 2013 \text { Brings More Fuel Efficient Choices } \\
\text { for Consumers }\end{array}$ \\
\hline 765 & $\begin{array}{c}\text { EPA's Top } 10 \text { Conventionally-Fueled Vehicles for } \\
\text { Model Year } 2013\end{array}$ & 766 & $\begin{array}{l}\text { Electricity Prices are More Stable than Gasoline } \\
\text { Prices }\end{array}$ \\
\hline 767 & Federal Excise Tax on Gasoline, 1932 - 2012 & 768 & New Light Vehicle Sales and Gross Domestic Product \\
\hline 769 & Monthly Trend in Light Vehicle Sales, 2008-2012 & 770 & $\begin{array}{c}\text { Changes to the Top Ten Vehicles Sold over the Last } \\
\text { Five Years }\end{array}$ \\
\hline 771 & $\begin{array}{c}\text { California Zero-Emission Vehicle Mandate is Now in } \\
\text { Effect }\end{array}$ & 772 & Fuel Economy by Speed: Slow Down to Save Fuel \\
\hline 773 & Fuel Economy Penalty at Higher Speeds & 774 & Fuel Wasted in Traffic Congestion \\
\hline 775 & $\begin{array}{c}\text { Top Ten Urban Areas for Fuel Wasted due to Traffic } \\
\text { Congestion, } 2011\end{array}$ & 776 & $\begin{array}{l}\text { Fuel Savings from Attempts to Alleviate Traffic } \\
\text { Congestion }\end{array}$ \\
\hline 777 & $\begin{array}{c}\text { For the Second Year in a Row, Survey Respondents } \\
\text { Consider Fuel Economy Most Important When } \\
\text { Purchasing a Vehicle }\end{array}$ & 778 & $\begin{array}{c}\text { Vehicles per Thousand Persons Rising Quickly in } \\
\text { China and India }\end{array}$ \\
\hline 779 & $\begin{array}{l}\text { EPA's Top Ten Rated Vehicles List for Model Year } \\
2013 \text { is All Electric }\end{array}$ & 780 & Crude Oil Reserve to Production Ratio \\
\hline 781 & Top Ten Natural Gas Producing Countries & 782 & Number of Refueling Stations Continues to Shrink \\
\hline 783 & Emissions and Energy Use Model - GREET & 784 & $\begin{array}{l}\text { Direct Employment of Motor Vehicle Parts } \\
\text { Manufacturing by State }\end{array}$ \\
\hline 785 & Many Cars Pollute Less Despite Increases in Size & 786 & Use of Lightweight Materials is on the Rise \\
\hline 787 & $\begin{array}{c}\text { Truck Stop Electrification Reduces Idle Fuel } \\
\text { Consumption }\end{array}$ & 788 & $\begin{array}{c}\text { State and Private Consumer Incentives for Plug-In } \\
\text { Vehicles }\end{array}$ \\
\hline 789 & $\begin{array}{c}\text { Comparison of State Incentives for Plug-In Electric } \\
\text { Vehicle Purchases }\end{array}$ & 790 & $\begin{array}{c}\text { States Beginning to Tax Electric Vehicles for Road } \\
\text { Use }\end{array}$ \\
\hline 791 & Comparative Costs to Drive an Electric Vehicle & 792 & $\begin{array}{l}\text { Energy Consumption by Sector and Energy Source, } \\
\qquad 1982 \text { and } 2012\end{array}$ \\
\hline
\end{tabular}




\begin{tabular}{|c|c|c|c|}
\hline Number & Fact Title & Number & Fact Title \\
\hline 793 & $\begin{array}{c}\text { Improvements in Fuel Economy for Low-MPG Vehicles } \\
\text { Yield the Greatest Fuel Savings }\end{array}$ & 794 & $\begin{array}{c}\text { How Much Does an Average Vehicle Owner Pay in } \\
\text { Fuel Taxes Each Year? }\end{array}$ \\
\hline 795 & Electric Vehicle Charging Stations by State & 796 & $\begin{array}{l}\text { Electric Vehicle and Plug-In Hybrid Electric Vehicle } \\
\text { Sales History }\end{array}$ \\
\hline 797 & Driving Ranges for Electric Vehicles & 798 & Plug-in Hybrid Vehicle Driving Range \\
\hline 799 & Electricity Generation by Source, $2003-2012$ & 800 & Characteristics of New Light Vehicles over Time \\
\hline 801 & Gasoline Direct Injection Continues to Grow & 802 & Market Share by Transmission Type \\
\hline 803 & Average Number of Transmission Gears is on the Rise & 804 & $\begin{array}{c}\text { Tool Available to Print Used Vehicle Fuel Economy } \\
\text { Window Stickers }\end{array}$ \\
\hline 805 & Vehicle Technology Penetration & 806 & $\begin{array}{l}\text { Light Vehicle Market Shares, Model Years 1975- } \\
\qquad 2012\end{array}$ \\
\hline 807 & Light Vehicle Weights Leveling Off & 808 & Declining Use of Six- and Eight-Cylinder Engines \\
\hline 809 & What Do We Pay for in a Gallon of Gasoline? & 810 & Leasing on the Rise \\
\hline 811 & Light Vehicle Sales Recoveries & 812 & $\begin{array}{l}\text { The Number of Models Achieving } 40 \text { MPG or More is } \\
\text { Increasing Rapidly }\end{array}$ \\
\hline 813 & New Light Vehicle Fuel Economy Continues to Rise & 814 & $\begin{array}{l}\text { More Choices when Buying Vehicles that Use } \\
\text { Advanced Technology and Alternative Fuels }\end{array}$ \\
\hline 815 & Global Sales of Top 10 Plug-In Vehicles & 816 & $\begin{array}{c}\text { Natural Gas Refueling Stations Grow Over the Last } \\
\text { Ten Years }\end{array}$ \\
\hline 817 & $\begin{array}{l}\text { Conventional and Alternative Fuel Price Trends from } \\
2000 \text { to } 2013\end{array}$ & 818 & The Effect of Winter Weather on Fuel Economy \\
\hline 819 & Imports of Crude Oil Declining & 820 & Dollars Spent on Imported Petroleum \\
\hline 821 & Best Selling Vehicle by State, 2013 & 822 & Battery Capacity Varies Widely for Plug-In Vehicles \\
\hline 823 & $\begin{array}{c}\text { Hybrid Vehicles use more Battery Packs but Plug-in } \\
\text { Vehicles use More Battery Capacity }\end{array}$ & 824 & EPA Sulfur Standards for Gasoline \\
\hline 825 & $\begin{array}{l}\text { Tier } 3 \text { Non-Methane Organic Gases Plus Nitrogen } \\
\text { Oxide Emission Standards, Model Years 2017-2025 }\end{array}$ & 826 & The Effect of Tire Pressure on Fuel Economy \\
\hline 827 & $\begin{array}{c}\text { Share of Import Cars Declines to less than } 30 \% \text { of Car } \\
\text { Sales in } 2013\end{array}$ & 828 & $\begin{array}{c}\text { Japanese Auto Manufacturers Increase Domestic } \\
\text { Production for U.S. Sales }\end{array}$ \\
\hline 829 & The Transportation Petroleum Gap & 830 & Diesel Light Vehicle Offerings Expand \\
\hline 831 & Top Ten States with Diesel Light Vehicles & 832 & $\begin{array}{c}\text { Over Half of the Refueling Stations in the U.S. and } \\
\text { Canada Sell Diesel Fuel }\end{array}$ \\
\hline 833 & $\begin{array}{l}\text { Fuel Economy Rated Second Most Important Vehicle } \\
\text { Attribute }\end{array}$ & 834 & $\begin{array}{l}\text { About Two-Thirds of Transportation Energy Use is } \\
\text { Gasoline for Light Vehicles }\end{array}$ \\
\hline 835 & Average Annual Gasoline Pump Price, 1929-2013 & 836 & $\begin{array}{l}\text { Non-OPEC Countries Supply Nearly Two-thirds of U.S. } \\
\text { Petroleum Imports }\end{array}$ \\
\hline 837 & $\begin{array}{c}\text { Gap between Net Imports and Total Imports of } \\
\text { Petroleum is Widening }\end{array}$ & 838 & $\begin{array}{l}\text { Net Imports of Petroleum were Only 33\% of U.S. } \\
\text { Consumption in } 2013\end{array}$ \\
\hline 839 & $\begin{array}{l}\text { World Petroleum Consumption Continues to Rise } \\
\text { despite Declines from the United States and Europe }\end{array}$ & 840 & World Renewable Electricity Consumption is Growing \\
\hline 841 & $\begin{array}{c}\text { Vehicles per Thousand People: U.S. vs. Other World } \\
\text { Regions }\end{array}$ & 842 & $\begin{array}{l}\text { Vehicles and Vehicle Travel Trends have Changed } \\
\text { Since } 2008\end{array}$ \\
\hline 843 & $\begin{array}{l}\text { Cumulative Plug-in Electric Vehicle Sales are Two and } \\
\text { a Half Times Higher than Hybrid Electric Vehicle Sales } \\
\text { in the First } 45 \text { Months since Market Introduction }\end{array}$ & 844 & $\begin{array}{l}\text { Electricity Generated from Coal has Declined while } \\
\text { Generation from Natural Gas has Grown }\end{array}$ \\
\hline 845 & $\begin{array}{c}\text { From } 1970 \text { to } 2013 \text { the Share of Older Vehicles in } \\
\text { Operation has Increased }\end{array}$ & 846 & $\begin{array}{c}\text { Trucks Move } 70 \% \text { of all Freight by Weight and } 74 \% \text { of } \\
\text { Freight by Value }\end{array}$ \\
\hline 847 & $\begin{array}{l}\text { Cars were Over } 50 \% \text { of Light Vehicle Production in } \\
\qquad 2014\end{array}$ & 848 & $\begin{array}{l}\text { Nearly Three-Fourths of New Cars have Fuel Economy } \\
\text { above } 25 \text { Miles per Gallon }\end{array}$ \\
\hline 849 & $\begin{array}{l}\text { Midsize Hybrid Cars Averaged 51\% Better Fuel } \\
\text { Economy than Midsize Non-Hybrid Cars in } 2014\end{array}$ & 850 & $\begin{array}{l}\text { Automatic Transmissions have closed the Fuel } \\
\text { Economy Gap with Manual Transmissions }\end{array}$ \\
\hline 851 & $\begin{array}{c}\text { The Average Number of Gears used in Transmissions } \\
\text { Continues to Rise }\end{array}$ & 852 & $\begin{array}{l}\text { Turbocharged Engines Account for } 64.7 \% \text { of all Four- } \\
\text { Cylinder Gasoline Car Engines in } 2014\end{array}$ \\
\hline 853 & $\begin{array}{c}\text { Stop/Start Technology is in nearly } 5 \% \text { of All New Light } \\
\text { Vehicles Produced }\end{array}$ & 854 & $\begin{array}{l}\text { Driving Ranges for All-Electric Vehicles in Model Year } \\
2014 \text { Vary from } 62 \text { to } 265 \text { Miles }\end{array}$ \\
\hline 855 & Electric Vehicle Chargers by Network and State & 856 & $\begin{array}{c}\text { Plug-in and Hybrid Cars Receive High Scores for } \\
\text { Owner Satisfaction }\end{array}$ \\
\hline 857 & $\begin{array}{l}\text { Number of Partner Workplaces Offering Electric } \\
\text { Vehicle Charging More Than Tripled Since } 2011\end{array}$ & 858 & $\begin{array}{c}\text { Retail Gasoline Prices in } 2014 \text { Experienced the } \\
\text { Largest Decline since } 2008\end{array}$ \\
\hline 859 & $\begin{array}{c}\text { Excess Supply is the Most Recent Event to Affect } \\
\text { Crude Oil Prices }\end{array}$ & 860 & $\begin{array}{c}\text { Relationship of Vehicle Miles of Travel and the Price } \\
\text { of Gasoline }\end{array}$ \\
\hline 861 & $\begin{array}{l}\text { Idle Fuel Consumption for Selected Gasoline and } \\
\text { Diesel Vehicles }\end{array}$ & 862 & $\begin{array}{c}\text { Light Vehicle Production in Mexico More than } \\
\text { Doubled in Last Five Years }\end{array}$ \\
\hline 863 & $\begin{array}{l}\text { Crude Oil Accounts for the Majority of Primary Energy } \\
\text { Imports while Exports are Mostly Petroleum Products }\end{array}$ & 864 & $\begin{array}{l}\text { Imports of Primary Energy have Declined Sharply } \\
\text { Since the Peak Reached in } 2007\end{array}$ \\
\hline 865 & $\begin{array}{l}\text { Over Three-Fourths of all Commuters Drove to Work } \\
\text { Alone in } 2013\end{array}$ & 866 & $\begin{array}{c}\text { Light Vehicles Priced from } \$ 30-35,000 \text { Are the } \\
\text { Biggest Sellers in } 2013\end{array}$ \\
\hline 867 & $\begin{array}{c}\text { Car-Sharing and Ride-Summoning Are a Growing } \\
\text { Phenomenon }\end{array}$ & 868 & $\begin{array}{l}\text { Automotive Technology Has Improved Performance } \\
\text { and Fuel Economy of New Light Vehicles }\end{array}$ \\
\hline
\end{tabular}




\begin{tabular}{|c|c|c|c|}
\hline Number & Fact Title & Number & Fact Title \\
\hline 869 & $\begin{array}{l}\text { Gasoline Direct Injection Captures 38\% Market Share } \\
\text { in Just Seven Years from First Significant Use }\end{array}$ & 870 & $\begin{array}{l}\text { Corporate Average Fuel Economy Progress, 1978- } \\
\qquad 2014\end{array}$ \\
\hline 871 & $\begin{array}{l}\text { Most Manufacturers Have Positive CAFE Credit } \\
\text { Balances at the End of Model Year } 2013\end{array}$ & 872 & $\begin{array}{l}\text { Study Finds More than } 60 \% \text { of Millennials and } \\
\text { Generation Xers Use the Internet to Find a Car Dealer } \\
\text { While Less than Half of Baby Boomers Did }\end{array}$ \\
\hline 873 & $\begin{array}{l}\text { Plug-In Vehicle Sales Total Nearly 120,000 Units in } \\
\qquad 2014\end{array}$ & 874 & $\begin{array}{c}\text { Number of Electric Stations and Electric Charging } \\
\text { Units Increasing }\end{array}$ \\
\hline 875 & Hybrid Electric Vehicle Penetration by State, 2014 & 876 & Plug-in Electric Vehicle Penetration by State, 2014 \\
\hline 877 & $\begin{array}{c}\text { Which States Have More Battery Electric Vehicles } \\
\text { than Plug-in Hybrids? }\end{array}$ & 878 & $\begin{array}{l}\text { Plug-in Vehicle Penetration in Selected Countries, } \\
2014\end{array}$ \\
\hline 879 & $\begin{array}{c}\text { Greenhouse Gas Abatement Costs for Employer- } \\
\text { Subsidized Commuting Options }\end{array}$ & 880 & $\begin{array}{c}\text { Conventional Vehicle Energy Use: Where Does the } \\
\text { Energy Go? }\end{array}$ \\
\hline 881 & Powertrain Efficiency Improvements, 2005 to 2013 & 882 & $\begin{array}{l}\text { Hybrid Vehicle Energy Use: Where Does the Energy } \\
\text { Go? }\end{array}$ \\
\hline 883 & $\begin{array}{l}\text { Hybrid Powertrains are More Efficient than } \\
\text { Conventional Counterparts }\end{array}$ & 884 & All-electric Vehicle: Where Does the Energy Go? \\
\hline 885 & $\begin{array}{c}\text { Electricity Generation - Planned Additions and } \\
\text { Retirements }\end{array}$ & 886 & New Light-Vehicle Leasing Penetration for 2014 \\
\hline 887 & The United States Supplies 15\% of World Petroleum & 888 & Historical Gas Prices \\
\hline 889 & $\begin{array}{c}\text { Average Diesel Price Lower than Gasoline for the First } \\
\text { Time in Six Years }\end{array}$ & 890 & $\begin{array}{c}\text { Gasoline Prices Are Affected by Changes in Refinery } \\
\text { Output }\end{array}$ \\
\hline 891 & $\begin{array}{c}\text { Comparison of State Incentives for Plug-In Electric } \\
\text { Vehicle Purchases }\end{array}$ & 892 & Over One-Million in Plug-in Vehicle Sales Worldwide \\
\hline 893 & $\begin{array}{c}\text { Incentives for the Installation of Electric Vehicle } \\
\text { Charging Stations }\end{array}$ & 894 & $\begin{array}{l}\text { U.S. Petroleum Production and Consumption for All } \\
\text { Sectors, } 1973 \text { through } 2040\end{array}$ \\
\hline 895 & $\begin{array}{l}\text { U.S. Petroleum Production and Consumption: The } \\
\text { Changing Landscape }\end{array}$ & 896 & $\begin{array}{c}\text { More than } 80 \% \text { of Transportation Energy Use is } \\
\text { Highway Fuel Use }\end{array}$ \\
\hline 897 & Fuel Wasted in Traffic Congestion & 898 & World Carbon Dioxide Emissions, 1990-2012 \\
\hline 899 & World Production of Cars and Trucks & 900 & States Tax Gasoline at Varying Rates \\
\hline 901 & $\begin{array}{c}\text { States Assessing Fees on Electric Vehicles to Make } \\
\text { Up for Lost Fuel Tax Revenue }\end{array}$ & 902 & Rural versus Urban Vehicle Miles of Travel by State \\
\hline 903 & Vehicle Miles of Travel is up in 2015 & 904 & $\begin{array}{l}\text { Gross Domestic Product and Vehicle Travel: Both } \\
\text { Increased during } 2015\end{array}$ \\
\hline 905 & $\begin{array}{l}\text { Alternative Fuels Account for One-Third of Transit Bus } \\
\text { Fuel Use }\end{array}$ & 906 & $\begin{array}{l}\text { VMT and the Price of Gasoline Typically Move in } \\
\text { Opposition }\end{array}$ \\
\hline 907 & Light Vehicle Sales at a Record High in 2015 & 908 & Light Vehicle Sales Rise for Five Consecutive Years \\
\hline 909 & $\begin{array}{c}\text { Workplace Charging Accounts for About a Third of All } \\
\text { Plug-in Vehicle Charging Sessions in the INL EV } \\
\text { Project Study }\end{array}$ & 910 & $\begin{array}{c}\text { Study Shows Average Cost of Electric Vehicle Charger } \\
\text { Installations }\end{array}$ \\
\hline 911 & $\begin{array}{c}\text { Workplace Charging Increases VMT of Plug-in } \\
\text { Vehicles in the EV Project }\end{array}$ & 912 & $\begin{array}{c}\text { Plug-in Vehicle Owners Take Advantage of Off-Peak } \\
\text { Charging }\end{array}$ \\
\hline 913 & $\begin{array}{c}\text { The Most Common Warranty for Plug-In Vehicle } \\
\text { Batteries is } 8 \text { Years } 100,000 \text { Miles }\end{array}$ & 914 & Plug-in Vehicle Sales Climb as Battery Costs Decline \\
\hline 915 & $\begin{array}{l}\text { Average Historical Annual Gasoline Pump Price, } \\
\qquad 1929-2015\end{array}$ & 916 & $\begin{array}{l}\text { Fuel Savings/Emissions Reduction was the Top } \\
\text { Reason Cited by Truck Fleet Management for } \\
\text { Adopting Idle Reduction Technologies }\end{array}$ \\
\hline 917 & Work Truck Daily Idle Time by Industry & 918 & $\begin{array}{l}\text { Global Plug-in Light Vehicle Sales Increased by About } \\
\qquad 80 \% \text { in } 2015\end{array}$ \\
\hline 919 & $\begin{array}{l}\text { Plug-in Electric Vehicle Charging Options and Times } \\
\text { Vary Considerably }\end{array}$ & 920 & $\begin{array}{l}\text { Electric Charging Stations are the Fastest Growing } \\
\text { Type of Alternative Fueling Station }\end{array}$ \\
\hline 921 & $\begin{array}{l}\text { Japan Produced the Most Automotive Lithium-ion } \\
\text { Batteries by Capacity in } 2014\end{array}$ & 922 & $\begin{array}{c}\text { Share of Older Population Holding Driver's Licenses is } \\
\text { Up and Share of Younger Population Holding Driver's } \\
\text { Licenses is Down }\end{array}$ \\
\hline 923 & $\begin{array}{l}\text { Cylinder Deactivation was Used in More than a } \\
\text { Quarter of New Light Trucks Produced in } 2015\end{array}$ & 924 & $\begin{array}{c}\text { Twenty Percent of New Cars in } 2015 \text { Had } \\
\text { Turbochargers }\end{array}$ \\
\hline 925 & $\begin{array}{c}\text { Improvements in Fuel Economy for Low-MPG Vehicles } \\
\text { Yield the Greatest Savings }\end{array}$ & 926 & $\begin{array}{l}\text { Petroleum Imports Below } \$ 200 \text { Billion, Lowest Point } \\
\text { in Over a Decade }\end{array}$ \\
\hline 927 & $\begin{array}{c}\text { The United States Imported Over } \$ 70 \text { Billion Worth of } \\
\text { Vehicles and Parts from Mexico in } 2015\end{array}$ & 928 & $\begin{array}{l}\text { Price Difference between Regular and Premium } \\
\text { Gasoline Has Grown Each Year Since } 2011\end{array}$ \\
\hline 929 & Heavy Truck Speed Limits Are Inconsistent & 930 & $\begin{array}{l}\text { Subcompact Plug-in Vehicle Sales Reached } 4 \% \text { of } \\
\text { Subcompact Sales in February } 2015\end{array}$ \\
\hline 931 & $\begin{array}{c}\text { Plug-in Electric Vehicles Were Available in Nine } \\
\text { Different Size Classes in } 2015\end{array}$ & 932 & $\begin{array}{c}\text { Longer Combination Trucks Are Only Permitted on } \\
\text { Some Routes }\end{array}$ \\
\hline 933 & $\begin{array}{l}\text { Texas, North Dakota, and the Gulf of Mexico Account } \\
\text { for Two-Thirds of U.S. Crude Oil Production }\end{array}$ & 934 & $\begin{array}{l}\text { OPEC Accounts for Less than One-third of U.S. } \\
\text { Petroleum Imports }\end{array}$ \\
\hline 935 & $\begin{array}{c}\text { By Volume, Net Petroleum Imports are at Lowest } \\
\text { Point Since } 1985\end{array}$ & 936 & $\begin{array}{l}\text { California Had the Highest Concentration of Plug-in } \\
\text { Vehicles Relative to Population in } 2015\end{array}$ \\
\hline
\end{tabular}




\begin{tabular}{|c|c|c|c|}
\hline Number & Fact Title & Number & Fact Title \\
\hline 937 & $\begin{array}{c}\text { Total Battery Capacity of all Plug-in Electric Vehicles } \\
\text { Sold Increased from } 2014 \text { to } 2015\end{array}$ & 938 & $\begin{array}{c}\text { Median All-Electric Vehicle Range Grew from } 73 \text { Miles } \\
\text { in Model Year } 2011 \text { to } 83.5 \text { Miles in Model Year } \\
2016\end{array}$ \\
\hline 939 & $\begin{array}{l}\text { All-Electric Vehicle Ranges Can Exceed Those of } \\
\text { Some Gasoline Vehicles }\end{array}$ & 940 & $\begin{array}{c}\text { Diverging Trends of Engine Compression Ratio and } \\
\text { Gasoline Octane Rating }\end{array}$ \\
\hline 941 & $\begin{array}{c}\text { Mid-term Evaluation of the Corporate Average Fuel } \\
\text { Economy Standards May Impact Future Standards for } \\
\text { Model Years } 2022 \text { to } 2025\end{array}$ & 942 & $\begin{array}{l}\text { Fifteen Percent of Survey Respondents Consider Fuel } \\
\text { Economy Most Important when Purchasing a Vehicle }\end{array}$ \\
\hline 943 & $\begin{array}{l}\text { Fuel Economy Being Chosen as the Most Important } \\
\text { Vehicle Attribute is Related to the Price of Gasoline }\end{array}$ & 944 & $\begin{array}{l}\text { Public Opinion of Fuels Which Could Replace } \\
\text { Gasoline }\end{array}$ \\
\hline 945 & Vehicle Miles of Travel Has Reached New Highs & 946 & $\begin{array}{l}\text { Driving Alone in a Private Vehicle is the Most } \\
\text { Common Means of Transportation to Work }\end{array}$ \\
\hline 947 & $\begin{array}{c}\text { Over Half a Million Plug-in Vehicles Have Been Sold in } \\
\text { the United States as of September } 2016\end{array}$ & 948 & $\begin{array}{c}\text { Carbon Dioxide Emissions from Transportation } \\
\text { Exceeded those from the Electric Power Sector for } \\
\text { the First Time in } 38 \text { Years }\end{array}$ \\
\hline 949 & $\begin{array}{c}\text { Reduced CO2 Emissions in the Electric Power Sector } \\
\text { Will Benefit the Transportation Sector as } \\
\text { Electrification Grows }\end{array}$ & 950 & $\begin{array}{l}\text { Well-to-Wheel Emissions from a Typical EV by State, } \\
\qquad 2015\end{array}$ \\
\hline 951 & $\begin{array}{c}\text { Medium and Heavy Trucks Account for About a } \\
\text { Quarter of Highway Vehicle Fuel Use }\end{array}$ & 952 & $\begin{array}{c}\text { NHTSA and EPA Finalized Medium and Heavy Truck } \\
\text { Fuel Efficiency and Greenhouse Gas Standards } \\
\text { through Model Year } 2027\end{array}$ \\
\hline 953 & $\begin{array}{c}\text { On-road Transportation Consumes More than } 80 \% \text { of } \\
\text { all Transportation Energy }\end{array}$ & 954 & $\begin{array}{c}\text { Gasoline Taxes in the United States Were Below 20\% } \\
\text { of the Total Price in } 2015\end{array}$ \\
\hline 955 & New Light Vehicle Fuel Economy at an All-Time High & 956 & $\begin{array}{l}\text { Thirty-four Percent of Light Vehicles Produced in } \\
\text { Model Year } 2016 \text { were Sport Utility Vehicles }\end{array}$ \\
\hline 957 & $\begin{array}{l}\text { List of the Top Ten Most Fuel Efficient Light Vehicles, } \\
\text { Model Year } 2017\end{array}$ & 958 & $\begin{array}{c}\text { Sixty-three Percent of All Housing Units have a Garage } \\
\text { or Carport }\end{array}$ \\
\hline 959 & Record Light Vehicle Sales in 2016 & 960 & $\begin{array}{l}\text { Electricity and CNG Fuels had the Lowest Price } \\
\text { Variability Over the Past } 16 \text { Years }\end{array}$ \\
\hline 961 & $\begin{array}{l}\text { Alternative Fuel Corridors Established by the Federal } \\
\text { Highway Administration }\end{array}$ & 962 & $\begin{array}{c}\text { Vehicles per Capita: Other Regions/Countries } \\
\text { Compared to the United States }\end{array}$ \\
\hline 963 & $\begin{array}{c}\text { Share of Petroleum Product Output from Refineries } \\
\text { Varies by World Region }\end{array}$ & 964 & $\begin{array}{c}\text { Motor Gasoline Is Most Common Petroleum Product } \\
\text { from U.S. Refineries }\end{array}$ \\
\hline 965 & $\begin{array}{l}\text { The United States Produced More Petroleum than } \\
\text { Any Other Country in } 2015\end{array}$ & 966 & $\begin{array}{l}\text { Production of Petroleum in the United States was at } \\
\text { an All-time High in } 2015\end{array}$ \\
\hline 967 & $\begin{array}{c}\$ 500 \text { to } \$ 3,850 \text { : Wide Range for Model Year } 2017 \\
\text { Estimated Annual Fuel Costs }\end{array}$ & 968 & $\begin{array}{l}\text { All-electric Vehicles Have the Lowest Estimated } \\
\text { Annual Fuel Cost }\end{array}$ \\
\hline 969 & $\begin{array}{l}\text { New Vehicle Fuel Economy Has Improved 33\% From } \\
1980 \text { to } 2016\end{array}$ & 970 & $\begin{array}{l}\text { Eleven Percent of Motor Vehicles Jobs Focus on } \\
\text { Alternative Fuel and Advanced Technology Vehicles }\end{array}$ \\
\hline 971 & $\begin{array}{l}\text { Production and Manufacturing Comprise One-Third of } \\
\text { Motor Vehicles Jobs }\end{array}$ & 972 & $\begin{array}{l}\text { Thirteen Percent of Vehicles Worldwide are Produced } \\
\text { in the United States }\end{array}$ \\
\hline 973 & $\begin{array}{l}\text { Truck Stop Electrification Services to Reduce Idling } \\
\text { Are Available in } 35 \text { States }\end{array}$ & 974 & Plug-in Vehicle Sales Increased 40\% in 2016 \\
\hline 975 & $\begin{array}{c}\text { Nearly } 60 \% \text { of All-electric Vehicle Sales in } 2016 \text { Were } \\
\text { Large Cars and Standard SUVs }\end{array}$ & 976 & $\begin{array}{l}\text { China has Highest Number of Sales of Plug-in } \\
\text { Vehicles in the World }\end{array}$ \\
\hline 977 & $\begin{array}{c}\text { Nearly One-Quarter of Vehicles Sold in Norway are } \\
\text { Plug-in Vehicles }\end{array}$ & 978 & New Technology Penetration in Light Vehicles \\
\hline 979 & $\begin{array}{c}\text { More than One-Third of New Transmissions in } 2016 \\
\text { Had a High Number of Gears }\end{array}$ & 980 & $\begin{array}{c}\text { Use of Lightweight Materials Has Increased in the } \\
\text { Last } 20 \text { Years }\end{array}$ \\
\hline 981 & $\begin{array}{c}\text { Using a Cargo Box on Top of a Vehicle Can Reduce } \\
\text { Fuel Economy by } 25 \%\end{array}$ & 982 & $\begin{array}{l}\text { Slow Down to Save Fuel: Fuel Economy Decreases } \\
\text { About 14\% When Traveling at } 70 \mathrm{mph} \text { Versus } 60 \mathrm{mph}\end{array}$ \\
\hline 983 & Proper Tire Pressure Saves Fuel & 984 & $\begin{array}{l}\text { It is More Efficient to Stop and Restart a Vehicle's } \\
\text { Engine than to Idle for as Little as Ten Seconds }\end{array}$ \\
\hline 985 & $\begin{array}{l}\text { Average Historical Annual Gasoline Pump Price, } \\
\qquad 1929-2016\end{array}$ & 986 & $\begin{array}{c}\text { The Price of a Barrel of Crude Oil in } 2016 \text { Was the } \\
\text { Lowest Since } 2003\end{array}$ \\
\hline 987 & What Do We Pay for in a Gallon of Gasoline? & 988 & $\begin{array}{l}\text { The Average Price of a New Light Vehicle was Nearly } \\
\qquad \$ 32,000 \text { in } 2016\end{array}$ \\
\hline 989 & $\begin{array}{l}\text { The Most Common Price Point for Light Vehicles Sold } \\
\text { in } 2016 \text { was } \$ 27,000\end{array}$ & 990 & $\begin{array}{l}\text { Comparison of Vehicle Efficiencies Using the Air } \\
\text { Conditioner versus Windows Down }\end{array}$ \\
\hline 991 & $\begin{array}{c}\text { By Mode of Transportation, Freight Tonnage and } \\
\text { Freight Value Show Different Trends }\end{array}$ & 992 & $\begin{array}{l}\text { Motor Vehicles Are One of the Most Valuable } \\
\text { Commodities Shipped in the United States }\end{array}$ \\
\hline 993 & $\begin{array}{c}\text { By Value, Nearly Three-Fourths of Imports from } \\
\text { Mexico and More Than Half of Imports from Canada } \\
\text { are Transported by Truck }\end{array}$ & 994 & $\begin{array}{l}\text { Electric Vehicle Charging Consumes Less Energy than } \\
\text { Water Heating in a Typical Household }\end{array}$ \\
\hline 995 & $\begin{array}{l}\text { Electric Vehicle Charging at Home Typically Draws } \\
\text { Less Than Half the Power of an Electric Furnace }\end{array}$ & 996 & $\begin{array}{c}\text { Transportation Accounts for Nearly Three Quarters of } \\
\text { Petroleum Consumption }\end{array}$ \\
\hline 997 & $\begin{array}{l}\text { Average Age of Cars and Light Trucks Was Almost } 12 \\
\text { Years in } 2016\end{array}$ & 998 & $\begin{array}{c}\text { Highway Vehicles Responsible for a Declining Share } \\
\text { of Pollutants }\end{array}$ \\
\hline 999 & $\begin{array}{l}\text { Despite Rise in Vehicle Miles of Travel, Highway } \\
\text { Pollutants in } 2016 \text { Are Less Than Half as in } 2002\end{array}$ & 1000 & $\begin{array}{l}\text { U.S. Petroleum Production Met Demand from } \\
\text { Transportation Petroleum Consumption in } 2015\end{array}$ \\
\hline
\end{tabular}




\section{References}

ACEA (European Automobile Manufacturers Association), 2017. Share of Diesel in New Passenger Cars. Accessed September 29, 2017. http://www.acea.be/statistics/tag/category/share-of-dieselin-new-passenger-cars

Davies, Jason, 2017. Word Cloud Generator. Accessed October 3, 2017. https://www.jasondavies.com/wordcloud/

DOE (U.S. Department of Energy), 2016a. Fifteen Percent of Survey Respondents Consider Fuel Economy Most Important when Purchasing a Vehicle. September 16, 2016. https://energy.gov/eere/vehicles/fact-942-september-12-2016-fifteen-percent-survey-respondentsconsider-fuel-economy

DOE (U.S. Department of Energy), 2016b. On-road Transportation Consumes More than 80\% of all Transportation Energy. November 28, 2016. https://energy.gov/eere/vehicles/fact-953november-28-2016-road-transportation-consumes-more-80-all-transportation

DOE (U.S. Department of Energy), 2017a. Average Historical Annual Gasoline Pump Price, 19292016. July 10, 2017. https://energy.gov/eere/vehicles/articles/fact-985-july-10-2017-averagehistorical-annual-gasoline-pump-price-1929-2016

DOE (U.S. Department of Energy), 2017b. New Vehicle Fuel Economy Has Improved 33\% From 1980 to 2016. March 20, 2017. https://energy.gov/eere/vehicles/fact-969-march-20-2017-newvehicle-fuel-economy-has-improved-33-1980-2016

DOE (U.S. Department of Energy), 2017c. U.S. Petroleum Production Met Demand from Transportation Petroleum Consumption in 2015. October 23, 2017.

DOE (U.S. Department of Energy), 2017d. Transportation Fact of the Week. Accessed September 29, 2017. https://energy.gov/eere/vehicles/transportation-fact-week

EIA (Energy Information Administration), 2017a. Annual Energy Outlook 2017, with projections to 2050. Report DOE/EI-0003. https://www.eia.gov/outlooks/aeo/pdf/0383(2017).pdf

EIA (Energy Information Administration), 2017b. Monthly Energy Review. Accessed September 29, 2017. https://www.eia.gov/totalenergy/data/monthly/

EPA (U.S. Environmental Protection Agency), 2016. Light-Duty Automotive Technology, Carbon Dioxide Emissions, and Fuel Economy Trends: 1975 through 2016. Report EPA-420-R-16-010. https://www.epa.gov/fueleconomy/trends-report

FHWA (Federal Highway Administration), 2017. Highway Statistics 2015: Annual Vehicle Distance Traveled in Miles and Related Data - 2015. January 2017. https://www.fhwa.dot.gov/policyinformation/statistics/2015/vm1.cfm

Internet Archive, 2017. Internet Archive Wayback Machine. Accessed September 29, 2017. https://archive.org/web/

Kubik, M., 2006. Consumer Views on Transportation and Energy (Third Edition). Report NREL/TP620-39047. https://www.nrel.gov/docs/fy06osti/39047.pdf

Singer, Mark, 2015. Consumer Views on Transportation and Advanced Vehicle Technologies. Report NREL/TP-5400-64840. https://www.nrel.gov/docs/fy15osti/64840.pdf 